\section{AHMET KARTAL*}

Ö Z E T

Selçuklu hükümdarı Alp Arslan'ın 1071 tarihinde Malazgirt'te Bizansliları bozguna uğratmasılyla, Anadolu'nun Türkleşmesi ve İslâmlaşmasının uzun süreci başlamıştır. Malazgirt zaferini müteakip Anadolu'ya gelen Ŏ̆uz kitleleri, "dâru'l-cihâd" saydıkları Anadolu'yu Türkleştirmek ve İslâmlaştırmak için dinden aldıkları güçle savaşmışlar, Anadolu'nun derinliklerine kadar ilerleyerek, kendileri ile beraber, Türk dilini, kültürünü, örf ve idaresini de götürmüşlerdir. Artık Anadolu'nun bir Türk yurdu olmasının gayretleri içerisine girilmiştir. Bu yazının amacı, böyle bir ortamda Anadolu'da dil ve edebiyatin hüviyetini ortaya koymaktır.

A N A H T A R K E L İ M E L E R

Anadolu Selçuklu Devleti, dil, şiir, şâir, edebiyat.

\section{Anadolu Selçuklu Devleti Döneminde Dil ve Edebiyat}

Tongue and Literature in the Period of Anatolian Seljuk State

Selçuklu hükümdarı Alp Arslan (1063-1072)'in Malazgirt'te 1071 y1lında Bizanslıları bozguna uğratması neticesinde Anadolu baştan başa istilaya ve sürekli yerleşime açılmış, Anadolu'nun Türkleşmesi ve İslâmlaşmasının uzun süreci başlamış (Itzkowitz 1997: 27), bütün Ön Asya'nın, Selçuklular tasarrufuna geçmesi sağlanmıştır (Caferoğlu 1972: 3). Kaynaklar Horasan'da Selçuklu Devleti kurulduğu zaman Türkistan'dan İslâm ülkelerine olan göçü nasıl "sel" gibi tasvir etmişlerse 1071 Malazgirt zaferini müteakip Anadolu'ya akan insan dalgalarını da aynı

\footnotetext{
* Prof. Dr., Kırıkkale Üniversitesi Fen-Edebiyat Fakültesi Türk Dili ve Edebiyatı Bölümü, Kırıkkale. (ahmetkartal38@gmail.com)
} 
şekilde aksettirmişlerdir (Turan 1998: 282) ${ }^{1}$. Anadolu'ya gelen bu Oğuz kitleleri, dâru'l-cihâd saydıkları Anadolu'yu Türkleştirmek ve müslümanlaştırmak için dinden aldıkları güçle savaşmışlar (Mazıoğlu 1972: 297), Anadolu'nun derinliklerine kadar ilerleyerek, kendileri ile beraber, Türk dilini, kültürünü, örf ve idaresini de götürmüşlerdir. Bütün Anadolu Türklerin eline geçtikten sonra, Türk boyları ve halkları, eski Orta Asya bozkır geleneklerinden ayrılarak yeni yerleşik hayat prensiplerine yaklaşmak durumunda kalmışlardır (Caferoğlu 1972: 3-4). Türkmen de denilen bu Oğuzların bir kısmı yeni yurtlarında şehirlerde yerleşmişler, çoğu ise Anadolu'nun issız topraklarında yeni köyler kurmuşlar, ya da göçebe hayatını sürdürmüşlerdir (Mazıoğlu 1972: 297). Bu çalışmada, artık bir Türk yurdu hâline gelen Anadolu'daki dil, edebiyat ve kültürel faaliyetler hakkında bilgi verilecektir.

\section{Şiir ve Toplum}

Anadolu halkı özellikle şiirin ahengi ile veznin ritmik tekrarının insan ruhunda oluşturduğu etkiden dolayı, şiire karşı bir temayül sergilemiş, hatta kendisine aktarılacak her bilginin manzum olarak verilmesini istemiştir. Tabii ki bunda, şiirin öğrenmeye sağladığı katkı ve kolaylı̆̆ın bilincine vararak öneminin farkına varılması ve bundan yararlanma yoluna gidilmesi de etken olmuş olabilir. Şiiri seven ve ona sempati ile bakan halkın isteğiyle şiir, Anadolu'da uygun bir ortamla buluşmuştur. Şâirler bulmuş oldukları bu müsait ortamı en iyi şekilde kullanarak, şiirin Anadolu'da oluşması, gelişmesi ve yerleşmesi noktasında hummalı bir gayret içine girmişlerdir. Hatta şiirle ilgisi olmayanlar da, Mevlânâ gibi, şiir söylemeye meyil etmişler, duygularını ve düşüncelerini şiirle ifade etme yoluna gitmişlerdir. Şâirler, şiiri bir yandan toplumu, özellikle halkı eğitme, aydınlatma ve bilgilendirmenin bir vasıtası olarak kullanırken, diğer yandan belli bir bilgi birikimine sahip

\footnotetext{
${ }^{1}$ Bir anonim Bizans kroniği: kara ve deniz sanki bütün dünya kafir barbarlar (Türkler) tarafından işgal edildi ve ıssızlaştırıldı. Onlar şarkın (Anadolu'nun) bütün köylerini, evleri ve kliseleriyle birlikte, yağma ve istila ettiler ifadesiyle durumu açıça, ancak hissî olarak tasvir eder. Başka bir kronik Türklerin Anadolu'ya, eskisinden farklı olarak, artık bir yağmacı değil işgal ettikleri bölgelerin hakiki sahibi olarak sıfatıyla girdiklerini belirterek daha isabetli bir görüşü temsil eder (Turan 1998: 282).
} 
olup 'hakikati' 'hakikatin diliyle' öğrenenlerin estetik duygularına cevap veren bir araç olarak görmüşlerdir. Böylece toplumun her kesimine hitap eden ve onların ihtiyaçlarına cevap veren şiirler kaleme alınmıştır. Özellikle doğum yeri olan Belh insanının daha çok nesire temayül ettiğini ve şâirliğe dolayısıyla şiire çok önem vermediğini belirten Mevlânâ'nın, eğer orada kalsaydı, büyük ihtimalle kendisinin de o bölge insanının yolunda gideceğini, yani ders takrir eden, vaaz veren birisi olarak kalacağını, fakat Anadolu'ya geldiğinde buranın insanlarının arzusu doğrultusunda sahip olduğu hakikatleri vezinli bir şekilde yani şiirle ifade etmeye meylettiğini gösteren şu sözleri, Anadolu halkının bu durumunu göstermesi bakımdan önemlidir:

"Benim bir mizacım var, kimsenin benden incinmesini istemem. Yanıma gelen dostlar benden mütemadiyen şiir istiyorlar, yoksa şiir nerde, ben nerde. Vallahi ben şiirden usanm1şım, benim indimde şiirden aşağı bir şey yok. Benim şiir söylemem, misafir arzu ediyor diye ev sahibinin onları memnun etmek için işkembeyi eliyle yıkayıp temizlenmesine benzer. Çünkü misafirin canı işkembe çorbası istiyor. İnsan bir memlekette hangi mal revaçta ise, bayağı bir şey bile olsa, onu alıp satmalıdır. Bizim memleketimizde şâirlik kadar ayıp bir iş yoktu. Eğer memleketimde kalsaydım, ben de oranın âdetlerine uyar; vaaz etmek, ders okutmak ve kitap yazmakla uğraşırdım. Ama Allah böyle istedi, ben ne yapabilirim? Benim yaptığım, bir hekimin ilaçtan bıkıp onu içmek istemeyen, canı şerbet çeken bir hastaya ilacı şerbete karıştırarak vermesine benzer." (Kılıç 2007: 69)

\section{Şiir ve Sultanlar}

Sultanlar, isimlerinin baki kalabilmesi için şâirler tarafından söylenilen şiirlerin en önemli vasıtalardan biri olduğuna inandıkları için, Anadolu Selçukluları'nda da aynen Karahanlı, Gazneli ve Selçuklu saraylarında olduğu gibi, şâire büyük önem verildiği görülmektedir. Nitekim iki önemli kaynak eserden Çehâr Makâle (Semerkandî 1368: 62-63) ve Râhatü's-sudûr ve Âyetü's-sürûr'da (Râvendî 1999: I/61) zikredilen bilgiler ile Balasagunlu Yûsuf tarafından 1069/1070 yılında yazılan ve Türkçenin en önemli eserlerinden biri olan Kutadgu Bilig'in başlarında yer 
alan Buğra Han övgüsündeki bölüm (Arat 1979: 28) ve Ögdülmiş’in Odgırmış'a şâirlerle münasebet hakkında söylediği fikirler (Arat 1988: 318) bu durumu açık bir şekilde ortaya koymaktadır. Fahreddîn Behrâmşâh'ın Nizâmî-i Gencevî'ye Mahzenü'l-esrâr'ına karşılık verdiği hediyelerden sonra, yanındakilere söylediği şu sözler, bu düşüncenin Anadolu'da da devam ettiğini göstermektedir: "Ĕ̆ger şiir başarılı olursa, hazineler ve defineler bağışlarım. Çünkü bu manzum kitapla benim adım bu fani dünyada ölümsüz olarak kalacak. Bu fani dünyada ve geçici âlemde unutulmadan kalmak ve ismin ebedî olarak anılması, çok büyük bir itibar ve ulaşılması zor bir başarıdır." (İbn Bîbî 1996: I/92). Behramşah'ın şu ifadeleri de bunu destekler mahiyettedir: "Ĕğer Firdevsî bu kitabını (Şeh-nâme) yazmasaydı, o devrin padişahlarımı, taç sahiplerini, ünlü pehlivanlarını kim hatırlayacaktı? Adlarını kim ă̆zına alacaktı?" (İbn Bîbî 1996: I/93).

\section{Şiirin Dili}

Türkler Anadolu'ya gelip yerleşmeden önce, Anadolu'da Rumlar, Ermeniler, Süryaniler, Franklar, Yakubiler vs. yaşamaktaydı (Ocak 2006: 443; 2006a: 253). Türklerin Anadolu'ya gelmesi ve yerleşmesi iki safhada gerçekleşmiştir. Bunlardan birincisi, Malazgirt Savaşının akabinde Türkler kitleler halinde Anadolu'ya akın etmişler ve yerleşmişlerdir. Bunlar içerisinde göçebelerin yanında, daha Orta Asya'da iken yerleşik hayata geçerek şehirlerde yaşayan Müslüman Türkler de bulunmaktaydı. Bunlar, Anadolu'daki şehirlere yerleşmişler ve oralarda mesleklerini icra etmeye devam etmişlerdir. Daha bu dönemlerde bile bu Müslüman Türkler yerli Hristiyan nüfusa oranla Anadolu'da büyük bir çoğunluğa ulaşmışlardır. İkinci safha ise, Moğol istilasının başlamasıyla birlikte, Mâverâünnehr, Hârezm, Âzerbaycan ve Errân mıntıkalarından oluşan yoğun göçlerin oluşturduğu dönemdir. I. İzzeddîn Keykâvus ve I. Alâaddîn Keykubâd devirlerine rastlayan bu dönemde de, pek çok şehirli Türk, göçebe Türk nüfusla birlikte Anadolu'ya gelmiştir (Ocak 2006: 447). Özellikle Türkler Anadolu'da yeni kasaba ve şehirler kurdukları gibi, eski Bizans şehirlerini kendilerine uygun hale de getirmişlerdir (Baykara 2006: 291). Türklerle birlikte İranlıların da Anadolu'ya geldikleri görülmektedir. Daha çok tüccar, ilim adamı, şeyh ve müritlerden oluşan İranlılar, ekseriyetle şehirlere yerleşmişlerdir (Bayram 2001: 63). 
Bu manzara Anadolu'nun dolayısıyla Anadolu Selçuklu Devleti'nin hem karışık kültürlerden oluştuğunu hem de çok dilli bir ortam sunduğunu göstermektedir. Nitekim İbn Bîbî, Anadolu'da halkın beş dil konuştuğunu belirtir (1996: I/97). Osman Turan'a göre bu diller Türkçe, Farsça, Rumca, Ermenice ve Süryanicedir (Turan 2006: 471). Ancak İbn Bîbî'nin bir başka yerde Anadolu'nun dilinin Arapça ve Farsça olduğunu kaydetmesi (1996: I/141) Arapçanın da dil olarak Anadolu'da kullanıldığını göstermektedir.

Bilindiği gibi Büyük Selçuklu Devleti'nde resmî dil olarak Arapça ve Farsça kullanılırken, medreselerde eğitim Arapça ile gerçekleştirilmiştir. Bütün münevverler hem Arapça hem de Farsça bilgisine sahiptiler. Büyük Selçuklu Devleti'nin bir kolu olan Anadolu Selçuklu Devleti'nde de doğal olarak bilim dili Arapça, resmî belge dili önce Arapça, daha sonra Farsça olmuştur. Ancak bürokraside birçok Fars dilli memurun bulunması, Önasya'da hissedilmeye başlanan Moğol baskısı yüzünden bir çok Fars dilli münevverin Anadolu'ya göç etmesiyle Farsçanın itibarı artmıştır (Develi 2006: 42-44). Hatta büyük merkezlerde yüksek tabakanın edebî dili olduğu gibi, Türkçenin yanında bir derece konuşma dili hüviyeti de kazanmıştır (Turan 2006: 471). XIII. asırda kaleme alınan bazı eserlerin "sebeb-i te'lîf (yazılış sebebi)" bölümlerinde "halkın Fars diline olan meyli'nden dolayı Farsça kaleme alındığı belirtilmiştir. Hayati Develi'nin de belirttiği gibi, söz konusu halktan kasıt, idarî ve entelektüel zümreler olmalıdır (Develi 2006: 44). Çünkü kırsal alanda yaşayan halk Türkçe konuşuyordu, dolayısıyla kendisine hitap eden eserin de Türkçe olmasını istiyordu. Nitekim Yunus Emre bu halka Türkçe ile hitap edecektir. Mevlânâ (Turan 2006: 471) ve oğlu Sultan Veled (Mansuroğlu 1950: 217 [dipnot 6]) Rumca bazı şiirler kaleme almışlardır.

Anadolu Selçukluları zamanında, aynen Büyük Selçuklular döneminde olduğu gibi yukarıda zikredilen dillerden Farsça hem resmî belge dili hem de edebî dil olarak kullanıldığı için telif edilen eserlerin büyük bir kısmının Farsça olduğu dikkat çekmektedir. Mikail Bayram, yaptığ kütüphane taramaları neticesinde, Anadolu Selçukluları zamanında, 230 küsur eser telif edildiğini, bunlardan 20 tanesinin müellifinin meçhul olduğunu, geriye kalan eserlerin 80 müellif tarafından yazıldığını belirttikten sonra, bu eserlerden 145'inin Farsça, 68'inin Arapça, 15'inin 
Türkçe olarak kaleme alındığını, birkaç eserin de Süryanice ve Ermenice olduğunu söylemektedir (Bayram 2004: 107). Bu manzara Anadolu Selçuklu Devleti'nin hem karışık kültürlerden oluştuğunu hem de çok dilli bir ortam sunduğunu göstermektedir. Bu da her topluma kendi diliyle hitap eden çeşitli eserlerin yazılmasına sebep olduğu gibi, çok dilli şiirlerin (mülemma) yazılmasına da zemin hazırlamıştır.

Elimizdeki verilere göre Anadolu Selçuklu Devleti döneminde şiirin dili başta Farsça olmak üzere Türkçe ve Arapça olmuştur. Nadiren Rumca ile de şiirler söylenilmiştir.

\section{İlmî ve Kültürel Durum}

Anadolu'da gerek Dânişmendliler gerekse Anadolu Selçukluları döneminde ilmî ve edebî faaliyetler önce saray muhitinde başlamış, arkasından bu faaliyetler II. Kılıç Arslan'ın oğullarının valilikleri döneminde şehirlerdeki şehzade muhitlerine de sirayet etmiştir. Özellikle sükun ve asayişin iyice sağlanmasıyla Anadolu'da hummalı bir içtimaî ve fikrî hareket kendini göstermiştir.

Anadolu'daki ilk ilmî faaliyetlerin 1071-1178 yılları arasında Sivas, Tokat, Amasya, Kayseri, Malatya ve civarlarında hüküm süren Dânişmendliler döneminde ve onların hüküm sürdüğü bölgelerde başladığı görülmektedir. Bu devletin kurucusu olan Melik Ahmed Gazi, Selçuklu ailesinin muallimi olan Dânişmend Ali Taylu'nun oğlu olup babası gibi bilge bir kişi olduğu için Dânişmend Gazi diye anılmakla birlikte, kurduğu devlete de Dânişmendiye denmiştir. Melik Ahmed Gazi, bir yandan yeni fetihlerle uğraşırken bir yandan da fethettiği bölgelerde yoğun bir kültürel faaliyette bulunarak ilmî çalışmalara zemin hazırlamıştır. Nitekim bugünkü bilgilerimize göre Anadolu'da telif edilen en eski eser olup Melik Ahmed Gazi'ye sunulan Keşfu'l-akabe'de: "O yüce zatı iltizam edenler çoğunlukla fâzıl ve filozoflardır. Dünyanın her yanından bilgin kişiler (ehl-i ukûl) o hazrete yöneldiler. Her biri ilmini yayması miktarınca itibar görüp, o hazretin cömertlik denizinden payların aldılar" şeklinde yer alan kayıt, Malazgirt Zaferi'nden kısa zaman sonra Dânişmendliler ülkesinde ilmî çalışmaların başladığını ve Melik Ahmed Gazi'nin birçok ilim ve fikir adamını himaye ederek çalışmalarına imkan sağladığını göstermektedir. Ayrıca Melik Ahmed Gazi'yi sahib-kıran diye zikreden 
Keşfu'l-akabe müellifi İbnü'l-Kemal, hem onun Rum, Ermen ve Şam (Suriye)'da gerçekleştirdiği fetihlerini dile getirmiş hem de bu yerlerde geniş bir kültürel faaliyet içerisinde bulunduğunu, "Rum, Ermeni, Şam memleketleri o sahib-kıranın varlı̆̆ının feyzi ile İslâm nuruyla bezendi" şeklinde ifade etmiştir. Dânişmendliler devleti emirlerinden Kastamonu fatihi, Emir Karatekin'in İbn Makula'nın el-İkmâl adlı eserini okuduğuna dair bir kaydın bulunması da, bu dönemde ilmî faaliyetlerin varlığını göstermektedir. Anadolu'da yer alan medreselerin en eskilerinin XII. asrın ilk yarısında ve Dânişmendliler zamanında Niksar, Tokat, Sivas ve Kayseri'de yapılması bu açıdan dikkat çeken diğer bir noktadır (Bayram 2003: 2-3).

Dânişmendliler, özellikle Tokat, Sivas, Amasya ve Çorum bölgelerinde daha yoğun bir kültürel faaliyet içinde bulunmuşlar ve buralara devletlerinin kültürel politikasını yerleştirmişlerdir. Böylece bu yöreler çok erken tarihlerde belli bir kültürel karakter kazandığı gibi, gösterilen bu yoğun millî ve dinî diyebileceğimiz faaliyetler neticesinde, buraların çok erken sayılacak tarihlerde Türkleşmesi ve İslâmlaşmasını da gerçekleştirmişlerdir. Gazilik mefkuresine, Türk kültürüne ve Türkmencilik ülküsüne büyük önem veren Dânişmendliler, bunu yerleştirmeye ve yaymaya da çalışmışlardır. Nitekim Melik Ahmed Gazi ve beraberlerindekilerin kahramanlıklarının anlatıldığ 1 Dânişmend-nâme (Akkaya 1954) bu kültürel anlayışın mahsulü olduğu gibi Dede Korkut Hikayeleri (Ergin 1989) de XIV. asırda yine bu yörede, Amasya'da derlenmiştir. Yine Anadolu'da ilk Türkçe eser yazma geleneği Amasya'da başlamıştır. Moğol iktidarına ve özellikle Pervâne Muînüddîn Süleymân'ın ağır baskılarına rağmen Dânişmend İli, bu millî karakterini ve kültürel hüviyetini uzun süre muhafaza etmiştir (Bayram 2003: 3-6).

Anadolu'nun Türkler tarafından fethedilmesinden önce Süryanîlerin elinde bulunan ve önemli bir kültür merkezi olan Malatya, Dânişmendliler döneminde de bu özelliğini muhafaza etmiştir. Malatya'nın Türklerin Anadolu'yu fethetmesinden sonra da, Kuzey Mezopotamya ve Suriye'den Anadolu'ya açılan ticaret yolu üzerinde bulunmasının etkisiyle daha erken sayılabilecek bir tarihte önemli bir ilim merkezi hâline geldiği görülmektedir. Özellikle Glyaseddin Keyhüsrev'in veziri Malatyalı Muhammed Gazi, Şeyh İzzeddin Ebu'1- 
kasım-1 Hammuî, Şeyh Ebu Tâhir Ahmed-i İsfahanî, Muhammed b. Ebu Bekr-i Tebrizî gibi İran asıllı kişiler Malatya'ya gelip yerleşerek burada faaliyet göstermişlerdir. Böylece burada İran kültürü ile Süryanî kültürü yeniden buluşmuş ve Sasanîler devrindeki ilmî ve fikrî hareket yeniden oluşmaya başlamıştır. İran millî kültürünün yeniden canlandırılmaya çalışıldığ1 Malatya, Selçuklular zamanında şehzadelerin eğitim gördükleri bir merkez hâline gelmiştir. Glyaseddin I. Keyhüsrev ve oğlu İzzeddin I. Keykâvus burada eğitim gören sultanlardandır. Bu Selçuklu sultanlarının eski İran şahlarının adlarını kullanmalarında Türk cihan hakimiyeti ülküsünün yanında Malatya ve çevresindeki İran kültürünün de etkisi bulunmaktadır. Ayrıca burada eğitim gören sultanların çok iyi Farsça bildikleri de müşahede edilmektedir. Türk kültürünü ülkelerinde yaymaya ve yerleştirmeye çalışan Dânişmendlilerin, 50 yıl yönetimlerinde kalan Malatya'nın kültürel yapısını değiştirememeleri dikkat çekmektedir (Bayram 2003: 7-8). Selçuklular zamanında, sultanlar muallimi diye anılan Malatyalı Şeyh Mecdüddîn İshak'ın da etkisiyle Malatya'da, İslâmî ilimler alanında yoğun bir faaliyet göze çarpmaktadır (bak. Bayram 2003: 9-10).

Tokat ve Malatya'nın Dânişmendliler zamanında iki önemli ilim ve fikir merkezi hâline gelmesi, Selçuklular döneminde bu iki şehrin şehzadelerin eğitim ve tahsil yeri olmasında etkili olmuştur. Selçuklular döneminde bu iki zihniyet kendi şehirlerinde yetişen şehzadeyi iktidara getirme gayreti içerisine girmiş ve bu yönde siyasî faaliyetlerde bulunmuşlardır. Bu dönem ümerası da, ya bu iki zihniyetten birine mensup ya da birini tercih etme durumunda kalmışlardır. Genellikle bu mücadelede Malatya'nın iktidarlar üzerindeki ilmî, kültürel ve siyasî ağırlığının daha etkili ve yönlendirici olduğu görülmektedir. Tokat ve civarında Türk kültürüne ve Türkmencilik ülküsüne büyük önem verilirken, Malatya'da İran unsuru ağırlıkta idi. İbnü'l-esîr, İranlı meşhur İşrakî filozof Şihâbeddîn-i Sühreverdî el-Maktûl (587/1237) olduğu anlaşılan bir filozofun, Rükneddîn Süleymanşâh'ın Tokat emiri olduğu sıralarda Tokat'a gittiğini ve Tokatlı bir bilgin (fakih) tarafından Süleymanşah'ın huzurunda tartaklandığı için Tokat'ı terk etmek zorunda kaldığını bildirmesi, İranî zihniyet ile Türk düşüncesinin çatışma durumunda olduğunun göstergesidir. Hatta Türkmen sufî Evhadüddîn-i Kirmânî (635/1237), Malatya'da kendisine hizmet edeceği bir yer tahsis edilmediği için ora- 
dan kırgın olarak ve bir daha dönmemek üzere ayrılmıştır. Yine Evhadüddîn-i Kirmânî ile Mevlânâ'nın hocası Şems-i Tebrizî arasındaki ihtilâf, Mevlânâ ve çevresi ile Ahi Evren Şeyh Nasireddin Mahmûd ve çevresi arasındaki ilmî, fikrî ve siyasî mücadeleler de bu iki kültürel çevre arasındaki ihtilaflarının uzantısıdır (Bayram 2003: 12-13).

I. Glyâseddîn Keyhüsrev, oğullarından I. İzzeddîn Keykâvus'u Malatya'ya, I. Alâaddîn Keykubâd 'i ise Tokat'a tahsil ve eğitim için göndermiştir. I. Alâaddîn Keykubâd, sultanlığı döneminde Anadolu'da Türkmencilik mefkuresini hakim kılmaya çalışmış, yüksek memurluklara Türk asıllı kimseleri atamıştır. Hatta bu dönemde Türkmen şeyhler, ilim ve fikir adamları himaye edilmiş, Ahi teşkilatı bütün Anadolu'ya yayılmış, şehirlerde belediye hizmetleri Ahilere gördürülmüştür. Alâaddîn Keykubâd, büyük oğlu II. Glyâseddîn Keyhüsrev'in zihniyet bakımından kendisine muhalif olan Malatya'daki çevrelerle irtibatını ve yakınlığını, İranî zihniyete yatkınlığını fark ettiğinden dolayı, daha sağlığında küçük oğlu İzzeddîn Kılıç Arslan'ı veliaht tayin etmiştir. Nitekim İran unsuruna dayanan II. Glyâseddîn Keyhüsrev'in iktidara gelişinin ilk yıllarından itibaren Türkmenlere karşı olumsuz bir siyasî tutum içerisine girdiği görülmektedir. Hatta saltanatının ilk yılında (635/1237) Eğridir'de yaptırdığı kervansarayın kitabesinde kendisi için söylenen "Türkmen (Havariç) ve Bagileri dağıtıp yok eden" sözü dikkat çekmektedir. Glyâseddîn Keyhüsrev'in tahta çıkmasında gösterdiği yararlılıklardan dolayı atabek olan Sadüddîn Köpek, Türkmen ve Ahileri devlet kademelerinden uzaklaştırarak İran asıllı kişileri yüksek mevkilere getirme gayreti içerisine girdi. Türkmen ve Ahiler Glyâseddîn Keyhüsrev'e ve onu iktidara getirenlere karşı ayaklanınca, iktidarına muhalif olan güçleri yok etme temayülü gösteren sultan atabeyi olan Sadüddîn Köpek vasıtasıyla Türkmen yanlısı ileri gelen devlet adamlarını teker teker öldürttü veya saf dışı etti. II. Gıyaseddîn Keyhüsrev, kendisini bir suikast ile öldürüp Selçuklu tahtını ele geçirme niyetinde olan Sadüddîn Köpek tehlikesini bertaraf ettikten sonra, yeniden iktidarına karşı olan Türkmen çevrelerle mücadeleye koyuldu. Birçok Türkmen fikir adamlarını katletti veya tutuklattı (Bayram 2003: 15-17).

Babailer İsyanı 1339'da pek çok siyasî, ekonomik ve dinî etkenin bir araya gelmesiyle, öncülügünü Baba İlyas ve halifesi Baba İshak'ın yap- 
tığı, göçebe ve yarı göçebe Türkmenlerin Anadolu Selçuklu yönetimine karş1 giriştiği harekettir (bak. Ocak 1996a: 35-51, 142-51). Amasya ve Tokat bölgesinde organize edilen ve devletin temelini sarsan Babaîler isyanının en önemli neticesi, Anadolu'nun Moğol istilasına maruz kalmasına zemin hazırlaması olmuştur. Nihayetinde Türk tarihinde çok önemli bir dönüm noktası olan Kösedağ yenilgisi alınmıştır.

Moğol istilâsından sonra, Türkmen ve Ahilerin mücadeleleri, Moğol emperyalizmine ve Moğollarla işbirliği içerisinde bulunan güçlere yönelmiş ve bu hareket bütün Anadolu'ya yayılmıştır. II. Gıyaseddin'in ölümünden sonra Anadolu Selçukluları'nın tanınmış devlet adamlarından Celâleddin Karatay (Tanyeri 1993), bu köklü rekabeti ve siyasî ihtilâfı bertaraf etse de, ölümünden sonra Türkmen çevrelerin desteklediği II. İzzeddîn Keykâvus ile İranlı unsurların desteklediği IV. Rükneddîn Kılıç Arslan arasında taht mücadelesi başlamıştır. Moğolların Anadolu'yu işgalinden sonra İranî zihniyeti temsil eden fikir adamları ve ümeranın Moğol yanlısı bir politika izlemelerinden dolayı İranlı yöneticilerden yana oldukları dikkat çekmektedir. Nitekim Moğolların desteği ile kardeşi II. İzzeddîn Keykâvus'u yenen IV. Rükneddîn Kılıç Arslan 1261 tarihinde Selçuklu tahtına geçti. Onun döneminde ülkenin yönetimi kendisini iktidara getiren Pervâne Muîniddîn Süleymân, Vezir Tâceddîn Mu'tez ve Sâhib Fahreddîn Ali'nin elindeydi. Bunlar sultanın fermanını da alarak Anadolu'da Türkmenlerin elinde bulunan medrese, tekke, işyeri gibi müesseseleri gasp ettikleri gibi birçok yörede Türkmenleri katliama tabi tutmuşlardır. XIV. asrın sonlarına kadar devam eden bu uygulama neticesinde Türkmenler kitleler hâlinde uç bölgelere ve Suriye'ye göç etmişlerdir (Bayram 2003: 18-19).

XII. asrın sonlarında Sultan II. Kılıç Arslan, Danişmendliler devletini ortadan kaldırarak Danişmendlilerin başkenti Tokat ve çevresini oğlu Rükneddin Süleymanşah'a verdi. Burada eğitim gören Rükneddin Süleymanşah da Danişmendoğlu Melik Ahmed Gazi gibi ilim sever, fazıl ve filozof bir kişiydi. Mutaassıp bir Şafiî olan İbnü'l-Esîr onun hak-

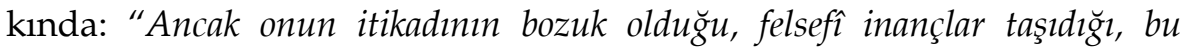
inançta olanların ona sığındı̆̆̆ı, ondan yardım ve himaye gördükleri nakledilir. Fakat o akıllı idi. Halkın tepkisinden çekindiği için bu inanç ve itikadını açı̆̆a vurmazdı" demektedir. Daha sonra Anadolu Selçuklu tahtına oturan 
Süleymanşah, Tokat ve çevresinde Dânişmendoğlu Melik Ahmed Gazi'nin başlattığı ilmî ve fikrî geleneği devam ettirmiştir. Yine İbnü’lEsîr, çeşitli mezheplere mensup ilim adamlarının onun huzurunda münakaşa ettiklerini kaydetmektedir (Bayram 2004: 123-24). İbn Bîbî ise görüşlerini aklına uygun ve tabiatına yakın bulduğu Şihâbeddin-i Sühreverdî'nin Pertev-nâme isimli eserini onun adına yazdığını bildirmektedir (I/44). Ancak Moğol istilâsı ile birlikte hem Tokat hem de Malatya'nın ilmî ve fikrî bakımdan sahip oldukları bu özelliklerini kaybederken, dönemin ünlü bazı filozoflarının, müderrislerinin ve âlimlerinin toplanmaya başladığı Anadolu Selçukluları'nın başkenti Konya'da bu açıdan bir canlanma olduğu dikkat çekmektedir. Nitekim bu dönemde kelâm ve mantığa dair Metâli'u'l-envâr ve Konya medreselerinde okuttuğu Beyânü'l-hak ve Kitâbu'l-menâhic adlı eserleriyle Kadı Sirâceddin-i Urmevî, mantık ve felsefe ile ilgili çalışmalarıyla Kadı İzzeddin-i Urmevî ve Şeyh Sadreddin-i Konevî ile zahir ve batın ilimlerinde zirveye ulaşan Mevlânâ Celâleddin-i Rumî Konya'da bulunan önemli simaları oluşturmaktaydı (Ay 1998: 83). Kayseri, Sivas, Amasya, Erzincan, Niğde, Kırşehir, Kütahya, Aksaray, Ankara, Kastamonu bu dönemde gelişme göstermiş diğer önemli kültür merkezleri olup her biri devlet ve hükümet merkezi olan Konya kadar gelişmişti (Köymen 1976: 363; Sümer 1963: 221).

Anadolu Selçuklu Devleti'nin kuruluşunu takip eden ilk 150 yıl (yaklaşık 616/1220'ye kadar) ve Danişmendliler döneminde Anadolu'da telif edilen eserlerin hemen hepsinin tıp, astronomi, matematik, felsefe gibi aklî ve tabiî ilimlere dair olduğu, âlimlerin de bu yönde faaliyet gösterdikleri görülmektedir. ${ }^{2}$ Anadolu'da görülen bu felsefe ve tabiî bilimlere yönelişin en önemli sebebi, ilk dönem Selçuklu Sultanları ile Danişmendli devlet adamlarının $\mathrm{Mu}^{\prime}$ tezile $^{3}$ eğilimli olmalarıdır. Selçuklu

\footnotetext{
${ }^{2}$ Bu dönemlerde Anadolu'ya gelip Kayseri'ye yerleşen Ömer b. Muhammed b. Ali es-Sâvî: "Diyâr-ı Rûm'a geldim. Herkesin ilm-i Nücûm (astronomi) ile uğraşmakta olduğunu, dinî ilimlerden bihaber olduklarını gördüm." diyerek bu gerçeği ifade etmiş ve dinî ilimlere olan ihtiyacı karşılamak amacıyla eserini yazdığını bildirmiştir (Bayram 2003: 59-60).

${ }^{3}$ Bilindiği gibi Mu'tezile mezhebi, İslâm'ın doğuşundan bir asır sonra ortaya çıkan, İslâm dinini akıl ölçü ve kurallarına göre yorumlayan dinî ve felsefî bir harekettir.
} 
hanedanına mensup kişiler ile bunlara yakınlığı olanlar arasında Mu'tezile eğilimli kişiler ile şehzadeler bulunmaktaydı. Gerek Eş'arî mezhebine mensup olan İbnü'l-Esîr'in ${ }^{4}$ Anadolu Selçuklu Devleti'nin kurucusu Süleymanşah'ın babası Kutalmış için, gerekse İbnü'1-Kemal'in ${ }^{5}$ astronomiye dair olan Keşfu'l-akabe isimli eserinin önsözünde Danişmend sultanı Melik Ahmed Gazi için söylediği sözler, bunu göstermektedir. Bu akliyeci geleneğin XIII ve XIV. asırlarda da Tokat ve çevresinde devam ettiğini İbnü's-Serrâc'ın 715/1315'te Kahta'da yazdığ1 Teşvîku'l-ervâh ve'l-kulûb isimli eserinden öğrenmekteyiz ${ }^{6}$ (Bayram 2003: 59-62). İbnü'l-adîm, Anadolu Selçuklu sultanı II. Kılıç Arslan'ın felsefî konulara ilgi duyduğunu ve bu konudaki ilmî tartışmalara katıldığını bildirmektedir. Suriye atabegi Nureddin Mahmud ise onu geniş anlayışı,

Zaten Mu'tezile'yi diğer mezheplerden ayıran en önemli özellik nakli yani Kur'ân ve Hadisi akla tatbik etmeleridir. Bundan dolayı bu mezhep mensuplarına İslâm dünyası rasyonalistleri (akliyecileri) denilmektedir. Bunlar üzerinde özellikle o dönemlerde İslâm âleminde yayılan Yunan felsefesinin büyük tesir görülmektedir. Abbasîler bir dönem Mu'tezile'yi resmî mezhep olarak kabul ettiler. Bu mezhep mensupları yüksek memurluklara tayin edilerek itibar görmüşlerdir. Ancak IV./X. asırda Eş'arî ve Maturidî mezheplerinin devlet tarafından desteklenmesi ve tasavvufî düşüncenin halk hareketi hâline dönüşerek rağbet kazanması sonucu Mu'tezile mezhebi geri plana itildi. Hatta Mu'tezile mezhebine mensup olanlarin halkı hor görmeleri ve kendi inançlarından olmayanları baskı altına almalarından dolayı sıkı bir takibata uğradılar (Bayram 2003: 60; Gölpınarlı 1979: 197-200).

${ }^{4}$ Eş'arî mezhebine mensup olan İbnü'l-Esîr, şu sözleriyle Kutalmış'in astronomi ve felsefe bilmesini tuhaf karşıladığını, bu felsefî bilgilerin özellikle onun dinî inancında yer tutmasını hoş karşılamadığını dillendirmiştir (Bayram 2003: 61): "Şaşılacak şeydir ki, Kutalmış, Türk olmasına rağmen astronomi ilmini çok iyi biliyordu. Bundan başka felsefe geleneği ile ilgili bilimleri de biliyordu. Kendisinden sonra oğulları ve ahfadı da felsefe geleneğinden gelen ilimleri öğrenmeye devam ettiler. Ve bu alanda isim yapmış olan bilim adamların himayelerine aldılar. Bu durum onların dinî inançlarında pürüz meydana getirdi."

${ }^{5}$ Aynen eniştesi Kutalmış gibi felsefe geleneğinden gelen ve bundan dolayı kendisine "Danişmend" de denilen Melik Ahmed Gazi hakkında İbnü'1-Kemâl şöyle demektedir (Bayram 2003: 61-62): "Pek çok filozoflar ve faziletli kişiler ve dünyanın dört bir yanından akliyeciler (ehl-i ukûl) o yüce zata yöneldiler ve her biri sahip olduklart ilimlerini yaymaları ve ilimlerini uyguladıkları ölçüde o Hazretin cömertlik denizinden pay almaktalar."

${ }^{6}$ İbnü's-Serrâc, Tokat ve çevresindeki alimlerin akla ve mantığa uymayan şeyleri kabul etmediklerini, bundan dolayı da dinî-tasavvufî düşünce ile evliya kerametlerini inkar ettiklerini belirterek bu yöre halkını eleştirmektedir (Bayram 2003: 62). 
hür düşünceye ve felsefeye olan temayülü sebebiyle zındıklıkla suçlamıştır (Turan 2002: 231-32). İşte hem Danişmendliler hem de Anadolu Selçukluları'nda bu felsefî ve ilmî geleneğin devam ettiği dönemlerde daha çok aklî ve tabiî ilimlere dair eserlerin yazıldığı dikkat çekmektedir.

$\mathrm{Bu}$ dönemde yani I. Alaaddin Keykubâd'ın cülûsuna kadar olan zamanda (616/1220) yazılan eserlerin en belirgin özelliklerinden biri ekseriyetle yerli olması (Ateş 1945: 133-34), bir diğeri de felsefe ile tabiî bilimlere ait eserlerin dinî ve tasavvufî eserlere nazaran daha çok olmasıdır. Nitekim Anadolu'da telif edilen ilk eser olan Keşfu'l-akabe (bak. Anadolu'da Yazılan İlk Eser), astronomi ve felsefeye dairdir. Şihâbeddîn-i Sühreverdî'nin Berkyaruk namina yazdığı Pertev-nâme'si de felsefeye aittir. Tiflisli Ebü'l-fazl Hüseyin Hubeyş b. İbrâhîm ibn-i Mehmed'in Arapçadan Farsçaya tercüme ettiği Usûlü'l-melâhim isimli fal kitabı, II. Kılıç Arslan adına yazdığı Kâmilü't-ta'bîr isimli rüya tabirnamesi ile astronomi ile ilgili olan Beyânu'n-nücûm isimli eserleri de gaybî ilimlere aittir. Tıbba dair ise Sthhatü'l-ebdân ile II. Kılıç Arslan'ın oğullarından Sivas valisi Kutbeddîn Melikşah adına yazdığ Kifâyetü't-tıb isimli eserleri vardır. Ayrıca Lügat ve emsile konusunda Kânûnu'l-edeb isminde bir eser daha kaleme almıştır. Bu eserlerin daha çok geniş bir okuyucu kitlesine hitap etmek için yazılmış oldukları dikkat çekmektedir.

Şihâbeddîn-i Sühreverdî, Farsça ve Arapça bir çok eser kaleme almıştır. Arapça eserler içersinde en önemlileri, İşrâkî felsefesinin tam bir dönemini ihtiva eden Hikmetü'l-işrâk, felsefe ve ilâhiyat ile ilgili etTelvîhât ile tamamen tasavvufî olan Heyâkilü'n-nûr (Sühreverdî 1988)'dur. Sühreverdî, felsefî konuları remiz ve işaretler yoluyla açıklayan Farsça mensur bazı eserler de kaleme almıştır. Âvâz-i Per-i Cibrîl, Kayseri'de telif edilen Bûstânu'l-kulûb, Erzincan veya Tokat'ta yazılıp Nasireddin Berkyaruk'a takdim ettiği Pertev-nâme, Risâle-i Lügat-i Mûrân, Risâle-i Sefîr-i Sîmurg, Mûnisu'l-uşşâk, Rûzî bâ Cemâ'at-i Sûfiyân, Risâle-i Akl-ı Sorh bunlardandır. Bu eserlerin üslûbunun çok akıcı ve sade oluşu dikkat çekmektedir. Temsilî olan eserlerin ekseriyeti hikâyeler şeklinde olup soru ve cevap ile birlikte ve basit bir tarzda yazılmıştır. Bunda hitap ettiği kesimin göz önünde bulundurulmuş olması etken olmuştur 
(Safâ 2002: 149). Sühreverdî, Arapça, özellikle de tasavvufî mahiyette yazdığı eserlerle bu dönemde dikkat çeken müelliflerdendir.

Bu dönemde Muhammed b. Gazî-i Malatyavî tarafından yazılan ve Marzubân-nâménin Farsçaya ilk tercümesi olan Ravzatü'l-ukûl, edebî mahiyette bir eser olmakla dikkat çekmektedir. Türü içerisinde oldukça başarılı bir şekilde yazılmış olan eser, Nasrullah b. Muhammed b. Hamîd'in Kelîle ve Dimne'si ve Zahîreddîn Kâtib-i Semerkandî'nin Sinbâd-nâme'si ile mukayese edildiğinde, onlardan hiç de geri olmadığ1 görülür. Ayrıca Marzubân-nâme'nin ilk tercümesi olması bakımından da önemlidir. Yine onun Berîdü's-sa'âde'si üslûbunun güzelliği ve hikâyecilikteki başarısını göstermektedir. Ravzatü'l-menâzır li'l-meliki'n-nâsır, Kemaleddin Ebu Bekr b. Sâ'idü'r-râdî tarafından Farsça olarak Nasireddin Berkyaruk namına yazılmıştır. Yirmi babdan oluşan eser, kelâma dairdir (Uzunçarşılı 1948: 292).

Bu dönemde, Râvendî́nin 599/1203'te başlayıp 603/1206 y1lında tamamlayarak Glyaseddin Keyhüsrev'e ithaf ettiği, Büyük Selçuklular ile İsfahan Selçukluları'ndan bahseden Râhatu's-sudûr ve Âyetü's-sürûr adlı tarihî eseri de (Râvendî 1333, 1999) dikkat çekmektedir. Fars nesrinin en güzel örneklerinden biri olan eser, hem sahip olduğu selaset hem de bir çok tarihî ve sosyal olaydan bahsetmesinden dolayı, Moğol saldırısından önce, VII/XIII. asrın en muteber kitaplarından sayılmaktadır.

I. Alâaddin Keykubâd'ın cülûsundan (616/1220) sonraki dönemde, Anadolu Selçukluları zamanındaki bu fikrî ve ilmî gelişme Moğol istilâsının etkisiyle, özellikle de Moğollar'ın 640/1243 yılında Anadolu Selçuklu Devleti'ni hakimiyetleri altına almalarından sonra, tedricen zayıflarken, dinî-tasavvufî düşünce ön plana çıııp gelişmeye başlamıştır. Çünkü XIII. asrın ilk çeyreğinden itibaren çok sayıda mutasavvıf ve sufî, Moğol istilâsından kaçarak huzur ve refahın mekanı olarak gördükleri Anadolu'ya gelmişler ve burada gösterdikleri faaliyetler neticesinde de, Anadolu'daki fikrî denge tasavvuf lehine bir ilerleme göstermiştir. Bunda Moğol iktidarının Anadolu halkı üzerinde yarattığ şiddetli fikrî ve siyasî baskı ile gerçekleştirdiği acımasız katliamlar neticesinde, çaresizliğe ve umutsuzluğa düşen Anadolu halkı için umut ve huzur kaynağ1 olan tekke ve zaviyelere rağbetin artması da etkili olmuştur. Böylece hızlı bir şekilde mistikleşmeye doğru giden Anadolu halkının pozi- 
tif ilimlere karşı olan ilgisi azalmaya başlamıştır. Ayrıca Moğolların Anadolu'da gerçekleştirdikleri bu katliam ve zulümlerden dolayı birçok münevver, kültürlü ve bilge kişiler ya öldürülmüş ya da Anadolu'yu terk etmişlerdir. Bu da doğal olarak Anadolu'daki ilmî faaliyetleri olumsuz yönde etkilemiştir (Bayram 2004: 134). Bu durum da doğal olarak dinî ve tasavvufî mahiyette eserlerin sayısının artmasına sebep olmuştur. Ayrıca burada insanları dinî yönden eğitme ve terbiye etme düşüncesinin de olduğu göz önünde bulundurulmalıdır.

$\mathrm{Bu}$ devrede Anadolu'da ekseriyetle Farsça olmak üzere Farsça, Arapça ve Türkçe yazılan dinî-tasavvufî-ahlâkî mensur eserlerin sayısında gözle görünür bir artış vardır. Nitekim Farsça olarak kaleme alınan Bahâeddîn Veled'in Ma'ârif (Furûzanfer 1352), Seyyid Burhâneddîn Muhakkık-i Tirmizî́nin Ma'ârif (Seyyid Burhaneddin Muhakkık-i Tirmizî 1972, 1995), Şems-i Tebrizî́nin Makâlât (Şems-i Tebrizî 1349, 1974-1975), Mevlânâ'nın Fîhi Mâ Fîh (Haşim 1333; Furûzanfer 1369; Gölpınarlı 1959; Anbarcığlu 1990; Konuk 1994) ve Mecâlis-i Seb'a (Tevfîk 1365; Gölpınarl 1965); Sultan Veled'in Ma'ârif (Anbarcığlu 1991); Baba İlyâs-1 Horasanînnin Cihâd-nâme (Bayram 2004: 67-72), Necmeddîn-i Dâye'nin Mirsâdü'l-ibâd mine'l-mebde' ile'l-me'âd (Riyâhî 1352) ve Sirâcu'lkulûb, Hacı Bektaş-1 Velî́nin Makâlât-ı Gaybiyye ve Kelimât-ı Ayniyye (Hacı Bektaş Velî 2004), Sa'îdüddîn-i Ferganî'nin Menâhicü'l-'ibâd ile'l-me'âd (Ateş 1945: 114) ve Şerh-i Kasîde-i Tâ'iye-i İbn-i Fâriz (Ateş 1945: 115-16), Fahreddîn-i Irâkî'nin Lema'ât (Şeyh Fahruddîn İbrahim-i Hemedânî 1373: 381-416; Fahrüddin Irâkî 1988) ve İstilâhât-i 'İrfâni-yi 'İrâkî (Şeyh Fahruddîn İbrahim-i Hemedânî 1373: 417-32), Sadreddîn-i Konevî̀nin Tabsıratü'l-mübtedî ve Tezkiretü'l-müntehî (Ateş 1945: 113-14), Ahi Evren'in Metâli'ü'l-îmân (Bayram 1996), Tabsıratu'l-mübtedî ve Tezkiretü'lmünteĥे, Mürşidü'l-kifâye, Yezdân-şinaht, Menâhic-i Seyfî ve Âgâz u Encâm'1, Arapça olarak yazılan İbn Arabî'nin el-Fütûhatü'l-mekkiyye (İbn Arabî 1405; Alpay 1986; Kılıç 1996), Fusûsü'l-hikem ve Husûsü'l-kilem (Konuk 1990), Fazl (Fezâ'il) Şehâdet el-Tevhîd ve vasf Tevhîd el-Mûkınî, Kitâb Hutbe fî-Keyfiyet Tertîb el-Âlem ve Şeklih, Kitâb Hilyet el-Abdâl, Tâc el-Terâcim fîİşârât el-İlm ve Letâ'if el-fehm, Kitâb el-Şevâhid, Kitâb el-Celâle ve Huve Kelimât Allah (Ateş 1952: 81-84), Sadreddîn-i Konevî'nin Nusus, Fükûk, Risâletü'l-vücûd, Miftâhu'l-gayb, Hacı Bektaş-1 Velî'nin Makâlât (Hac1 Bektaş Velî 1996), Yûsuf b. Ebî Said Ahmed-i Sicistânî́nin Münyetü’l- 
müftî ve Gunyetü'l-fukahâ (Özel 1990: 64)'s1 ile Türkçe telif edilen Hac1 Bektaş-1 Velî̀nin Şerh-i Besmele (Hacı Bektaş-1 Velî 1989)'si bunlardandır. Sipehsâlâr diye meşhur Ferûdûn b. Ahmed'in Mevlânâ hakkında kaleme aldığ 1 Risâle-i Sipehsâlâr be-Menâkıb-i Hazret-i Hudâvendigâr (Sipehsâlâr 1325, 1331, 1977) isimli Farsça bir menkabesi vardır. Muhammed b. Muhammed b. Mahmûd-1 Hatîb, Farsça Fustâtü'l-adâle fî-Kavâidi's-saltana (Riyâhî 1995: 126-28), Ahmed b. Sâd b. Mehdî-i Erzincanî ise, I. Alâaddîn Keykubâd adına Arapça Kitâbü'l-letâifü'l-alâiyye fi'l-fezâili's-seniyye (Uzunçarşılı 1948: 299) isminde bir siyasetname kaleme almıştır.

İnşa sanatı hakkında Hasan b. Abdü'l-mü'min-i Hoyî'nin Gunyetü'lkâtib ve Münyetü't-tâlib (Erzi 1963), Rüsûmü'r-resâ'il ve Nücûmü'l-fezâ'il (Erzi 1963a), Nüzhetü'l-küttâb ve Tuhfetü'l-elbâb, Kavâ'idü'r-resâ'il ve Ferâ'idü'l-fezâ'il (Terbiyet 1314: 113; Riyâhî 1995: 128-29), Emîr Bedreddîn Yahyâ'nın ise Münşe'ât-ı Bedreddin Yahyâ (Riyâhî 1995: 135-36) isimli eserleri dikkat çekmektedir. Mevlânâ'nın mektupları, Mektûbât (Mevlânâ 1335, 1937; Subhânî 1371; Gölpınarlı 1963), Ebu Bekir b. Zekî-i Konevî'ninkiler ise Ravzatü'l-küttâb (Ateş 1945:120-22) başlığ1 altında bir araya getirilmiştir.

$\mathrm{Bu}$ dönemde mantık ve hikmet alanında da eser verilmiştir. Mahmûd b. Ebî Bekr b. Ahmed-i Urmevî'nin Letâ'ifü'l-hikme (Yûsufî 1351) ve Metâli'u'l-envâr (Riyâhî 1995: 132-35; Terbiyet 1314: 180) isimli eserleri bunlardandır. Muhammed b. el-Hüseyn el-Mu'înî de Kur'ân'ın anlaşılmasını kolaylaştırmak için yazdığ1 Beşâirü'n-nezâ'ir (Ateş 1945: 112-13) isimli bir sözlük hazırlamıştır. Nasireddin-i Sicistânî, gizli ilimlere dair Dakâyiku'l-hakâyık'ı (Riyâhî 1995: 137), İbn Bîbî de Anadolu Selçukluları tarihi olan El Evamirü'l-ala'iye fi'l-umuri'l-ala'iye [Selçukname]'yi kaleme almıştır (İbn Bîbî 1996). Bu dönemde tabiî ilimlere ait bazı eserler de verilmeye devam edilmiştir.

\section{Şiir ve Şâirler}

Bugünkü bilgilere göre I. Alâaddîn Keykubâd'ın cülûsuna kadar olan zamanda (616/1220) yetişen şâir sayısının azlığ1 dikkat çekmektedir. Bunda devletin kuruluş aşamasında olması ve istikrarın tam oluşmaması etken olmuştur. Bu şâirlerin Farsça, Arapça ve Türkçe olarak söyledikleri bazı şiirleri günümüze kadar gelmiştir. Bu şiirlerin mesnevî, 
kaside ve rubaî formunda söylendikleri görülmektedir. Ancak bu nazım şekilleri içerisinde rubaînin belirli bir ağırlığının olduğu dikkat çekmektedir. Tiflisî́nin 2, II. Rükneddîn Süleymânşâh ile I. İzzeddîn Keykâvus'un bir rubaîsi vardır. Ancak bir yandan Bizans'a karşı mücadele ederken diğer taraftan çevresinde bir edebî muhit oluşturan Ankara Meliki Muhyiddîn Mes'ûd adına Ebu Hanîfe Abdülkerîm bin Ebûbekr tarafından tertip edilen El-İhtiyârât min-Mecma'i'r-rubâ'iyyât adlı mecmuanın bize ulaşan birkaç sayfasından Münteceb oğlu Bedî'-i Engüriyeî́nin 4, Muhyevî-i Engüriyeî́nin 6, Hekim Mahmûd-1 Engüriyeî'nin 1 rubaîsi ile karşılaşıyoruz. Ayrıca Anadolu'da yaşayıp şiir söyledikleri zannedilen Ali Unsâbâdî, Fahrî, İmâm Ali Hayşem ve Seyyid Eşref isimli şâirlerin de birer rubaîleri kayıtlıdır. Yine bu dönemde I. Giyâseddîn Keyhüsrev'in gurbete çıtığı sırada Rum ülkesinden Şam diyarına giden Şeyh Mecdüddîn İshak'1 Konya'ya davet etmek için yazdığı manzum mektup dikkat çekmektedir. Nasireddîn Berkyaruk'un İran efsanesine dayanan Hür-zâd ile Peri-nejâd hikâyesini son derece güzel, akıcı, sanatlı ve mükemmel bir şekilde Farsça olarak nazmettiği mesnevîsi ile bir rubaîsi bulunmaktadır. Yine bugün için kayıp olan Nizâmeddîn Ahmed-i Erzincanî, mesnevî formunda söylediği bir şehnâmesi vardır. Şihâbeddîn-i Sühreverdî, tasavvufî mahiyette Arapça şiirler kaleme aldığı gibi, İbn Sînâ'nın Arapça olarak kaleme aldığı Kasîde-i Rûhiye'sine de bir nazire yazmıştır. Râvendî ise Giyâseddîn Keyhüsrev'i övmek için yazmış olduğu bir kasidesi bulunmaktadır. Bu durum bize 616/1220 tarihine kadar Anadolu'nun özellikle kültür ve sanat alanında ne seviyede olduğunu göstermesi bakımından önemlidir. Hatta El-İhtiyârât minMecma'i'r-rubâ'iyyât adlı mecmuanın fihristinden o dönemde yazıldığ 1 anlaşılan kasideler, bize kadar ulaşmış olsa idi hem o dönemde yetişen daha çok şâiri tanımış olacaktık, hem de o dönem edebiyatı hakkında daha sağlıklı bilgiye sahip olacaktık.

Bu dönemin Türk dili ve edebiyatı açısından en önemli hususiyeti, Anadolu'da Türkçe olarak yazılan ilk manzum ve mensur eserlerin bu devre ait olmasıdır. Ayrıca bu eserlerin Türkmencilik ruhunun hakim olduğu, yoğun bir şekilde Anadolu'nun Türkleştirilmesi ve İslâmlaşt1rılması için millî ve dinî diyebileceğimiz faaliyetlerin sergilendiği Danişmendlilerin kurulduğu coğrafyada yazılması da dikkat çeken diğer bir noktadır. Anadolu'da yazılan ilk Türkçe eser tıp alanında iken, 
ilk Türkçe şiirin Anadolu'nun çeşitli yerlerinde özellikle büyük merkezlerinde gezerek orada bulunan halkı irşad etme mücadelesi veren Evhadiye tarikatının kurucusu Şeyh Evhadüddîn-i Kirmânî tarafından söylenmesi de önemlidir. Bu durumun Anadolu'da yaşayan Türklere hem yaşadıkları bu dünyada kendilerinin maddî ihtiyaçlarına cevap verecek bilgileri hem dinî vecibelerini tam ve doğru olarak yerine getirebilmeleri ve dinî hayatlarını tanzim edebilmeleri için dini, hem de gönül dünyalarını ihya ve mamur etmeler için de tasavvufu öğretme ihtiyacından kaynaklandığ1 görülmektedir. Ortaya konulan eserlerin dilini, hitap edilen kesimin belirlemesinden dolayı, artık Türk halkına kendi dilleriyle seslenilmeye başlanılmış ve Anadolu'da Türkçe ile söylenilen bir edebiyatın oluşmasına zemin hazırlanmıştır. İşte bu düşünceden hareketle verilmeye başlanan eserler, Anadolu coğrafyasında Türk dilinin mükemmel bir ilim ve edebî dil olma yolculuğunun başlangıcını teşkil etmiştir.

I. Alâaddîn Keykubâd'in cülûsundan (616/1220) sonraki dönemde, Anadolu Selçukluları zamanındaki bu fikrî ve ilmî gelişme Moğol istilâsının etkisiyle, özellikle de Moğollar'ın 640/1243 yılında Anadolu Selçuklu Devleti'ni hakimiyetleri altına almalarından sonra, tedricen zayıflarken, dinî-tasavvufî düşünce ön plana çıııp gelişmeye başlamıştır. Çünkü XIII. asrın ilk çeyreğinden itibaren çok sayıda mutasavvıf ve sufî, Moğol istilâsından kaçarak huzur ve refahın mekanı olarak gördükleri Anadolu'ya gelmişler ve burada gösterdikleri faaliyetler neticesinde de, Anadolu'daki fikrî denge tasavvuf lehine bir ilerleme göstermiştir. Bunda Moğol iktidarının Anadolu halkı üzerinde yarattığı şiddetli fikrî ve siyasî baskı ile gerçekleştirdiği acımasız katliamlar neticesinde, çaresizliğe ve umutsuzluğa düşen Anadolu halkı için umut ve huzur kaynağı olan tekke ve zaviyelere rağbetin artması da etkili olmuştur. Böylece hızlı bir şekilde mistikleşmeye doğru giden Anadolu halkının pozitif ilimlere karşı olan ilgisi azalmaya başlamıştır. Ayrıca Moğolların Anadolu'da gerçekleştirdikleri bu katliam ve zulümlerden dolayı birçok münevver, kültürlü ve bilge kişiler ya öldürülmüş ya da Anadolu'yu terk etmişlerdir. Bu da doğal olarak Anadolu'daki ilmî faaliyetleri olumsuz yönde etkilemiştir (Bayram 2004: 134). Bu durum da özellikle dinî ve tasavvufî mahiyette eserlerin sayısının artmasına sebep olmuştur. Ancak 
burada tabii ki, insanları dinî yönden eğitme ve terbiye etme düşüncesinin olduğunu da göz önünde bulundurulması gerekmektedir.

$\mathrm{Bu}$ dönemde gerek yetişen şâir sayısında gerekse ortaya konulan şiir sayısında olan artış da dikkat çekmektedir. Bunda şiire ve şâire sempati ile bakan ve onları destekleyen sultanlar ile devlet adamlarının da önemli etkisi olmuştur. Özellikle I. Alâaddin Keykubâd döneminde oluşan huzur ve refahın etkisiyle Anadolu'nun şâirler ve sanatkârlar için bir cazibe merkezi hâline gelmesi buna katkı sağlamıştır. Bu dönemde yazılan şiirlerin de ilk dönemde olduğu gibi ekseriyetle Farsça söylendiği dikkat çekmektedir. Bunda Orta Asya'da Türkler arasında hiçbir komplekse girmeden dönemin kültür ve medeniyet dili olan Farsça ile yazma âdetinin de etkili olduğunu göz önünde bulundurmamız gerekmektedir. Ancak Türkçe şiirlerdeki hem artış hem de söyleyişteki mükemmeliyet gözlerden kaçmamaktadır. Arapça şiirlerin söylenilmesine de devam edilmiştir. Bu dönemde yazılan şiirler mesnevî, kaside, gazel ve rubaî formunda karşımıza çıkmaktadır.

Farsça mesnevîler içerisinde, şüphesiz en çok takdir ve hayranlık uyandıranı Mevlânâ'nın 6 ciltlik Mesnevî̀- $i$ Ma'nevĩ sidir. Sultân Veled'in İbtidâ-nâme, Rebâb-nâme ile son mesnevîsi olan İntihâ-nâme, Kad1 Burhâneddîn-i Anevî'nin Enîsü'l-kulûb, Kâni-i Tûsî'nin Selçuklu Şeh-nâmesi ile Kelile ve Dimne Tercümesi, Nâsırî́nin Fütüvvet-nâme, Nasireddîn-i Sicistânî́nin Mûnisü'l-avârif ile Fahreddin-i Irâkî'nin Uşşâk-nâme'si bu dönemde kaleme alınan diğer mesnevîlerdir.

Bu dönemin dikkat çeken noktalarından biri de Farsça, Arapça ve Türkçe divanların tertip edilmesidir. Bunlar içersinde en dikkati çeken Mevlânâ'nın Dîvân-ı Kebîr'idir. Sultan Veled, Seyf-i Fergânî ve Fahreddîn-i Irâkî Farsça divanı olan diğer şâirlerdir. İbn-i Arabî'nin ise Arapça bir divanı bulunmaktadır. Rubaî de geçen asırda olduğu gibi rağbet gören nazım şekillerindendir. Mevlânâ, Sultan Veled, Evhadüddîn-i Kirmânî ve Fahreddîn-i Irâkî bu dönemde rubaî söyleyen şâirlerin önde gelenlerindendir.

$\mathrm{Bu}$ dönemde de geçen dönemde olduğu gibi Türkçe eserler verilmeye devam edilmiştir. Nitekim bu zamanda yaşayan Mevlânâ, Sultan Veled, Nâsırî ve Dehhânî́nin bazı Türkçe şiirlerinin olduğu bilinmektedir. XIII. asrın ortaları ile XIV. asrın başlarında yaşadığı tahmin edilen, 
Türkçe bir Dîvân tertip edip Risâletü'n-nushiyye (Tatçı 1990) adında bir mesnevî kaleme alan Yunus Emre'nin bu şâirler içerisinde müstesna bir yeri vardır.

\section{Şiir ve Tasavvuf}

Sûfî şâirler, günlük dilin sı̆̆ ve dar imkânları yanında aktarmak istedikleri yüce mânâya şiirsel dilin daha fazla imkân sağladığını görerek tercihen şiire yönelmişlerdir (Kılıç 2007: 70). Filibeli Ahmed Hilmî'nin de belirttiği gibi İran'da zuhur eden mutasavvıfların hemen hepsi şâirdir ve bunlar tasavvufî fikirlerini daha çok şiirle ifade etmişlerdir (Kılıç 2007: 34). Bu durumun Anadolu'da da yansimasinın hemen hemen aynı olduğu görülmektedir. Nitekim İhsan Fazlığlu'nun Anadolu'da da "irfan"ın şiirle hayat bulduğunu belirten şu sözleri bu mânâda dikkat çekmektedir (2006: 420):

"İrfanı̂ bilginin Varlık'la dolayımsiz yani önceden tayin edilmeyen bir dille ilişki kurması gerektiğini benimseyen, ancak sunumunda nazarî bir dil kullanan irfan-i nazarî okulun tersine hem Varlik'la alâkalı bilginin elde ediminde hem de sunumunda nazarî yöntemi reddeden tasavoufî yaklaşımlar, Yunan düşünce hayatındaki şâir ile filozof kavgasin hatırlatırcasına, şïr dilini benimsediler. Çünkü onlara göre burhanî bilgide matlub (yani kıyasin sonucu) hedef iken irfanî bilgide mahbîb (yani arzu edilen ya da Tanri) hedeftir. Bu kabul açısından burhanî bilgide matlub tahsil edilir; irfan̂̀ bilgide ise mahbuba vüsul esastır. Visalde ise ana tavur, ön-deyisiz yani herhangi kategorik bir dili benimsememek, başka bir deyişle çıkış noktası olarak almamaktır. Özellikle Mevlânâ Celâleddîn'de, daha sonra Yunus Emre'de göreceğimiz bu tavır özünde Varlı'’n yani Hakikat'in sırrm (cevherini) bilmeyi esas alan bütüncül bir dünya görüşü ve dünya tasavouru sunar. Bu noktada ilginç olan bir husus irfan-ı nazarînin kurucu isimlerinden Konevî̀nin babası Şeyh Mecdüddin İshak'ın, İzzeddîn Keykâvus (1211-1220) devrinde irfanî bilgiyi şiir diliyle ifade etmesidir. Bu nokta irfanî bilginin ifadesindeki farkh tavirlarm başta Konya olmak üzere Anadolu topraklarinda ne derece yaygin olduğunu gösterir. Gerçekten de Anadolu'da Varlık'la konuşulan bir dil olarak şiir her yönüyle gelişkindi". 
Türkler Gibb'in de ifade ettiği gibi tamamen işlenmiş ve organize edilmiş bir şekilde buldukları İran'ın tasavvufî-felsefî sistemî ile şiir sisteminin her ikisini de alıp hiçbir komplekse girmeden kullanmışlardır (Kılıç 2007: 33). Özellikle de Yûnus Emre tarafından bu dönemde adeta bir Türk tasavvuf ve istılah dili kurulmuş ve bunun mükemmel örnekleri verilmiştir (Tatçı 1990: I/67).

\section{Sultanlar ve Ödüller}

Anadolu Selçuklu sultanlarının yazdıkları şiirleriyle isimlerini bu fani âlemde baki kılan şâirlere verdiği bol ödül ve bahşişler çeşitli kaynaklarda zikredilmektedir. Meselâ, İzzeddin Keyhüsrev, Hüsameddîn Sâlâr'ın kızı tarafından kendisi için yazılarak Musul'dan gönderilen kasideye karşılık 7200 dinar göndermiştir. Ayrıca kasideyi getiren postacıya da hil'at, binek hayvanı ve iki bin dinar verilmiştir (İbn Bîbî 1996: I/142-7; geniş bilgi için bak. Kartal 2006: 495).

Sultanlar, bazen güzel bir şiirinden dolayı bazı şâirlere ya sarayda çeşitli görevler vermişler ya da derecelerini yükseltmişlerdir. Sultan I. Keykâvus, Sahib Şemseddin Muhammed-i İsfahânî́nin söylediği bir rubaî hoşuna gidince, onun mutfak sorumluluğu görevine (eşrâf-1 matbah), has kâtiplik (inşâ-yı hâs) görevini de eklemiştir (İbn Bîbî 1996: I/221). Şemseddin Tabas, Nizameddin Ahmed-i Erzincanî'nin yazdı̆̆1 bir kasideye, İzzeddin Keykâvus övgüsünde bir cevap yazınca, Sultan ona Rum memleketlerinin emîr-i arizlik ve inşa makamını (mertebe-i mansıb-ı inşâ-yi emîr-i arizi-yi memâlik-i Rûm) vermiştir (İbn Bîbî 1996: I/149; Köprülü 1986: 209).

\section{Şâirler ve Unvanlar}

Şâire ilgi ve itibarın bir tezahürü olan melikü'ş-şu'arâ unvanının Karahanlı, Gazneli ve Selçuklu saraylarında bulunan bazı şâirler için kullanıldığı gibi (Kartal 2001: 57) Anadolu Selçuklu sarayında bulunan kimi şâirlere de verildiği görülmektedir. Takrîru'l-menâsib'de yer alan bir menşur bunu doğrulamaktadır. Nitekim Muhiddîn Ebu'l-fezâ'il'in melikü'ş-şu'arâlığa tayinine dair olan bu menşurda, onun baba ve dedeleri zamanından beri saltanata mülâzemet ettiği ve bu vazifeye getirildiği, her defa sultanın meclisinde musahiplere fesahat ve belâgatını 
göstermesi, şiirleriyle gönüllere ferahlık vermesi, mübarek günlerde ve bayram merasimlerinde tebrik şartlarını takdimden sonra, güzel şiirler ve zarif sözlerle lâtif tabiatlı ve hassas kalpli olanlara tenezzüh bahşetmesi ve her şiirin sonunda devletin devamı için dua ibareleri koyması bildirilmektedir (Turan 1988: 57-58). Bu menşurda yer alan ibareler, aynı zamanda melikü'ş-şu'arâ'nın bizzat padişahın emriyle tayin edildiğini, görevlerinin ne olduğunu ve kendilerinden neler beklendiğini ortaya koyması bakımından da önemlidir. Anadolu Selçuklularında Muhiddîn'den başka Hüsâmeddîn (Turan 1988: 157-58), Nizâmeddîn Ahmed-i Erzincanî (İbn Bîbî 1996: I/147, 418) ve Bahâeddîn Kâni’̂̂ (Ahmet Eflâkî 1989: I/354) de bu makamda bulunan şâirlerdendir.

\section{Anadolu'da Yazılan İlk Şiir}

Bugünkü bilgilere göre Anadolu'da ilk şiir söyleyen kişi Kemâleddîn Hubeyş bin İbrâhîm-i Tiflisî́dir. Tiflisî, Anadolu'ya gelerek II. Kılıç Arslan'ın yakınları arasına girmiş, onun Malatya'da tertip ettiği dinî ve ilmî toplantılara katılmış ve muhtemelen 579/1183'te ölmüştür. Felsefe (hikmet), heyet ve nücum gibi ilimlerde maharet sahibi olan Tiflisî́nin Farsça iki şiiri günümüze kadar gelmiştir. Bunlardan orta dereceli bir şâir olduğu anlaşılan Tiflisî'nin Nüzhetü'l-mecâlis'te geçen bir rubaîsini Muhammed Emin Riyahî zikretmektedir (Riyâhî 1995: 55-57):

Senin yüzünde kendi yüzümü görmek mümkün. Kemiğin içinden iliğini görmek mümkün. Karanlıkta seni görmek o kadar kolay ki, hatta lutfundan dolayı bedeninde canın görmek mümkün.

\section{Anadolu'da Yazılan İlk Eser}

Bugünkü bilgilere göre Anadolu'da telif edilen ilk eser, Malazgirt Zaferi'nden 30 sene kadar sonra, Dânişmendoğulları'nın Kayseri Dizdarı olan İbnü'l-Kemâl İlyâs b. Ahmed'in Kayseri'de yazdığı ve Dânişmendoğulları Devleti'nin kurucusu Gümüş-Tigin Ahmed Gazi'ye sunduğu Keşfü'l-akabe (Bayram 1981) adlı astronomiye dair Farsça eserdir. Eserin mukaddimesinden anlaşıldığına göre asıl konusu felsefe yani hikmettir. Ancak müellif bazı metafizik düşünce ve görüşlerini astronomik gerçeklermiş gibi göstermek amacıyla, konuya giriş mahiyetinde coğrafî ve astronomik bilgiler de vermiştir. Dört makaleden oluşan 
eserin birinci makalesi, madde âleminin (âlem-i süflî) şekli ve yer kürenin hareketsiz olduğunun ve dört ana unsurun (toprak, hava, su, ateş) varlıklarının ispatı hakkında olup 13 fasıldır. İkinci makale, cennet ve cehennemin şekillerinin belirlenmesine dair olup iki fasıldır. Üçüncü makale, nefs-i nâtıkanın (insan ruhunun) mahiyeti, dördüncü makale ise nefs-i nâtıkanın saadet ve şekaveti hakkındadır. Özellikle bu eserde dünyanın yuvarlak olduğu hakkında ortaya konulan delillerin mükemmelliği, ay ve güneş tutulmasının şekillerle izahı, kuzey ve güney kutuplara gidildikçe gece ve gündüz farkının büyüdüğü, kutuplarda ise altı ay gece ve altı ay gündüz olup soğukluğun da en şiddetli olduğu, dünyanın çevre uzunluğu, yüzölçümü ve 1 derecelik meridyen arasındaki mesafe için verilen rakamların bugünkü ölçülere uygunluğu, dünyadaki iklim kuşakları ve kuşaklarda bulunan belde ve kavimler gibi bir çok konularda yer alan bilgiler insanı hayran bırakacak tarzdadır. $O$ dönemde Anadolu'daki astronomi ilminin kendi çağlarına göre yüksek bir düşünce seviyesinde bulunduğunu gösteren bu eser, her şeyden önce Türklerin Anadolu'da ilim ile uğraşıp eser yazma geleneğinin VI./XIII. asrın ikinci yarısından itibaren değil (Köprülü 1986: 208), bilakis bu asrın başlarından itibaren başladığını göstermesi bakımından önemlidir. Eserin dikkat çeken taraflarından biri de, Hz. Muhammed'in mi'rac olayının astronomik izahının yapılmaya çalışılmasıdır. Nitekim bazı metafizik meseleleri astronomik gerçekler olarak telakki eden İbnü'l-Kemâl, eserinin ikinci makalesinde, dünyayı tamamen kuşatan hava tabakasının yedi tabakadan oluşan bir ateş tabakası (ateş seması) ile çevrildiğini, bunun da Hz. Peygamber'in haber verdiği cehennem olduğunu, yine Hz. Peygamber'in haber verdiği cennetin de cehennem semasını çepeçevre kuşatan ve sekiz tabakadan meydana gelen sema (cennet seması) olduğunu ileri sürer. Eserinin üçüncü makalesinde insan ruhunun mahiyetini incelerken, dördüncü makalede bedenden ayrıldıktan sonra kalıcı olan ruhların şekaveti (cehennemde kalışları) ve saadeti (cennete yükselişleri) anlatmıştır. Bir nevi Hz. Peygamber'in mi'rac hadisesinin astronomik izahının yapılması gayretinden doğan bu tarz düşünüş ve anlayış, İslâm dünyasında hem bir seyr-i sülûk-i ruhanî, hem de edebî bir motif olmuştur. İşte İslâm dünyasında edebî bir motif olan bu tarz ve düşünceyi ilk defa başarılı bir şekilde Ebu'l-alâ el-Ma'arrî (449/1057), Risâletü'lgufrân isimli eserinde işlemiştir. Ebu'l-alâ el-Ma'arrî'den yaklaşık 45-50 
sene sonra, İbnü'l-Kemâl'in de aynı konunun astronomik izahını yapmaya çalıştığı dikkat çekmektedir. Daha sonra İbnü'l-arabî $(638 / 1242) \mathrm{el}$ Futûhâtu'l-mekkiyye'de kendisi için ileri sürdüğü mi'rac olayında bu seyri sülûk-i rûhânî motifini işlemiştir. Avrupa'da da inikası görülen bu edebî tarz, İtalyan şâir Dante'nin (721/1321) İlahi Komedya'sına örnek olmuştur. Anadolu'da da bu konunun astronomik bir izahının yapılmış olması hem İslâm dünyası hem de Anadolu'nun kültür tarihi için bir yenilik olarak görülmektedir (bak. Bayram 1981: 16-22).

\section{Şâir Sultanlar}

Şiire sempatiyle yaklaşıp şâirleri destekleyen Anadolu Selçuklu sultanları arasında şiir söyleyenler de vardı. Bu sultanlarından II. Rükneddîn Süleymân, Kayseri emiri Kutbeddîn Melikşâh'ın kardeşi olup I. Keyhüsrev'in ilk sultanlık dönemine son vermiş ve 588/1192'de onu Konya'dan çıkartarak tahta kendisi geçmiştir. 600/1203 yılına, yani Rükneddîn'in son saltanat yılına kadar direnen ve o yıl yenilip öldürülen Muhyiddîn Mes'ûd Şâh dışında diğer kardeşleri ona itaat etmiştir (Riyâhî 1995: 64). İşrakiye felsefesini benimseyen Rükneddîn Süleymân, bu düşüncesini herhangi bir dedikoduya sebebiyet vermemek için gizli tutmuştur. Hatta bir gün, kendi fikrinde olan bir filozofla görüşürken yanlarına fakih denilen din âlimlerinden biri gelmiş, musahabe esnasında âlim ile filozof münakaşaya başlamışlar. Cevap vermekte aciz kalan âlim, hiddetlenerek Rükneddîn'in huzurunda filozofu tokatlayıp ağır sözler söyledikten sonra, çıkıp gitmiş. Bu davranış karşısında sultanın sessiz kalmasindan dolayı müteessir olan filozof: "Senin huzurunda bana böyle muamele olunuyor da onu menetmiyorsun" deyince, sultan: "Ben bir şey söylesem ikimizi de tepelerdi, senin fikrinin intişarı da mümkün olmazdı" sözleriyle karşılık vermiştir. İşte bu münazara tarzı Sultan Rükneddîn'in fikir hürriyetine hürmetini, serbest münakaşaya verdiği önemi ve soğukkanlılı̆̆ı ile itidalini göstermektedir (Uzunçarşılı 1948: 292-93). İbn Bîbî, kendisi de şâir olan Rükneddîn'in edebiyat hamiliği ve bilgisi hakkında şunları söyler:

Yine cömertlĭ̆i ve iyiliği yüzünden dünyanın ileri gelen âlimleri, fâzilları, şâirleri ve sanatkârları onun sarayına koşup, sanatlarının inceliklerini onun yüce görüşüne arz ederler ondan çok miktarda bağış 
alırlardı. Elbiseye, paraya ve şöhrete kavuşurlardı. Sultan, her birinin nazım ve nesir nakdini, engin bilgisinin ve parlak zekasinin terazisinde ölçüp tartar, mükemmeli eksikten, doğruyu yanlıştan, sağlamı çürükten, kabayı inceden, iyiyi kötüden ayırt eder, şiirleri aruz ve kâfiye açısından ustalıkla değerlendirirdi (I/79-80).

Şâirlere bu kadar değer veren ve onları himayesine alan sultanın kendisi de Farsça şiir söylemiştir. Onun sadece kardeşi Kayseri Meliki Kutbeddîn Melikşâh ile kavgalı olduğu sırada onun için söylediği bir rubaîsi bugün elimizde olup tercümesi şu şekildedir (İbn Bîbî 1996: I/78):

Ey kutup, felek gibi senden baş çekmem seni bir nokta gibi daireye çekmeyince. Başının kasesinden perçemini çekmezsem, vücudumun derileri omzumdan çıksın.

Anadolu Selçuklu sultanlarından I. Gıyâseddîn Keyhüsrev de bu dönemde Farsça şiir söyleyen şâirlerdendir. II. Kılıç Arslan'ın küçük oğlu olup hayatı ve saltanatı olaylar ve maceralarla geçmiş, biri 588597/1192-1201 diğeri 601-607/1204-1210 tarihleri arasında olmak üzere iki kez sultanlık yapmıştır. Anadili Türkçeden başka Farsça, Rumca ve Latince de bildiği söylenen (Uzunçarşılı 1948: 294) Sultan Keyhüsrev, ataları gibi bilginleri ve şâirleri himaye edip onlara taltif ve ihsanlarda bulunmuştur. Râvendî, 603/1206 tarihinde tamamladığ1 Râhatu's-sudûr ve Âyetü's-sürûr isimli Büyük Selçuklular ile İsfahan Selçukluları'ndan bahseden önemli tarih kitabını ona ithaf etmiş ve mukaddimesinde sultanı öven bir kasideye de yer vermiştir (1999: 27-28). Keyhüsrev gurbete çıktığı sırada Rum ülkesinden Şam diyarına giden Şeyh Mecdüddîn İshak'ı Konya'ya davet etmek için yazdığı manzum mektuptan bazı beyitler, İbn Bîbî tarihinde yer alarak günümüze ulaşmıştır (1996: I/11113).

Sultan şâirlerden olan İzzeddîn Keykâvus, Glyâseddîn Keyhüsrev'in büyük oğlu ve Anadolu Selçukluları'nın büyük sultanlarından biridir. Zamanında kültür faaliyetleri yükselmeğe başlamış, ilim ve sanat mensupları himaye görmüş, cülûsunu kaside ile tebrik eden şâirler ihsanlara boğulmuştur. Nitekim Hüsâmeddîn Sâlâr'in kızı tarafından kendisinin cülûsu hakkında yazılıp Musul'dan gönderilen 72 beyitlik kasidenin (Riyâhî 1369: 50-6) her beytine 1000 kırmızı dinar 
vermesi (İbn Bîbî 1996: I/142-7) onun şiir sevgisine ve şâirleri korumasına örnektir. Ayrıca Kadı Burhâneddîn-i Anevî, Enîsüll-kulûb isimli Farsça manzum eserini ona ithaf etmiştir. İzzeddîn Keykâvus, Ankara kalesi haricinde evvelce Namazgâh denilen ve şimdi yerinde Etnografya müzesi bulunan mahalde güzel bir medrese ile dârü'ş-şifâ ismiyle Sivas'ta bir hastane de yaptırmıştır (Uzunçarşılı 1948: 296).

Şiir ve edebiyatla da uğraşan İzzeddîn Keykâvus, Kayseri'de kardeşi Keykubâd'ın muhasarası sırasında yazmış olduğu güzel bir Farsça rubaîsini, önce kendi tarafında olduğu halde kardeşi tarafına geçen Zahîreddîn İli Pervâne'ye göndermiştir. Ölümünden önce söylediği rivayet edilen Farsça hikmet-âmîz ve güzel bir kıt'ası da Sivas dârü'ş-şifâsındaki bir taşa yazılarak ve İbn Bîbî tarafından da tarihine derç edilerek (1996: I/216-17) bize kadar gelmiştir.? İbn Bîbî, İzzeddin Keykâvus'un üslûbu ve belâgatının son derece başarılı olduğunu, nazım ve nesirde kelime ve deyim kullanışının övgüye değer bir ustalıkta bulunduğunu, nükte ve mana zenginliğinde ise ödül alabilecek seviyeye sahip olduğunu kaydetmiştir (1996: I/149).

Sultan şâirlerden olan I. Alâaddîn Keykubâd, Glyâseddîn Keyhüsrev'in oğlu, İzzeddîn Keykâvus'un kardeşi ve halefi olup, Anadolu Selçuklu sultanlarının en büyüklerindendir. İzzeddîn Keykâvus'un ölümü üzerine, devlet büyüklerinin Alâaddîn Keykubâd'ı tahta çıkarmasıyla, Anadolu Selçuklu devletinde büyük bir gelişme meydana gelmiştir. Siyasî, idarî ve askerî yönlerden parlak bir devrin yaşandığı, iktisadî refahın arttığı ülkede, büyük bir imar faaliyetine girişilmiş, millî birliğin kurulmasına çalışılmıştır. Zamanı, Selçuklu devletinin en kudretli ve mesut devrini teşkil eder. Moğol istilâsı üzerine yakın şarka göç etmek zorunda kalan birçok âlim, mutasavvıf, şâir ve edip Anadolu'ya yerleşerek, burada ilmî ve edebî faaliyetlerin artmasına sebep olmuştur. Ayrıca o tarihe kadar umumî İslâm kültürü çerçevesi içinde mühim bir

${ }^{7}$ İbn Bîbî tarafından zikredilen ve Yazıcıoğlu tarafından Türkçeye nazmen çevrilen bu şiir şu şekildedir (Turan 2002: 320):

Mâ cihân-râ guzâş̧î̀m u şodîm

Renc ber-dil nigâştîm u şodîm

Pes ez-în nevbet şumâst ki mâ

Nevbet-i hîş dâştîm u şodîm
Bu cihânı kim terk edüp gittik

Rencini dilde berk edüp gittik

Şemden sonra nevbet erdi size

Nitekim evvel ermiş idi bize 
konumu olmayan Anadolu, önem kazanmaya başlamıştır. Mevlânâ Celaleddîn-i Rûmî'nin babası Bahâeddîn Veled ile vahdet-i vücûd felsefesinin önderi olan İbn-i Arabî onun zamanında Anadolu'ya gelmiş; Şeyh Sadreddîn-i Konevî, Mevlânâ Celaleddîn-i Rûmî, Necmeddîn-i Dâye, Burhaneddîn Muhakkik-i Tirmizî gibi büyük mutasavviflar da onun döneminde büyük bir saygı ve hürmete mazhar olmuşlardır (Uzunçarşılı 1948: 296).

Keykubâd bilgisi, cesareti, şiir, edebiyat ve sanatı himayesi bakımından kendi hanedanındaki fertler arasında özel bir yere sahiptir. Şâirleri ve sanatkârları himaye etmiş, onlara ilgi ve iltifatta bulunmuştur. Nitekim Necmeddîn-i Râzî, Mirsâdu'l-ibâd isimli eserini kendisine hediye etme maksadıyla yanına gelince, ona aşırı derecede ilgi ve iltifatta bulunmuş; eserinin her harfi karşılığında ödemede bulunarak onu büyük bir servete kavuşturmuştur. Satranç ve tavlayı iyi oynayan, iyi ok ve cirit atan Alâaddîn Keykubâd, mimarlıkta, kuyumculukta, bıçak yapmada, ressamlıkta ve dericilikte de büyük bilgi ve maharete sahipti (İbn Bîbî 1996: I/247).

Türkçeden başka Arapça, Farsça ve Rumca bilen, ayrıca son ikisini konuşan (Turan 2002: 391) Alâaddîn Keykubâd, eski sultanlardan bahseden kitapları okumayı çok severdi. Nitekim İbn Bîbî, Büyük Gazneli sultanı Mahmûd bin Sebüktegin ile Kâbûs-nâme'nin de müellifi olan İran'ın Âl-i Ziyâr hükümdarlarından Kâbûs bin Veşmgîr'e hayranlık duyup onları dilinden düşürmeyen ve kendisine örnek alan Alâaddîn Keykubâd'in sürekli olarak Gazâlî'nin Kîmyâa-yı Sa'âdet'i ile Nizâmü'lmülk'ün Siyerü'l-mülûk (Siyâset-nâme)'unu okuduğunu da kaydetmektedir (1996: I/246). Müzisyenlerin semaını dinlerken musikî kitaplarından, vezin, kafiye, usul gibi konulardan bahseden sultan, bazen zengin tabiatından, berrak ve saf kalbinden süzülen ve şahane incilere benzeyen rubaîler de söylemiştir. İbn Bîbî'nin eserine aldığı (1996: I/246) ancak, Ömer Hayyâm'a ait olarak tanınan bir rubaîsi (Riyâhî 1995: 71) günümüze kadar gelmiş olup tercümesi şu şekildedir:

Ayıkken akıl üzerine dayanırım. Sarhoş olunca akıl benden kaçar. Şarap iç! Çünkü sarhoşluk ve ayıklık arasındaki vakit, hayatın ta kendisidir. 
$\mathrm{Bu}$ sultanlar şiir yazmalarının yanında yazılan şiirleri eleştirip Arapça ve Farsça yazılan eserlerin üslûbu hakkında düşüncelerini ifade etme bilgi ve yeteneğine de sahiptiler. Nitekim İbn Bîbî, Sultan Rükneddîn Süleymânşâh'ın şâirlerin ve nâsirlerin eserlerini engin bilgisinin ve parlak zekasının terazisinde ölçüp tarttığını, mükemmeli eksikten, doğruyu yanlıştan, sağlamı çürükten, kabayı inceden, iyiyi kötüden ayırt ettikten sonra, şiirleri aruz ve kafiye açısından ustalıkla değerlendirdiğini belirtir (1996: I/79-80). İzzeddîn Keykâvus'un edebiyatçıların risaleleri ile şâirlerin kasidelerine yaptığı tenkitler ve eleştirilerin de dikkat çekici mahiyette olduğunu kaydeder (1996: I/149).

\section{Şâir Şehzâdeler}

Anadolu Selçuklu şehzadelerinin de sanata, ilme ve edebiyata önem verip şiir söyledikleri görülmektedir. Bu dönem şehzade şâirlerinden olan Nasîreddîn Berkyaruk'u, babası 584/1188 yılında ülkesini taksim ederken Koyluhisar ve Niksar hâkimi olarak atamıştır. Felsefeye meraklı olan Nasîreddîn Berkyaruk, Sühreverdî'nin görüşlerini aklına uygun tabiatına yakın bulduğu için, kendisine rehber edinip bazı düşüncelerini ona dayandırmış ve o konularda araştırma yaparak ilerleme kaydetmiştir. Ayrıca Sühreverdî́nin kendi adına yazdığı Pertev-nâme'yi okuyup inceleyen Berkyaruk, onda yer alan bütün sembol ve incelikleri öğrenmiştir (İbn Bîbî 1996: I/44). Bundan dolayı Şehâbeddîn-i Sühreverdî, felsefede Berkyaruk'un üstadı sayılmaktadır.

İlme önem verip şâirleri ödüllendiren Nasireddîn Berkyaruk, Hürzâd ile Perî-nejâd hikâyesini son derece güzel, akıc1, sanatlı ve mükemmel bir şekilde Farsça olarak nazmetmiştir. İbn Bîbî tarafından belâgat örneğ $i$ ve sanat mucizesi olarak nitelendirilen bu eserin sadece baş kısmı, İbn Bîbî́nin tarihinde yer alarak günümüze kadar gelmiştir (1996: I/41-44).

II. Kılıç Arslan'ın oğullarından Muhyiddîn Mes'ûd Şâh'ın sanata ve sanatçıya gösterdiği sempatiden dolayı, Ankara meliki iken etrafında bir takım şâirler toplanarak edebî bir muhit teşekkül etmiştir. Süleymaniye Kütüphanesi, Hâlet Efendi Nu. 238'de kayıtlı bir mecmua içerisinde bulunan ve Muhyiddîn Mes'ûd Şâh adına Ebû Hanîfe Abdülkerîm bin Ebûbekr tarafından 588/1192 yılından önce tertip edilen El-İhtiyârât minMecma'i'r-rubâ'iyyât adlı bir mecmuanın bize kadar ulaşan birkaç sayfa- 
sıyla fihristinden, 588/1192'den önce yaşayan bazı şâirlerden haberdar olmaktayız. Bunlardan üçünün neseplerine göre Ankaralı oldukları tahmin edilmektedir. Söylenilen rubaîlerin başında ne hakkında olduklarının belirtilmesi de dikkat çekmektedir. Münteceboğlu Bedî'-i Engüriyeî'nin demirci (âhenger), hacamatçı (reg-zen), Habeş ismi ve Hiristiyan çocuğu (tersâ-beçe) hakkında söylenmiş 4; Muhyevî-i Engüriyeî'nin Melik Muhyiddîn, çamaşırcı çocuk [gâzur-puser] (iki adet), saraç (sarrâc), Muhammed ve Ömer adı hakkında söylenmiş 6 ve Hekîm Mahmûd-1 Engüriyeî'nin nalbant (na'l-bend) hakkında söylenmiş bir rubaîsi vardır. Bunların dışında Anadolu'da yaşayıp şiir söyledikleri tahmin edilen Ali Unsâbâdî, Fahrî, İmâm Alî Hayşem ve Seyyid Eşref isimli şâirlerin de birer rubaîleri kayıtlıdır (Ateş 1945: 107-9).

\section{Şâir Devlet Adamları}

Anadolu Selçuklu devlet adamları arasında da şiir söyleyenler bulunmaktaydı. Ebu'l-feth Rükneddîn Süleymânşâh'ın kâtipliğini yaptıktan sonra, vezir olan Muhammed bin Gâzî-i Malatyavî de bu dönem şâirlerinden ve devlet adamlarındandır. Rükneddîn Süleymânşâh döneminden önce İspehbûd Merzbân b. Rüstem'in Merzbân-nâme'sini Taberî dilinden ağdalı bir dille tercüme ve tahrir etmeye başlayan Malatyavî, Rükneddîn Süleymânşâh'in hizmetine girince, onun da teşvikiyle tercümesini Ravzatu'l-ukûl (Düzen 1978) adı altında 598/1201 yılında tamamlayıp Rükneddîn Süleymânşâh'a takdim etmiş ve sultanın teveccühünü kazanmıştır. Fakat devlet işlerinde başarı gösteremediğinden dolayı bu görevden ayrılmıştır. Ravzatu'l-ukûl'un mukaddimesinden Malatyavî'nin bugün mevcut olmayan Mürşidü'l-küttâb adlı bir kitabı ile divan yazışmaları ve dostlarına yazdığı mektuplardan oluşan bir inşa mecmuasının da olduğu anlaşılmaktadır. Malatyavî, Ravzatu'l-ukûl'dan dokuz yıl sonra Hz. Peygamber (S.A.V.)'in hadislerinden seçtiği kırk hadisi anlatan, ayrıca sahabenin sözlerinden ve diğer hikmetli sözlerden de bahseden Berîdü's-sa'âde'yi I. Keyhüsrev adına kaleme almıştır. Bu eserin mukaddimesinden Malatyavî'nin I. Keyhüsrev'in hocası olduğu da anlaşılmaktadır. Müellifin her ne kadar burada bahsedilen eserleri mensur ise de, bugün elimizde bulunmayan yazışma örnekleri ve dostlarına yazdığı mektuplarda bazı şiirlerinin olduğu tahmin edilmektedir (Riyâhî 1369: 62, 1995: 75-76; Ateş 1945: 104-6). 
I. İzzeddîn Keykâvus ve I. Alâaddîn Keykubâd dönemi kâtiplerinden olan Nizâmeddîn Ahmed-i Erzincanî de bu dönemde Farsça şiir söyleyen devlet adamlarındandır. Bir ara I. Alâaddîn Keykubâd'ın gazabına uğramış, fakat daha sonra onun Celâleddîn Harezmşâh karşısında aldığı zaferleri anlatan bir Fetih-nâme yazınca tekrar gözüne girip dîvân-1 tuğrâ reisliğine getirilmiştir. Bir dönem I. İzzeddîn Keykâvus'un sarayına da giren Erzincanî, önce sultana münşi, sonra emîr-i ârız-1 Rûm olmuştur. İbn Bîbî́nin "Sadrazam (sadr-1 kebîr)", "söz meliki (melikü'lkelâm)" ve "saadet kaynağ1 (umdetü's-saâde)" gibi lakaplarla anıp övdüğü (1996: I/147) Nizâmeddîn Ahmed hakkında söylediği:

“...Efendilerin efendisi, bilgi ve fazilet ülkesinin, ağaçların çiçekleri kadar parlak ve zarif ifadelerin sahibi Firdevsi-yi Tûsî́den -Allâh onu cennetinin en güzel yerine getirsin ve suçlarını bağ̆ışlasınsonra kahramanlık destanında daha üstünü bulunmayan, Deri dilinin inci kutusunu ondan daha iyi düzenleyenin bulunmadı̆̆ 1 Vezir Mahmûd'un oğlu lakabıyla meşhur olan Emîr-i arız Nizâmeddîn Ahmed..." (1996: I/220).

sözlerinden, Erzincanî́nin inşa sanatındaki maharetinin yanında şehname yazdığı da anlaşılmaktadır. Nitekim İbn Bîb̂̂ Muhtasarı'nda geçen "Mesnevî inşasında ikinci Firdevsî̀ydi" ibaresi de bunu göstermektedir (Riyâhî 1995: 76). Erzincanî́nin I. Keykâvus'u öven ve Şemseddîn-i Tabes'in kasidesine nazire olarak söylediği kaside (İbn Bîbî 1996: I/14748), sual - cevap rubaîsi (1996: I/220) ile Erzincan'ın fethini müteakip I. Alâaddîn Keykubâd'ın topraklarını çocukları arasında paylaştırdığında, konuyla ilgili olarak sultanın eğlence meclisinde söylediği bir rubaî (1996: I/368) İbn Bîbî tarihinde kayıtlı olup tercümesi şu şekildedir:

İskender'in geleneğini yerleştirip imparatorluk ayinini kanunlaştırınca bir güneşe (yani doğan çocuğa) şahlık sancağı verdin. Şam (hem karanlık ve hem de Şam Eyyubîleri) için sabah aydınlı̆̆ı açtın.

Mecduddîn Ebîbekr de bu dönem şâirlerindendir. İbn Bîbî, I. İzzeddîn Keykâvus'un 617/1220 Şevvalinde vefatından bahsederken, yeni sultanın seçimi hakkında devlet erkanının danıştı̆̆ 1 kişilerden biri olarak Mecduddîn Ebîbekr'i de anarak:

"Dünya fâzillarının seçkini, deorin âkillerinin önde geleni...Sahib Mecduddîn Ebîbekr; güzel hatta ve hızlı yazıda, uygun deyimler 
kullanmada, sözün açıklığında, belâgatın inceliklerinde, nazmın sağlamlı̆̆ında, nesrin akıcılığında, beyan ilminin ayrıntılarım ve mânâ ilminin gerçeklerini bilmede, sayılması çok uzun sürecek olan fesahatin bütün dallarna hâkim olmada engin bir deniz, parlak bir hilâl, ışık saçan bir güneş, aydınlık bir ay, zamanın önde geleni, devrinin seçkini....yazışma metni usulünde (şîve-i inş̧̂ิ-yı teressül) ve şiir söylemede ünü yerleri ve gökleri tutmuş..."

der ve onun meşhur rubaîlerinden bir örnek verir (1996: I/219-20). İbn Bîbî'nin ondan sâhib adıyla söz etmesi ve Deylemlilerin vezirleriyle k1yaslamasından onun Selçukluların veziri olduğu ve aynı zamanda rubaîlerinin de çok meşhur olduğu anlaşılmaktadır (Riyâhî 1369: 65-66, 1995: 79).

II. Keykâvus'un veziri olan Şemseddîn Muhammed-i Isfahanî, bilgin ve şâirliğinin yanında şâir ve edipleri himaye eden bir kişiydi. Cüveynî-i Sâhib-divân'la karıştırılan Muhammed-i Isfahanî'nin çoluk çocuğu ve akrabası yoktu (Riyâhî 1995: 80). I. İzzeddîn Keykâvus'un mutfak sorumluluğu (eşrâf-1 matbah) görevinde bulunan Isfahanî, sultanın meclisinde söylediği bir rubaî dolayısıyla, has kâtiplik (inşâ-yı hâs) görevine getirilmiş, daha sonra vezirliğe kadar yükselmiştir (İbn Bîbî 1996: I/221). Dönemin önemli âlimlerinden olan ve Âlim-zâde diye tanınan Taceddîn-i Tebrizî ile çeşitli konularda münazara eden Isfahanî, Hoca Veliyüddîn Ali'den hüsn-i hat dersleri almıştır. Hatta tertip ettiği meclislerde civar ülkelerden gelen âlimlerle Farsça ve Arapça eserler üzerine konuşulmakta, çeşitli makamlarda musikî dinlenmekte, bazı ilim dallarında özellikle de tarihî konular ile mizah ve lügaz alanlarında müzakereler yapılmaktaydı (İbn Bîbî 1996: II/106-7). Eflâkî, Isfahanî́nin Kayseri'nin hâkimi olduğu dönemlerde Mevlânâ'nın mürşidi olan Seyyid Burhaneddîn'in mürit ve dostlarından olduğunu kaydetmektedir (Ahmet Eflâkî 1989: I/61).

Muhammed-i Isfahanî, II. Keykâvus'un veziri olduğu zaman, o devir vaizlerinden olan Amasya kadısı Melikü'l-kelâm Celaleddîn-i Verkânî, ona 17 beyitlik bir kaside yazarak mektubuyla birlikte birkaç yük de üzüm gönderdi. Isfahanî ise, vâiz Verkânî'nin gönderdiği birkaç yük üzüm ve kasideye teşekkür olarak edibâne bir mektup ve bir kaside göndermiştir (İbn Bîbî 1996: II/108-16). Selçukluların Moğollara yenil- 
mesinden sonra, zindana düşen Muhammed-i Isfahanî, gördüğü birçok işkenceden sonra öldürülmüştür.

Kaşan'a bağlı Cuşkan'dan olan Celâleddîn-i Verkânî de bu dönemin önemli şâirlerindendir. O dönemin vaizlerinden olan Verkânî, aynı zamanda Amasya'da kadılık görevinde de bulunmaktaydı. Takiyüddîn-i Kâşî́nin tertip ettiği Hülâsatü'l-eş'âr isimli mecmuanın ikinci cildinin birinci rüknünde onun bazı kaside, kıt'a ve rubaîlerine rastlanmaktadır (Riyâhî 1995: 81). Yukarıda belirttiğimiz gibi, Celâleddîn-i Verkânî, Muhammed-i Isfahanî, II. Keykâvus'un veziri olduğu zaman, ona 17 beyitlik bir kaside yazarak mektubuyla birlikte birkaç yük de üzüm göndermiş, o da Verkânî́nin gönderdiği birkaç yük üzüm ve kasideye teşekkür olarak edîbâne bir mektup ve bir kaside yollamıştır (İbn Bîbî 1996: II/10816).

Bu dönem şâirlerinden Emîr Kemâleddîn-i Kâmyâr, Keykubâd hükümetinin ileri gelenlerindendir. Felsefeye meraklı olan emir, Sühreverdî'nin öğrencilerinden olup, onun Arapça söylediği felsefî bir şiirine nazire söylemiştir (İbn Bîbî 1996: II/33). İbn Bîbî, tarihinde onun ilmî makamı ile askerî ve siyasî faaliyetlerinden ayrıntılı olarak bahsetmiştir (I/289-90, 386-88, 421-27, 443-58). Nüzhetü'l-mecâlis'te Farsça iki rubaîsi nakledilmektedir (Riyâhî 1369: 72-3, 1995: 83).

Selçuklu devlet ricalinden ve II. Keykâvus dönemi Rum Pervanesi olan Nizâmeddîn Hurşî̂d de bu devir şâirlerindendir. Aksarayî, yetenekli bir kalem sahibi olan Nizâmeddîn Hurşîd'in güzel ibareleri ve isabetli görüşleri olduğunu belirtir (Riyâhî 1995: 114). 655/1257 tarihinde Rükneddîn'in cülûsundan sonra da pervanelik görevini sürdüren Nizâmeddîn Hurşîd, Aksaray'ın Alâiye Kervansarayı'nda ordunun yenilmesine sebep olan Hoca Noyan'ı kabuğu soyulmuş bir armutla zehirlemekle suçlanarak öldürülmüştür. Ölmeden önce duygulu tabiatından ve ince düşüncesinden doğup durumunu tasvir eden bir beyit İbn Bîbî́nin tarihinde yer alarak bugüne kadar gelmiştir (İbn Bîbî 1996: II/150).

I. İzzeddîn Keykâvus'un saray debirlerinden olan melikü'l-küttâb Şemseddîn Hamza b. Müeyyed-i Tuğraî́nin İbn Bîbî̀nin tarihinde bir rubaîsi yer almaktadır (I/220). 


\section{Melikü'ş-şu'arâ Unvanlı Şâirler}

Melikü'ş-şuarâ Emir Bahâeddîn Ahmed bin Mahmûd Kâni-i Tûsî de, Anadolu'da Farsça şiir söyleyen şâirlerdendir. VI/XII. asrın sonlarında Tûs'ta doğan Tûsî, Moğol istilası sırasında Horasan'dan çıkıp deniz yoluyla Hindistan'a kaçmıştır. Oradan Aden, Mekke ve Bağdat üzerinden Anadolu'ya gelen Tûsî, 618/1221'de Konya'ya giderek I. Alâaddîn Keykubâd'a intisap etmiştir. Onun ölümünden sonrada II. Glyâseddîn Keyhüsrev ve İzzeddîn Keykâvus'a intisap eden Tûsî, tam kırk sene bu üç padişahın hizmetinde bulunmuş, onların medihleriyle meşgul olmuş ve Selçuklu hanedanı hakkında otuz ciltlik muazzam bir Selçuklu Şâhnâmesi nazmetmiştir. Selçuklu Şâhnâmesi'nde eski İran tarihinden, peygamber kıssalarından, İslâm tarihinin çeşitli dönemlerinden uzun uzun bahsedildiği ve nihayet Gazneliler ve Büyük Selçuklular'dan sonra, Anadolu Selçukluları hakkında çok geniş ve etraflı bilgi verdiği sanılmaktadır (Köprülü 1943: 393-95).

Mürsel Öztürk, İbn Bîbî́nin eserinde şâirleri anılmadan nakledilen bir çok şiir olduğunu, bunların başında Kânî-i Tûsî̀nin şiirleri geldiğini belirtir. Yine Tûsî̀nin Selçuk-nâme isimli eserinin, İbn Bîbî'nin en önemli kaynağ1 olduğunu belirttikten sonra, bu konuda Zebîhullâh Safâ'nın şunları söylediğini nakletmiştir (İbn Bîbî 1996: I/7-8):

Bütün araştırmalar Kânînin Selçuknâme'sini kaybolmuş eserler arasında sayarlar. Fakat bu eserin önemli bir kısmının İbn Bîb̂̂ adıyla tanınmış olan Nasıreddîn Hüseyin Muhammed b. Alînin yazdiğı Selçuknâme de denilen el-Evâmirü'l-Alâ'iyye'nin I. Gryâseddin Keyhüsrev ve Alaaddin Keykubad ile ilgili bölümleri, tamamen Kânî̀nin Selçuknâme'sinden alınmıştır.

Tûsî, ayrıca II. İzzeddîn Keykâvus adına 658/1260 tarihinde manzum bir Kelîle ve Dimne (Kâni'-i Tûsî 1358) de yazmıştır. Padişahlarda bulunması gereken hasletler ve faziletler hakkında söylenmiş uzun bir mukaddime ile başlayan eserin tertibi Nasrullah'ın Kelîle ve Dimnésiyle aynîlik göstermektedir (Ateş 1945: 112). Yaklaşık 4500 beyit olan eserin tek nüshası British Museum (nr. 7766)'da bulunmaktadır. Eflâkî'nin ifadelerine göre, Tûsî, Mevlânâ'ya karşı büyük bir hürmet beslemiş, öldüğü zaman ise ona rubaî tarzında bir mersiye söylemiştir (Ahmet Eflâkî 1989: I/16). 
Anadolu Selçukluları dönemi melikü'ş-şuarasından olan Hüsâmeddîn'in varlığından Sa'deddîn Mes'ûd ile karşılıklı mektuplaşmalarından haberdar olmaktayız. Sa'deddîn Mes'ûd, ona yazdığı mektupların ilkinde kendisiyle görüşmek arzusunda olduğunu, bu maksatla "sahil dağlarına muvassalat" ettiğini, müthiş fırtına ve sellerin yolları kapaması üzerine geri döndüğü için hasret ve firakının arttığını edebî bir dille anlatmıştır. Hüsameddîn'in buna cevabı uzun bir kaside ile başlamakta ve kaydedilen bir tarihî hadise ile mektubunun zamanını da belirtmektedir. Gerçekten de aynı arzu ve dostluk hislerini dile getiren şâir, Mu'îniddîn Pervâne'nin Sinop'a hücumundan önce Merzubânnâme'nin şerhi olan, bu kaside ve mektuptan başka birkaç name daha yazdığını, ancak gönderecek kişi bulamadığı için onları da buna ilâve ederek gönderdiğini belirtmektedir. Gerek Hüsameddîn'e ve onun oğlu Emir Nasrullah'a yazılan mektupların gerekse Hüsameddîn'in ona verdiği cevapların tamamıla edebî manzum ve mensur parçalardan ve dostane hisleri ifadeden ibaret olduğu görülmektedir (Turan 1988: 157$58)$.

\section{Tek Kadın Şâir}

Erguvan Hatun, bu dönemde kadın olmasından dolayı dikkati çeken şâirlerdendir. Kocası Cemâleddîn'e yazmış olduğu mektubuna eklediği şiirinde, bir kadın şâirin duyduğu hasret ve iştiyakı dile getirmiştir. Bu mektup Anadolu Selçuklu döneminde bir kadın şâirin varlığını, yüksek zümrenin hususî hayatını ve özellikle karı-koca münasebetlerini göstermesi bakımından oldukça önemlidir. Kocası Cemâleddîn'in Erguvan Hatun'a yazdığı mektuba dört beyitlik bir şiirle başlaması, kendisinin de şâir olduğunu göstermektedir (Turan 1988: 168-71).

\section{İrfanî Şiirin Temsilcileri}

Bu devrin hiç şüphesiz en önemli sufî şâiri Mevlânâ'dır. Yûnus Emre, Sultan Veled ve Evhadüddîn-i Kirmâni de sufî şâirlerdendir (bak. Türk Edebiyatının İlk Temsilcileri). Bu dönemin mutasavvıf şâirlerinden olan Fahreddin-i Irâkî, Hamedan yakınlarındaki Kumcan kasabasında doğmuştur. Ciddi bir tahsilden sonra 627/1299 sıralarında, serseri sûfîlerden oluşan bir Kalenderler zümresine katılarak, Hindistan'a git- 
miş ve burada tanınmış şeyh Bahâeddîn Zekeriyyâ Multânî'nin (ö. 666/1276) müridi ve damadı olmuştur. Bu evliliğinden Kebüriddîn İsmail isminde bir oğlu oldu. Uzun bir müddet Hindistan'da kaldıktan sonra, hacca gitmiş, oradan Anadolu'ya gelerek büyük sûfî Sadreddîn-i Konevî (ö. 672/1273)'nin Fusûs dersine, yani İbn-i Arâbî́nin bu addaki eserini açıklamak için verdiği derslere devam etmiştir. Bu derslerden aldığı ilham ile aşk hakkında en tanınmış eserlerden biri olan Lema'ât'ını (Şeyh Fahruddîn İbrahim-i Hemedânî 1373: 381-416, Fahrüddîn İrâkî 1988) yazmıştır. Anadolu Selçukluları veziri Muînüddîn Pervâne ona Tokat'ta bir tekke yaptırdıysa da galiba Moğol istilasından sonraki Anadolu'nun karışık durumundan dolayı burada kalmayarak Mısır'a gitmiş, oradan geldiği Şam şehrinde 688/ 1289'da vefat ederek Sâlihiye'de tanınmış sûfî Muhyiddîn İbnü'l-Arâbî'nin türbesi yakınına defnedilmiştir (Ateş 1968: 160).

Irâkî'nin Farsça olarak kaleme aldığı manzum ve mensur eserleri bir külliyât halinde toplanarak neşredilmiştir (Şeyh Fahruddîn İbrahim-i Hemedânî 1373). Külliyât'ta kaside (39-86), gazel (87-250), terci-bend (251-78), terkib-bend (279-91), k1t'a (292-295) ve rubaîlerden (359-80) oluşan bir divanı bulunmaktadır. Fahreddîn-i Irâkî̀nin Deh-fasl diye de anılan Uş̧̧âk-nâme (Şeyh Fahruddîn İbrahim-i Hemedânî 1373: 297-357) isminde bir mesnevîsi de vardır. İrâkî, Vezir Şemseddîn-i Cüveynî̀ye ithaf ettiği eserinde, aşkla ilgili düşüncelerini bazen konuyla ilgili hikâyeler anlatarak açıklamıştır.

Anadolu'da yaşayan ve tam adı Seyfeddîn Ebu'l-mahâmid Muhammed-i Ferganî olan Seyf-i Ferganî, şiirlerinden ve Üniversite Kt. FY 171'de kayıtlı olan divanının sonunda bulunan kayıtta yer alan "imam, âlim, zâhid, seyyidü'l-meşâyih ve'l-muhakkıkîn" gibi sıfatlardan anlaşıldığı gibi büyük bir sufî şâirdir. Şiirlerinde Seyf veya Seyf-i Fergânî́ yi mahlas gibi kullanan ve nisbesinden Ferganalı olduğu anlaşılan şâir, Moğol istilâsı üzerine memleketini terk ederek önce Tebrize, oradan da Anadolu'ya gelmiş ve Konya Aksaray'ına yerleşmiştir. Seyf-i Fergânî, "Anadolu'nun göz yaşı" denilebilecek bir şiirinde, Gazan Han (694/1295-703/1304)'a ülkenin durumunu anlatırken başka bir şiirinin başlığında da 705/1305-6 tarihini zikretmiştir. Şâirin bu tarihten sonra çok yaşamadığı tahmin edilmektedir. Seyf-i Fergânî'nin genel olarak 
dinî ve tasavvufî şiirlerini içine alan ve çok yüksek bir seciye ve ruha delâlet eden kaside, kıt'a ve gazel şeklindeki şiirlerinden oluşan bir divanı (Seyf-i Fergânî 1364) vardır (Ateş 1959, 1968: 207-9). Şiirlerinde XIII. asır Anadolu'sunun sosyal ve siyasî yapısını da yansıtan şâir, aynı zamanda içtimaî ve siyasî hicivler de kaleme almıştır (Çiftçi 2002: 269-74).

\section{Diğer Şâirler}

Anadolu Selçukluları döneminde yukarıda zikrettiğimiz şâirlerin dışında başka şâirler de bulunmakta olup şunlardır:

Bu dönemin aynı zamanda önemli münşilerinden olan Râvendî́nin asıl adı Necmeddîn Ebûbekr Muhammed b. Alî b. Süleymân-i Râvendî olup Kâşân vilayetine bağlı Râvend kasabasında doğmuştur. Küçük yaşta babasını kaybeden Râvendî, yoksulluk ve kıtlık nedeniyle 570/1174-1175 yılında ailesiyle beraber, Isfahan'daki dayısı Tâceddîn Ahmed-i Râvendî'nin yanına yerleşmiş ve dayısı tarafından yetiştirilmiştir. Fazıl, bilgin, şâir, yazar ve sanatkâr olan Râvendî, Irak Selçuklularının son padişahı Tuğrul bin Arslan'ın 590/1194 yılında öldürülmesinden sonra Anadolu'ya gelerek Anadolu Selçuklu hükümdarlarından Gıyâseddîn Keyhüsrev ve Kılıç Arslan'in hizmetinde bulundu. 599/1203'te telifine başladığ1 Râhatu's-sudûr ve Âyetü's-sürûr adlı eserini (Râvendî 1333, 1999) 603/1206 yılında tamamlayarak Glyâseddîn Keyhüsrev'e ithaf etti. Bu eser, Fars nesrinin en güzel örneklerinden biridir. Hem sahip olduğu selaset hem de bir çok tarihî ve sosyal olaydan bahsetmesinden dolayı, Moğol saldırısından önce, VII/XIII. asrın en muteber kitaplarından sayılmaktadır. Râvendî, Farsça şiir de söylemiştir. Ancak onun şiirdeki gücü nesirdeki gibi başarılı değildir. Râvendî'nin Glyâseddîn Keyhüsrev'i övmek için yazmış olduğu bir kasidesi, eserinin mukaddimesinde yer almaktadır. Ayrıca eserinde bahsettiği Selçuklu sultanlarıyla ilgili her bölümün sonunda söylemiş olduğu bir şiire de yer vermiştir.

Bu dönem şâirlerinden Kadı Burhaneddîn-i Anevî, Türk asıllı bir kumandanın oğlu olup ilk çocukluk ve gençlik yıllarını Ani'de geçirdi. Farsçanın yanında diğer milletlerin dilleri ile Hristiyan ve Musevîlerin dinî inançları hakkında bilgi edindi. Tefsir, hadis ve fıkıh gibi dinî ilimlerin yanında tıp ve astronomiyle de uğraştı. Ahlatşahlar'dan muhte- 
melen Seyfeddîn Bektemür tarafından Abbasî halifesi Nâsır Li-Dinillah'a elçi olarak Bağdat'a da gönderilen Anevî, Mahmûd isminde bir vaizin telkiniyle Tebriz'de yazmaya başladığı Enîsü'l-kulûb adlı eserini 608/1212 tarihinde Konya'da tamamlayarak sultan I. İzzeddîn Keykâvus'a takdim etti. Kisâ'î ve Taberî gibi tarihçilerin eserlerinden faydalanılarak aruzun feûlün feûlün feûlün feûl kalıbıyla yazılan eser, 28.000 beyit olup ekseriyeti peygamberler kıssasına ayrılmıştır. Bu kıssaların yanında Hz. Peygamber'in miracı, savaşları ve mucizeleri, Hulefâ-yı Râşidîn, Emevîler ve Abbasîler devrinde meydana gelen bazı hadiseler ve halifeler hakkında da bilgi verilmiştir. Aslında dinî-ahlâkî mahiyette bir eser olan ve yedi bölümden meydana gelen Enîsüll-kulûb, Anadolu Selçukluları tarihinin en eski yerli kaynaklarındandır. Bu eserin en dikkate değer yanı, Abbasî halifelerinden söz ettiği kısımda Sünnî geleneğe uyarak X-XII. asır İslâm dünyasının çeşitli vakaları arasında özellikle Gazneli Mahmûd'un Hindistan'daki fetihlerine ve Selçuklulara önem vermesidir. O, Gazneli Mahmûd'un zaferleri arasında sadece Sumenat fethinden bahsetmiş ve ona ait bir menkabe nakletmiştir. Gazneli Mahmûd'u Hindistan'ı fetheden bir İslâm kahramanı olarak telakki eden Anî, onun Türklüğünden hiç bahsetmezken İslâm tarihinde ilk Türk hegemonyası devri olarak Selçuklular dönemini göstermiştir. Müellif, I. İzzeddîn Keykâvus ile Nâsır Li-Dinillah arasındaki münasebetlerden bahsettikten sonra, sultana yaptığı öğütlerin yer aldığı hâtime kısmı ile eserini tamamlamıştır. İhtiva ettiği bazı bilgilerin dışında tarihî kaynak olarak fazla bir değeri olmayan Enîsü'l-kulûb, VI/XII. asırda Anadolu'da yer alan fikrî ve edebî hareketleri, belli bir sınıfın manevî eğilimlerini ve hayat görüşünü yansıtması bakımından özellikle kültür tarihi açısından öneme sahiptir (Davud İbrâhimî 1995: 242-43; Köprülü 1943: 459-70). Bilinen tek nüshası Süleymaniye Ktp. Ayasofya, Nu. 2984'te kayıtlı bulunan Enîsü'l-kulûb'un Kadır Billah'tan Nâsır Li-Dinillah'a kadar gelen Abbasî halifelerine ayrılan ve Gazneliler ile Büyük Selçuklular ve Anadolu Selçukluları dönemine ait bölümleri, özet hâlindeki Türkçe tercümesiyle birlikte Köprülü tarafından yayımlanmıştır (1943: 470-85, 497519).

Bu dönem âlim, şâir ve tabiplerinden olan Sa'deddîn Mes'ûd'un yazmış olduğu tamamıyla hususî mahiyette mektupları ihtiva eden 
önemli bir münşeat mecmuası vardır. Bu mektuplar, kendisi ve Selçuklu ricali hakkında olduğu gibi özellikle devrin edebî, kültürel ve içtimâ̂ tarihi bakımından da önemlidir. Sa'deddîn Mes'ûd'un divan ehlinden olan İmâdeddîn isimli birisine yazmış olduğu iki mektupta Sinop şehrinin güzel bir tavsifi olan ve o dönemin içtimaî ve edebî hayatı bakımından önemli olan şiirlere yer vermiştir (Turan 1988: 156-57, 159-62).

VI./XII. yüzyıl ile VII./XIII. yüzyılın başlarında yaşadığı tahmin edilen Tâceddîn-i Hâletî́nin, Nüzhetü'l-mecâlis'te üç rubaîsi kayıtlıdır (Riyâhî 1369: 72, 1995: 82-3). Şeyh Evhadüddîn-i Kirmânî́nin halifelerinden olan Şeyh Şemseddîn Ömer b. Ahmed-i Tiflisî́nin şeyhi Evhadüddin övgüsünde söylenmiş bazı Farsça rubaîleri vardır (Bayram 1993: 98; Kanar 1999: 16). Yine Şeyh Evhadüddîn-i Kirmânî'nin halifelerinden olan Kerîmüddîn-i Nîşâburî́nin Evhadüddîn'in hem övgüsü hem de ölümü üzerine söylenmiş rubaîleri bulunmaktadır (Bayram 1993: 100; Kanar 1999: 16). Ebu Bekir bin Zekî-i Konevî (Riyâhî 1995: 136-37; Ateş 1945: 120-22), İbn Bîbî (İbn Bîbî 1996), Mühezzeb-i Kayserî (Riyâhî 1995: 93-6), Nâsireddîn Sicistanî-i Sivasî (Riyâhî 1995: 137), Necmeddîn-i Râzî (Miftâh 1374: 65-6), Sadruddîn-i Konevî (Sadeddin Nüzhet vd. 1926: 89-93), Sirâceddîn-i Urmevî (Deyhîm 1367: I/335-7; Riyâhî 1995: 132-35) bu dönemin diğer şâirleridir.

\section{Arapça Şiir}

Anadolu Selçukluları döneminde Arapça şiirler de kaleme alınmıştır. XII. asırda yaşayan ve I. Sultan Kılıç Arslan zamanında Anadolu'ya gelen İran'ın büyük mutasavvıflarından olan Şihâbeddîn-i Sühreverdî'nin tasavvufî mahiyette Arapça şiirleri bulunmaktadır. Ayrıca İbn Sînâ'nın Arapça olarak kaleme aldığı Kasîde-i Rûhiye'sine de bir nazire yazmıştır (Van den Bergh 1997, Sühreverdî 1988: IV-V). İbn Arabî'nin çeşitli mensur eserlerinde bulunan Arapça şiirleri, tasavvufî mahiyette söyledikleriyle birlikte bir divanda toplanmıştır. Ayrıca Divan'ın sonunda muvaşşahat tarzında söylenmiş şiirlere de yer verilmiştir (Ateş 1945: 53-54; 1997: 545). Sultan Veled ve Evhadüddîn-i Kirmanî́nin de Arapça şiirleri bulunmaktadır. 


\section{Türkçe: Edebî ve Resmî Dile Doğru}

Anadolu'ya gelip yerleşen Türklerin çoğunluğunu Oğuz Türkleri oluşturduğu için, Anadolu'da oluşan Türkçenin esasını Oğuz Türkçesi teşkil etmiştir. Anadolu'ya göç eden ve Anodolu Selçuklu Devleti'ni kuran Türklerin, edebî gelenekten yoksun göçebe Oğuz boylarına dayanması sebebiyle; bunların beraberinde getirdikleri dil, bir yazı dilini besleyecek özellikleri taşımamaktaydı. Ayrıca bunlar Kaşgarlı Mahmud'un Hakaniye Türkçesi dediği Orta Asya edebî dilini de bilmiyorlardı. Bundan dolayı, Anadolu'da Türkçeye dayalı bir yazı dilini kurmaya çalışan Türkler, uzun yıllar Arapça ve Farsçanın desteğini almak zorunda kalmışlardır (Korkmaz 1995: 274).

Buna karşılık, Anadolu'nun fethi ve Müslümanlaştırılması için savaşan alp-erenlerin ve gazilerin gösterdikleri gayretlerle Anadolu, daha XII. yüzyılda Türklerin dinî-menkabevi destan edebiyatı geleneklerini sürdürdükleri uygun bir ortam hâline gelir. Bizanslılara karşı savaşmış Müslüman bir Arap kahramanı olduğu ileri sürülen Battal Gazi (Ocak 1992) etrafında meydana getirilen Battal-name (Köksal 2003) Anadolu'nun fethi sırasında Türk gazilerini gayrete getirmek, gönüllerindeki cihat ruhunu artırmak için yazılmıştır. Yine bu devirde, Danişment Ahmet Gazi'nin (Özaydın 1993a) kahramanlıklarının menkabe ile karışık olarak anlatıldı̆̆ Danişmend-name (Akkaya 1954; Mélikoff 1960) de Anadolu'da aynı düşünceyle bu devirde oluşturulmuş bir destandır. Battalname'nin metni daha XIII. yüzyllda tespit edildiği gibi, 643/1245'te II. İzzeddin Keykâvus'un emriyle Münşi-i Sultani Melik İbn Ula'nın Danişmend-name'yi "essah-1 rivayat üzre tasnif" ettiği bilinmekte ise de, bu metin şu an için kayıptır. Daha sonra II. Murad'ın emriyle Tokat dizdarı Arif Ali Danişmend-name' yi manzum ve mensur olarak yeniden kaleme almıştır. Bu durum millî geleneklerine çok bağlı olan Oğuzların yani Türkmenlerin, Orta Asya'da yaratmış oldukları destan geleneğini Anadolu'da da sürdürdüklerini göstermektedir. Fetih sırasında orduda savaşan, savaş sonrasında köy köy, diyar diyar dolaşarak destanlar ve şiirler okuyan, halk hikâyeleri anlatan ozanların yarattığı sözlü edebiyat geleneği ürünlerinin Anadolu'nun ilk devirlerinde halkın bedii ihtiyacını karşıladığı anlaşılmaktadır (Mazıoğlu 1972: 297-98). 
Türk asıllı şâirler, özellikle Türk dilli şâirlerin oluşumu ve gelişiminde etkili olduğu ve bedii zevklerini yansıttıkları İran edebiyatı estetiğinin mahsulü olan klasik şiire Gazneli ve Selçuklu dönemlerinde olduğu gibi Anadolu'da da kendi dilleri yerine Farsça ile vücut vermişlerdir. Bu şiirde Türkçeye geçiş azdan aza küçük denemelerle olmuştur. Mülemmalar ve Farsça mısralar arasındaki Türkçe kelimeler bu geçişin hem ilk basamakları hem de ilk habercisi görünümündedir (Akün 1994: 393). Özelikle bu duruma Anadolu Selçuklu Devleti'nin karışık kültürlerden oluşması ve çok dilli bir ortam sunması da uygun bir zemin hazırlamıştır. Bu da her topluma kendi diliyle hitap eden çeşitli eserlerin yazılmasına sebep olduğu gibi, çok dilli şiirlerin (mülemma) yazılmasına da zemin hazırlamıştır. Çünkü bu tip toplumlarda her dilin kendine has farklı işlevleri vardır ve her biri belirli bir amaç ve durum için kullanılır. İşte çok dilli şiirler de bu durumun işlevsel bir yansımasını sergilerler (Johanson 1993: 29). Hatta bu tip davranışın özellikle zengin bir Halk edebiyatı geleneğine sahip olan Oğuz Türkçesinin aruz vezniyle söylenilen edebî metinlerde de kullanılmasıyla edebî olarak etkin bir hâle gelmesine yardımcı olduğu görülmektedir. Yani bu mülemma şiirler edebî açıdan fazla işlenmemiş olan Oğuz Türkçesinin işlenmiş olan dillerin özellikle de Farsça ve Arapçanın çatısı altında talim imkânı elde ettiği söylenebilir. Nitekim Köprülü'nün değerlendirmesiyle Horasan ve Maveraünnehir şâirlerinin oldukça etkin bir dönemde aruzla şiir yazmaya Türkçe-Farsça mülemmalarla başladıkları (Johanson 1993: 34-35) gibi Anadolu'da da aynı durumla karşılaşmaktayız. Tabii ki burada Johanson'un ifade ettiği gibi, bu dönemde modern tarzda dil ve millet bütünleştirilmediği için son dönemlerdeki millî dile sadakat veya dil milliyetçiliğinin olmadığı da hatırlanmalıdır. Ayrıca Orta Çă̆ Avrupa edebiyatında olduğu gibi dil tercihi sanatçıların milliyetine göre değil, edebî türe göre belirlenmekteydi (1993: 28).

Anadolu'da Türkçeye geçişin önemli sebeplerinden biri de İhsan Fazlıŏlu'nun ilk defa dikkat çektiği gibi muhatap olarak alınan halkın kendisine takdim edilen dili anlamasıdır (bak. 2003). Anadolu'da da yoğun bir Türk halkı bulunduğundan dolayı, doğal olarak o insanlara kendi diliyle hitap etme ihtiyacı doğmuştur. Ayrıca Anadolu'da Türk diliyle yazılı bir edebiyata varışta gözden kaçırılmaması gereken hususlardan biri de, hiç şüphesiz bölgede gittikçe kuvvet kazanmaya başlayan 
tasavvuf cereyanıdır. XIII. asrın ilk çeyreğinin sonlarına doğru Moğol istilasından kaçıp Anadolu'ya gelen birçok büyük sufînin tesiriyle I. Alâaddîn Keykubâd devrinden başlayarak tasavvufî düşünce hız kazanmıştır. Diğer taraftan yine aynı sebeplerle bu defa Orta Asya ve özellikle Horasan sahasından Türkmen şeyh ve dervişleri de bu çağda akın akın Anadolu'ya gelmişleridir. Büyük merkezlerde Farsça bilen şehir halkına aynı dille hitap eden eserler yanında, tasavvuf fikriyatını geniş halk tabakalarına yaymak şevki ve arzusuyla yazılan dinî ve tasavvufî eserlerde Oğuz Türkçesi edebiyat ve yazı dili hüviyetiyle kendini göstermeye başlamıştır. Böylece XIII. asrın ilk yarısı içinde, doğrudan doğruya Farsça bilmeyen bir kitleyi irşad gayesi güden Türkçe dinî-tasavvufî bir edebiyatın doğuşuna şahit olunmaktadır (Akün 1994: 393). Bu dinî-tasavvuf edebiyatının bugün için bilinen ilk temsilcileri Sultan Veled ve Yunus Emre'dir. Yine Selçuklular döneminde yetişmiş olan Hoca Dehhânî ise, Anadolu'da din dişı şiirin bilinen ilk temsilcisi olarak kabul edilmektedir.

XIII. asırda, I. Alâaddîn Keykubâd (616/1219-634/1236) zamanında yaşayan Dehhânî́nin şiirleri (İlaydın 1974), nazım tekniğinde ve üslubunda görülen kusurlarına karşılık, dönemine göre gelişmiş bir dile sahip olması, Anadolu'da Türkçe şiirin geçmişinin XIII. asırdan daha gerilere gittiğini düşündürmektedir. Ancak elimizde yazılı veriler bulunmadığı için kesin bir yargıya varmak güçtür. Aynı durum Orta Asya'da da mevcuttur. XI. asra kadar yüksek bir edebiyat ve kültür dili meydana getiren ve aynı asırda Kutadgu Bilig gibi büyük bir eser ortaya koyan Türklerin, edebî alanda birdenbire gerilemesi beklenemez. Ayrıca İslâm medeniyeti dairesine girilmiş olan bu dönemde, en azından İslâm dinini öğretmek için birçok eserin yazılmış olması gerekir. Bu karanlık devrin sebebi Canpolat'a göre Moğol istilasıdır. XII. asrın sonları ile XIII. asrın başlarında yazıldığı tahmin edilen ve bugüne kadar gelmiş olan pek az eserin istinsah tarihlerinin XIV. yüzyıla ve daha sonrasına ait olması da bunu açık bir şekilde göstermektedir (1989: 165-66).

Bugün için aşağıda zikredilen ve Türk dilinin ilk temsilcileri olan şâirlere ait elimizde bulunan metinlerden başka Eski Anadolu Türkçesi özelliklerini taşımakla beraber dil bakımından karışık bir durum gösteren eserler de mevcuttur. Bu durumun en önemli sebebi, özellikle XII. 
asrın sonu ile XIII. asrın başlarında Türkistan'dan Anadolu'ya siyasi ve iktisadi baskılar ile ticari amaçlarla akın akın gelen din adamları, sufiler ve şeyhlerin Anadolu halkı için Oğuz Türkçesi ile kaleme aldıkları eserlerine, kendi anadilleri olan Orta Asya Türkçesinin hususiyetlerini bilerek veya bilmeyerek katmalarıdır (Kut 2004: 320). Bunlardan birisi, Ali adlı bir şâirin 630/1232'de, 8'li hece vezni ve dörtlüklerle yazmış olduğu Yusuf u Züleyha (Ertaylan 1960; Hace Alî-i Harezmî 1376) hikâyesi; diğgeri ise $703 / 1303$ 'te Şeyh Ali b. Muhammed tarafından istinsah edilen ve dilinden XIII. asırda yazıldığı tahmin edilen Behcetü'l-Hada'ik fiMev'izeti'l-Hala'ik (Ertaylan 1949; Buluç 1955, 1956, 1988; Canpolat 1989) adlı dinî-ahlaki eserdir. Dil bakımından karışık bir durum arz eden bu eserlerin nerede yazıldıkları bilinmemekle beraber, Selçuklular devri Oğuz Türkçesiyle kaleme alındıkları söylenmektedir. Bu eserlerin dilindeki karışıklığın sebebi, Anadolu'ya Oğuz boyları ile birlikte sayıları az da olsa Orta Asya'dan başka Türk boylarının da gelmeleri ve Oğuz Türklerinin yazı dili olarak göçlerle bağlarını devam ettirdikleri Doğu Türkçesini kullanmış olmaları gösterilmektedir (Mazıoğlu 1972: 301). XIV. asırda yaşayan Şeyyad Hamza (Mansuroğlu 1946) ve Kadı Burhaneddin'in de Doğu Türkçesiyle karışık şiir yazmaları bu durumu doğrulamaktadır.

Anadolu Selçukluları devrinde Anadolu'da yazıldığı halde bugün elimizde bulunmayan Türkçe eserler de vardır. Bunlar, Gülşehrî̀nin Mantıku't-Tayr'ında "Bir kişi bu dâsitânı eylemiş / İlle lafzın key çepürdük söylemiş // Eski bizden hûriye ton eylemiş / Bir keçeden aya pîlven eylemiş // Veznçün lafzuñ gidermiş harfini / Artuk eksik söylemişsöz sarfinı" (1957: 51) misralarıyla haber verdiği ve acemice yazıldığını söylediği manzum Şeyh San'an Kıssası ile Şeyyad İsa'nın Salsal-name isimli eseridir. Fuad Köprülü'nün XIII. asırda yazıldığını söylediği Salsal-name, bir kahramanlık hikâyesi olup, Salsal adlı bir devin Hz. Ali ile savaşını ve yenilip yok olmasını anlatır. Bu hikâye, sonraki yüzyıllarda da çeşitli şâirler tarafından yazılmıştır (1986: 253).

Bu dönemde, Karamanoğlu Mehmet Beğ, Anadolu Selçuklularının son zamanlarına doğru, memleketteki karışık durumdan faydalanarak Konya'yı Alâaddîn Keykubâd'dan alıp devlet idaresini vezir sıfatıyla ele aldıktan sonra, 15 Mayıs 1277'de (H. 10 Zilhicce 675) "Bugünden sonra hiç 
kimse divanda, dergâhta, bargâhta, mecliste ve meydanda Türkçeden başka dil konuşmayacak" (İbn Bibi 1996: II/209) şeklindeki kararını bütün şehre ilan ettirip "defterleri dahı Türkçe yazalar" (Korkmaz 1995: 428) buyruğunu verir. Bu buyruktan sonra Anadolu'da VI. yüzyıldan XIII. yüzyıla kadar ayrı ayrı bölgelerde tek bir kol hâlinde ilerleyen eski Türk yazı dilinden ayrılıp yepyeni karakterde müstakil bir yazı dilinin kuruluşu sağlanmış (Korkmaz 1995: 424), Türkçe ilim ve edebiyat dili olarak Arapça ve Farsça karşısında geçerlik kazanmaya başlamış ve resmi dil olmuştur. Böylece takriben XI. asırdan itibaren Şuubiye hareketi dolayısıyla hakimiyetini kısmen Farsça ile paylaşan Arapça; XIII. özellikle de XIV. yüzyıllarda başlamak üzere Türkçe ile paylaşmak zorunda kalmıştır (Sayılı 1964: 47). Türkler, Anadolu'da Türkçenin sadece konuşma dili olarak kalmayıp bir kültür ve medeniyet dili olmasının temellerini de yine bu dönemde atmışlardır.

\section{Anadolu'da Yazılan İlk Türkçe Şiir}

Bugünkü bilgilere göre Anadolu'da yazılan ilk Türkçe şiir, Evhadüddîn-i Kirmânî tarafından kaleme alınmıştır (bak. Türk Edebiyatının İlk Temsilcileri).

\section{Anadolu'da Yazılan İlk Türkçe Eser}

Anadolu'da yazılan ilk Türkçe eser meselesi üzerinde ilk defa Fuad Köprülü durmuştur. Köprülü, Ahmed Fakîh'in Çerh-nâme isimli kasidesini, Anadolu'da yazılan ilk Türkçe eser olarak kabul etmiştir (Köprülüzâde Mehmed Fuad 1926a). Ancak son yapılan araştırmalar bu eserin 1350'den sonra kaleme alındığını göstermektedir (Tezcan 1994; Şentürk vd. 2007: 148-50). Bu sebeple, eldeki bilgilere göre Anadolu'da yazılan ilk Türkçe eser, Hekim Bereket tarafından kaleme alınmış, tıp ilmine dair Tuhfe-i Mübârizî olmalıdır (Bayram 2004: 10-11). Bu eseri, Şehabeddin Tekindağ geniş olarak tanıtmış (1971: 134-39)'tır. Hekim Bereket eserinin mukaddimesinde bildirdiğine göre, bu eseri Lubâbü'nNuhab adıyla Arapça olarak yazmış, daha sonra bunu Tuhfe-i Mubârizî adıyla Farsçaya tercüme edip Amasya emiri Halifet Alp Gazi'ye sunmuştur. Hekim Bereket, onun tıp ilmi için faydalı olacak bu eseri beğendiğini, ancak Türkçe olarak kaleme alınsaydı değerinin daha da artaca- 
ğını ifade ettiğini, bundan dolayı da bir süre sonra Türkçeye çevirdiğini belirtir (Tekindağ 1971: 134-36). Yine Hekim Bereket'in bu ifadelerinden bu dönemde Türkçe eserlerin çok nadir olarak mevcut olduğu, Halifet Alp Gazi'nin de Türkçe eserler yazılmasını teşvik ettiği anlaşılmaktadır. Büyük ihtimalle, bu teşvik neticesinde Hekim Bereket Hulâsa der-İlm-i $T \imath b$ adıyla yine Türkçe bir başka eser yazarak yine Emir Halifet Gazi'ye takdim etmiştir. Yine aynı cilt içersinde müellifi bilinmeyen Tabiat-name isimli Türkçe bir mesnevî bulunmaktadır. Bu mesnevînin Hekim Bereket'in diğer iki eseri gibi tıbba dair ve bir cilt içinde bulunması, dilinin ise çok eski olmasından dolayı Hekim Bereket'e ait olduğu sanılmaktadir (Bayram 2004: 110).

Mahmud Mes'ud Koman, Tuhfe-i Mübârizînin hattıyla, eserin kapağında kayıtlı notun hattının farklı oluşuna dikkat çekerek, Tuhfe-i Mübârizı̃nin mukaddimesinin ve dil hususiyetlerinin Aydınoğlu Mehmet Bey adına tercüme edilen Kısas-ı Enbiyâ ve Tezkiretü'l-Evliyâ'daki mukaddimelere ve dil hususiyetlerine benzediğini ifade ederek: "...namina kitap ithaf olunan bu büyük ve nüfuzlu emirin Aydınoğlu Mübarizü'd-dîn Mehmed Bey olduğunu kuvvetle tahmin ediyoruz" demektedir (1955: 701; Derin 1987: 5-6). Bu eserin ithaf edildiği şahıs, 1225 (Tekindağ 1971: 138) veya 1232 (Bayram 2004: 111) yılında şehit edilen Amasya Emiri Halîfet Alp Gazi ise, eserin XIII. asrın ilk yarısında; eğer bu şahıs 1330 yılında ölen (Koman 1955: 703) Aydınoğlu Mehmet Bey ise, eserin XIV. asrın ilk yarısında tercüme edildiği söylenebilir. Ancak, Hekim Bereket'i Türkçe eserler yazmaya teşvik eden Emir Mübârüziddin Halifet Gazi, tanınan ve bilinen bir kişi olup Sultan I. İzzeddin Keykâvus'un 610/1214 yılındaki Sinop fethine katılmış, Kuzey sahilleri komutanı olmuş, I. Alaaddin Keykubad zamanında Amasya valiliği yapmış, bu sultanın Gürcistan'a sevk ettiği orduda da bulunmuş ve bu seferde iken 629/1232 tarihinde şehit düşmüştür. Halifet Gazi 606/1209'da Amasya'da bir medrese yaptırmıştır. Hekim Bereket'in 622/1225 tarihli bir vakfiyesi (Yınanç 1982) bulunan bu medresede müderrislik yaptığı tahmin edilmektedir. Ayrıca Koman'ın dikkat çektiği ve Tuhfe-i Mübarizînin kapak kısmında yer alan kayıttan Halifet Gazi'nin babasının adının Tolı, dedesinin ise Terken Şah olduğu anlaşılmaktadır (Bayram 2004: 110-11). Bunların her ikisinin de adı Danişmend-name'nin kahramanları arasında geçmektedir (Turan 2002: 131). Bu da Halifet 
Gazi'nin, Amasya emiri Melikü'l-ümerâ Mubârizu'd-devle ve'd-dîn Halifet Alp Gazi olduğu ihtimalini artırmaktadır. Ayrıca Türkmencilik hareketi ile Türk kültürünün himaye edilip desteklendiği yer olan Amasya'da, Türkçe eser yazma geleneğinin de başlamış olabileceğini göz önünde bulundurmak da gerekir.

Görülüyor ki, eldeki yazılı metinlere göre Anadolu'da Türkçe eser verme geleneği XIII. asrın başlarında başlamıştır. Mustafa Canpolat'ın, Behcetü'l-Hada'ik'in Anadolu'da muhtemelen XII. asrın sonları ya da XIII. asrın başlarında yazılmış olması gerçeğe en yakın ihtimaldir görüşü de (1989: 165-75) bunu desteklemektedir. Bu da, bazı kaynaklarda ifade edilen (İz 1995: II/XXVIII), Anadolu'daki ilk Türkçe eserlerin XIII. asrın ortalarına doğru verilmeye başlandığı görüşünün doğru olmadığını göstermektedir.

\section{Türk Edebiyatının İlk Temsilcileri}

Anadolu'daki Türk edebiyatının, Anadolu Selçuklularının son dönemlerinde (XIII. Yüzyıl) yaşayan ilk temsilcileri, bazı Türkçe şiirleri/eserleri olduğu bilinen Evhadüddîn-i Kirmânî, Yûnus Emre, Dehhânî, Mevlânâ Celâleddîn-i Rûmî, Sultan Veled ve Nâsırî'dir. Aynı döneme ait gösterilen Şeyyâd Hamza ve Ahmed Fakîh'in, son yapılan araştırmalar neticesinde XIV. asırda yaşadığ1 tespit edilmiştir. Bugün hâlâ Yûnus Emre ve Dehhânî́nin de yaşadığg dönemle ilgili farklı iddialar ileri sürülmektedir.

\section{Evhadüddîn-i Kirmânî}

Anadolu'da en eski Türkçe şiir söyleyen şâir olan Evhadüddîn-i Kirmânî́nin İran'ın Kirman bölgesinde 559/1164'te doğduğu tahmin edilmektedir. Türk olduğu sanılan Evhadüddîn'in asıl adı Hâmid, lakabı Evhadüddîn'dir. Şiirlerinde 'Evhad' mahlasını kullanmıştır. Tahsilini Bağdat'ta tamamladıktan sonra, önce 'muîd (asistan)' daha sonra 'müderris (profesör)' olarak Hankâhiye medresesinde çalışmaya başlamıştır. Ancak tasavvufa meyleden Kirmânî, medrese ile hankahlar arasındaki eğitim farkını görmüş ve Kutbuddîn-i Ebherî́nin halifesi Rukneddîn-i Sucasî̀ye (608/1211) intisap ederek tasavvuf yoluna girmiştir. Seyyah bir sufi olarak tanınan ve Evhadiyye tarikatının kurucusu olan Kirmânî, 
İran, Azarbaycan Kafkasya, Anadolu, Irak, Suriye, Misır ve Hicaz'in birçok köy ve kasabalarında bulunmuştur. Gittiği her yerde devlet adamı ve sultanlardan hürmet gören Kirmânî, muhtemelen 1204 yılında Anadolu'ya gelmiş ve ertesi yıl Konya'da bulunan Muhyiddin ibnü'1Arabî ile görüşmüştür. Bu arada Malatya, Sivas ve Konya'ya gittiyse de genellikle Kayseri'de ikamet etmiştir. Fütüvvet teşkilatının Anadolu'daki şeyhlerinin lideri olarak halife tarafından gönderilen ve uzun bir süre "Şeyhu'ş-şuyûhi'r-Rûm" unvanını taşıyan Kirmânî, Kayseri'de evlenmiş ve Fatıma isminde bir kızı olmuştur. Mikâil Bayram'ın tespitlerine göre, Fatıma adındaki bu kız, Bâcıyân-ı Rûm adındaki kadınlara özgü olan sivil örgütün lideri Fatıma Hatun'dur. Kirmânî, Riyâzu'l-ârifîn'e göre Bağdat'ta 635/1238 tarihinde vefat etmiştir (bak. Bayram 1996; Kanar 1999).

Mehmet Kanar, Evhadüddîn-i Kirmânî'nin 2202 tane rubaîsini tespit etmiştir (bak. Kanar 1999). Bunlardan 1153'ü Farsça, 16'sı Arapça, 33'ü ise Arapça-Farsça mülemmadır. Bu rubaîlerdeki konuların işlenişine, mazmunlara, kelime seçimlerine ve edebî sanatların kullanımlarına bakıldığında, Kirmanî'nin ilmî yönü ağır basan, akılcı Hayâm ile Fahrüddîn-i Irâkî, Senâ'î ve Mevlânâ gibi ilâhî coşku ve heyecan dolu şâirler arasında bocalayan, vazgeçemediği şahidbazlık dolayısıyla her taraftan gelen baskılara karşı koymaya çalışan, istisnai rubaîler dışında zaman zaman zevksiz ve sıkıcı sanat gösterisi yapmaya çalışan, taklitten kurtulamamış ve şiire kendi damgasını vuramayan bir şâir olduğu görülmektedir. Rubaîlerde vahdet-i vücûd, şahidbazlık, kadın, ilahî aşk, şeriat, sema, tarikat adabı, kader, ibadet, dünya ve ahiret hayatı, ictimaî durum ve ilim gibi konular işlenmiştir (Kanar 1999: 21-29). Süleymaniye Kütüphanesi'nde (Ayasofya, nr. 2910) bulunan bir mecmuanın baş tarafında Evhadüddin'in bazı nasihatleri, bir mev'izası, biri Halife Müstansır-Billah'a olmak üzere birkaç mektubu bulunmaktadır (Bayram 2005: 90).

Bugünkü bilgilerimize göre, Anadolu'da yazıldığı tespit edilen ve elimizde bulunan Türkçe en eski şiir, XIII. asrın sonlarında Gelibolulu Muhyiddîn tarafından Farsçadan tercüme edilen Tercüme-i Menâkıb-ı Şeyh Evhadüddin-i Kirmanî (Mercan 1989) adlı eserde yer alan ve Kirmanî'ye ait olan Farsça-Türkçe mülemma gazeldir. Bugün "olısar" 
redifli olan bu mülemma gazelin sadece ilk beyti tespit edilmiş olup Türkçe menkabede şu şekilde geçmektedir:

Me-râ ezeddür mescid der-i hammâr olısar ${ }^{8}$

Seccâde neyem lâyık me-râ zünnâr olısar"

(terc. Meyhane olduğu zaman mescit bana zittır. Zünnâr olduğunda ise seccade bana gerekmez.)

Yine aynı eserde yer alan, "Hazret-i Şeyh gûyendelere işâret eyledi, hûb âvâzile Hazret-i Şeyhün bu gazeline ser-âgâz eylediler" ifadelerinden, bu gazelin Şeyh Evhaduddîn'in müritleri tarafından hep bir ağızdan terennüm edildiği de anlaşılmaktadır (Bayram 2005: 209).

Muhammed-i Kazvînî'nin Mecâlisü'n-nefâ'is Tercümesi'ndeki kaydından (Alî Şîr Nevâî 1323: 318; Kartal 2000: 34), Kirmânî'nin şiirlerinin XVI. asırda bile Anadolu'da meşhur olduğu anlaşılmaktadır.

\section{Mevlânâ Celâleddîn-i Rûmî}

Bu dönemde Anadolu'da dinî ve tasavvufî mahiyette eserler kaleme alan müelliflerin başında hiç şüphesiz Mevlânâ Celâleddîn-i Rûmî gelmektedir. Asıl adı tezkire yazarlarının ittifakı ile Muhammed, lakabı Celâleddîn olan, bugün Afganistan'ın kuzeyinde bulunan Belh şehrinde 604/1207 tarihinde doğan Mevlâna, uzun bir seyahatten sonra, Konya'ya gelip yerleşmiş ve uzun müddet burada oturduktan sonra, aynı şehirde 672/1273'te ölmüştür (Mevlânâ'nın hayatı hakkında geniş bilgi için bak. Gölpınarlı 1985a; Furûzanfer 1990; Can 2003). Necmeddîni Kübrâ'nın tarikatına dolayısıyla Horasan tasavvuf mektebine mensup olan babası Sultânu'l-ulemâ Bahâeddîn Veled ile, daha çocuk yaştayken Moğol istilası önünden kaçıp Anadolu'ya gelen Mevlânâ, Şam ve Halep gibi dönemin önemli kültür merkezlerinde sağlam bir tahsil görmüş, şer'î ilimlerde, özellikle fıkıh alanında ihtisas sahibi olmuş, bir taraftan babasından tasavvuf terbiyesi alırken, diğer yandan da ilmî seviyesini yükseltmiştir. Onun bu yetişme tarzının, kendi tasavvuf anlayışını

\footnotetext{
${ }^{8} \mathrm{Bu}$ beyit İsmail Hakkı Mercan tarafından hazırlanan yüksek lisans tezinde yanlış ve Farsça olarak şu şekilde okunmuştur (Mercan 1990: 133): Me-râ ezar der mescid der semâ evlîter / Seccâde nîm lâyık me-râ ez nâr evlîter.
} 
oluştururken hiç şüphesiz büyük tesiri olmuş, Sünnî İslâm anlayışına genelde sağlam bir tarzda sadık kalan bir tasavvufî sistem geliştirmiştir (Ocak 2006b: 433).

Kendinden önceki pek çok meşreptaşı gibi mistik cezbesini, ilahî aşkını ve tasavvufî düşüncelerini terennüm için şiiri bir araç olarak kullanan (Ocak 2007: 17) Mevlânâ, yazmış olduğu eserlerle hem Osmanlı hem de doğu zihniyet dünyasına ve edebiyatına tesir eden önemli bir sufîdir. O'nun tasavvufî anlayışını ve düşüncelerini ortaya koyan Mesnevî̀-i Me'nevî, Dîvân-ı Kebîr, Fîhi Mâ Fîh, Rubâiyyât gibi eserleri, Farsça yazılmış olmalarına rağmen, sanıldığının aksine, o devirde sadece yüksek tabakalara mahsus kalmamış, Türkmen çevrelerine de geniş ölçüde nüfuz etmiştir. Nitekim Mevlânâ'nın o dönemin bir başka ünlü sufîsi Hacı Bektaş-1 Velî ile yakın ilişki içinde olduğu bilinmektedir. Hatta Anadolu'da Türkçenin müdafiliğini yapan XIV. asrın ünlü Türkmen mutasavvıfı Âşık Paşa, Garîb-nâme adlı eserinde Mevlânâ'dan çok istifade etmiş ve onu takdirle anmıştır. Mevlânâ'dan açıç̧a etkilendiğini söyleyen ve ondan büyük bir hayranlıkla söz eden diğer bir Türkmen şeyhi de Yûnus Emre'dir (Ocak 2006b: 433).

Mevlânâ'nın eserlerinden Mesnevî yahut tam adıla Mesnevî-i Ma'nevî (Mevlânâ Calâleddîn-i Rumî 1993; Mevlânâ 1370, 1925-, 1988; Gölpınarlı 1981-), Mevlâna'nın en çok okunan ve hayranlık uyandıran 6 ciltlik eseri olup, 25.634 beyitten oluşmaktadır. Mesnevî nazım şekliyle yazıldığı için bu adı almıştır. Bugün de mesnevî denildiği zaman akla hemen bu eser gelmektedir. Mevlânâ, tasavvufî sırları ve tarikat adap ve erkanını açıklayan bir eser yazmayı düşünmüş ve ilk 18 beytini yazmıştır. Daha sonra Hüsameddin Çelebi'nin, kendisinden Senâ'î'nin Hadîka's1 ya da Attâr'ın Mantıku't-tayr'1 vezninde, irfan sırlarını, tarikat usullerini açıklayan bir eser nazmetmesini teşvik ve arzu etmesi üzerine de Mesnevî̀-i Ma'nevî́ yi yazmaya başlamıştır. Yazmış olduğu bu 18 beyitten sonraki kısımlar Mevlânâ'nın her yerde, her vesile ile Hüsameddin Çelebi'ye yazdırması suretiyle vücuda gelmiştir. Birinci cilt 657-660/12591263 yılları arasında tamamlanmış, uzunca bir aradan sonra 662/1264 tarihinde ikinci cilt yazılmaya başlanmış ve hiç ara verilmeden bütün eser Mevlânâ'nın ölümüne (672/1273 tarihine) yakın bir zamanda tamamlanmıştır (Ateş 1968: 113-14; Furûzanfer 1990: 145-48, 211-12). 
Bu hacimli eser, akıcı bir üslûba sahip olmasına karşılık, dil nazım tekniği bakımından güçlü değildir. Bundan dolayı da sonraki müstensihler bazı üslûp, özellikle de vezin aksaklıklarını düzeltmişlerdir (Ritter 1997: 57). Hiç şüphesiz bunda doğrudan doğruya bir edebî kaygiyla kaleme alınmaması etkili olmuştur. Çünkü kendinisini toplumu aydınlatmakla görevli sayan bir öğretmen gibi gören Mevlânâ'nın asıl derdi, şiir söylemek değil, bilakis mesajını topluma ulaştırmaktır. Bundan dolayı da şiirin kurallarını zorlamaktan hiç çekinmemiştir (Kırlangıç 2007: 222). Mevlânâ didaktik bir eser olan Mesnevî́de, belirli bir plana göre hareket etmemiştir. Herhangi bir münasebetle bir hikâyeyi anlatırken, çok kuvvetli olan tedai kabiliyetiyle başka bir hikâyeyi hatırlamış; o hikâye, kendisini dinî, insanî konulara sürüklemiş, derken bir başka hikâyeyi, bir başka olayı hatırlayıp onu anlatmaya başlamıştır. Bu şekilde devam ederken tekrar ilk hikâyeye dönüp onu bitirmiştir (Gölpınarlı 1981-: I/IX). Belki bundan dolayı Mesnevî, "hikâye içinde hikâye" olarak nitelendirilmiştir (Kırlangıç 2007: 221). Onun bu üslûbu, aynı zamanda eseri okuyanları meraklandırıcı ve sürükleyici bir etki de oluşturmuştur.

İçerisinde birçok tasavvufî, dinî ve ahlâkî terim ve kavramlara yer verilip anlamlarının açıklandığı Mesnevî̃ de anlatılan hikâyelerin bir çoğunun, o devir Anadolu'sunun sosyal, siyasî ve kültürel hadiseleriyle ilgili olduğu da görülmektedir. Mevlânâ, bu hikâyeleri çok ustaca seçmiş ve görüşlerini, hem şâirlik dehasıyla anlatmış hem de muhaliflerini hicvetmekten çekinmemiştir (Bayram 2001b: 21-40).

Özellikle Mesnevî, Türk illerinde en çok saygı gören, en fazla okunan ve en geniş ölçüde şerh edilen, seçmeler yapılan, anlaşılması güç beyitleri için yorumlar düzenlenen, yorumları kuvvetlendirmek için kendisinden hikâye, temsil ve beyitler aktarılan, hatta okuyucular tarafından daha iyi ve kolay anlaşılabilmesi için çeşitli sözlükler hazırlanan bir eserdir. Nitekim bütün bu konularda birçok eserin kaleme alındığ 1 görülmektedir (bak. Çelebioğlu 1978; Öztekin 1998; Kartal 1999: 181-243; Kunt 1996). Ayrıca muhteva olarak içerisinde barındırdığı fikirlerden dolayı da, Türk edebiyatının oluşmasında önemli bir yere sahip olmuştur.

Dîvân-ı Kebîr (Mevlânâ 1345, Mevlânâ Celâleddin 1992), onun gazel ve bir kaç da değişik şekildeki şiir ve rubaîlerini ihtiva eden bir diğer 
büyük eseridir. Ancak rubaîleri ekseriyetle ayrı bir eser hâlinde toplanmiştır (Mevlânâ Celâleddîn-i Rumî 1312, Gölpınarlı 1964, Gençosman 1988, Can 1990, 1991). Mevlânâ, gazellerinin çoğunun sonunda kendi adını veya mahlasını söyleyeceği yerde, şâirlerin usulleri hilafına Şems, Şems-i Tebrizî isimlerini mahlas olarak kullandığı için, bu dîvâna Dîvân$\imath$ Şems veya Dîvân- Şems-i Tebrizî adı verilmiştir. Çok geniş bir hacme sahip olduğundan Dîvân-ı Kebîr de denilen eser, yukarıda belirttiğimiz gibi şiirlerde Şems ve Şems-i Tebrizî mahlasları kullanıldığından Külliyât-ı Şems ve Külliyât-ı Şems-i Tebrizî isimleriyle de bilinmektedir. Mevlânâ şiirlerinde mahlas olarak sıkça kullandığı Şems ve Şems-i Tebrizî isimlerinin yanında Hâmûş kelimesi ile Selahaddîn-i Zerkûb ve Hüsameddîn Çelebi'nin isimlerini de mahlas olarak kullanmıştır. Ancak bu mahlasların çoğunun hitap mahiyetinde olduğu dikkatlerden kaçmamaktadır. Mevlânâ'nın Şems ile olan ilgisinden haberi olmayan kimseler, Şems'in Farsça yazılmış gazelleri olduğunu, bu çok değerli beyitleri onun yazdığını sanmışlardır. Halbuki Şems şâir olarak tanınmamaktadir.

Mevlânâ'nın çeşitli yer ve zamanlarda özellikle sema sırasında duygularını irticalen dile getirdiği şiirler, kâtib-i esrâr ismi verilen özel kâtipler tarafından anında kaydedilmiş ve söylendikleri aruz bahirlerine göre tertip edilmişlerdir. Böylece aruz vezninin yirmi bir farklı bahrinde söylenmiş ve her bahri, ayrı bir dîvânçe teşkil eden büyük bir dîvân meydana gelmiţtir. Dîvân'da yer alan şiirler, şiir söyleme veya yazma endişesi içinde olmadan söylenmiştir. Mevlânâ, günlük olaylardan etkilenerek çoğu kere vecd içinde sema ederken hissettiklerini vezin ve kâfiye potası içersinde söylemeye başlamıştır (Yazıcı 1994: 432). Nitekim Ritter, Dîvân'ın hakiki şevk ve heyecanın en saf ifadesi olmak ve edebî örneklere uyularak meydana getirilmesinden ziyade, his ve şahsî sergüzeştlerin yansıması oluşundan dolayı önemli olduğunu ifade etmiştir (1993: 56-57).

Cezbe ve coşku içinde kendinden geçmiş bir âşığın dudaklarından dökülen manzumelerden oluşan bir eser olan Dîvân-ı Kebîr, ağırlıklı olarak gazel formunda söylenmiş şiirlerden meydana gelmektedir. Tasavvufî şiir geleneğinde bir zirve olan bu gazeller, aynı zamanda gazel nazım şeklinin en güzel örneklerini oluşturmaktadır. Kullanılan imgeler 
bakımından güçlü şiirler içeren bu eser, özgünlük bakımından da dikkat çekmektedir. Özellikle Mevlânâ bu gazellerinde, Farsça gazel geleneğinin bir takipçisi olarak, klasik şiirde tekrarlanagelen sembol ve imgeleri tekrarlamakla yetinmemiş, bu imgeleri daha zengin çağrışımlarla kullanmış, hatta daha gönce kullanılmamış imgeler bulup söylemiştir. Burada dikkati çeken, Mevlânâ'nın bu özgünlüğü sergilerken şiir adına özel bir çaba sergilemeyip yaşadığı hâli dile getirmekten öte bir şey yapmamasıdır. İşte bu kendiliğinden oluş, onun şiirine ayrı bir güç ve çekicilik kazandırmıştır (Kırlangıç 2007: 222).

Mevlânâ'nın Dîvân'ındaki şiirleriyle Mesnevî̀ arasında üslûp, ifade, heyecan bakımından hiç mi hiç fark yoktur. Mesnevî̃ yi didaktik bir eser kabul edip Mevlânâ'nın asıl lirik şiirlerinin Dîvân'da mevcut olduğunu söyleyenler de vardır. Mesnevî, didaktik bir eser olmakla birlikte, bünyesinde yer yer lirizmin en kudretli ifadesini taşır. Dîvân'daki şiirlerin bir çoğu da didakdiktir, fakat Mevlânâ, inancında o kadar özlüdür ki inandırmak için söylediği sözlerde de lirizm ve didaktizmi âdeta bünyesinde yoğurur ve yok eder. Dîvân'daki bir çok gazellerde Mesnevî hikâyelerini özetleyen Mevlânâ, Mesnevĩ deki bahislerin birçoğuna yine Dîvân'da yer vermiţtir. Dîvân ve Mesnevî, hem uslûp, hem ifade, hem edâ, hem konu bakımindan aslında aynı olup bu iki eser arasında sadece tarz ve vezin farkı vardır (Gölpınarlı 1992: I/X).

Arap ve İran Edebiyatı'na hakkıyla vâkıf olan Mevlânâ'nın Dîvân-ı Kebîr'inde Farsça ve Arapça gazellerin yanında, Rumca ve Arapça mülemmalar da mevcuttur. Mülemmaların toplam sayısı 64'tür. Arapça gazelleri ise 91 adettir (Alp 1997: 5). Ayrıca Mevlânâ'nın Mesnevĩ sinde ve Dîvân'ında yer alan beyitlerde birçok Türkçe kelimeye rastlanıldığı gibi (M. Şerefeddin 1934: 111-155), Dîvân'da zaman zaman Türkçe ve Türkçe-Farsça karışık beyitler de bulunmaktadır9 (M. Şerefeddin 1934: 156-167; Mansuroğlu 1988). Bu şiirlerde Türkçe, başlı başına bir manzume çapına çıkamasa da, beyit seviyesine yükselen dağınık ifadeler

\footnotetext{
${ }^{9}$ M. Şerefeddin, Mevlânâ'ya ait olduğunu söylediği 17 tane Türkçe ve Türkçe-Farsça manzume neşretmiştir (1934: 156-67). Mecdut Mansuroğlu ise, M. Şerefeddin'in Mevlânâ'ya dil, sanat, eda ve konu bakımından uzak düşen bazı Türkçe beyitleri de Mevlânâ'nın olarak tanıttığını ileri sürmüş ve bunlardan sadece 10'unun Mevlânâ'nın olabileceğini ileri sürmüştür (1988: 208).
} 
hâlinde kendini göstermektedir (Akün 1994 : 393). Bunların Farsça şiirlerle çok az ortak noktalarının olduğu görülmektedir. Ekseriyetinin dünyevî eğlence ile ilgili olduğu izlenimi veren bu Türkçe şiirlerde, Mevlânâ'nın özel hayatına ait kullanımlar da vardır. Bazen bu şiirlerde, Ân yekî Turkî ki âyed gûyedem "Hey geymü sen?" (Bana her gelen Türk "hey iyi misin?" der) misraında olduğu gibi Türkçe unsurların alelâde bir ifadenin aktarımıyla sınırlı olduğu da görülmektedir. Bunun yanında neşeli bir tarzda aşkın ve şarabın zevkinden bahseden şiirler de vardır. Muhteva olarak dünyevî görülen bu şiirlerde, çeşitli deyimlere de yer verilmiştir. R̂̂zî nişest hâhem yalguz sinün katunda / Hem sen çagıı içer sen hem men kobuz çalar men (Bir gün senin yanında yalnız oturmak istiyorum; sen şarap içersin ben de kopuz çalarım) beytinde olduğu gibi. Bazı şiirlerde ise ya bir "Türk"e hitap edilmekte ya da bir "Türk"ten bahsedilmektedir. Meselâ Turk-i mâh-çehre (ay yüzlü Türk), Merâ yârist Turk-i ceng-cĥŷ̀ (Kavgacı bir Türk dostum vardır), Resîd Turkem (Türküm geldi) gibi. Mecdut Mansuroğlu bu şiirlerden ikisinin Türkler arasında dinî ve tasavvufî fikirleri yaymak amacıyla yazıldığını söylemektedir (Johanson 1993: 29-31).

Vasfi Mahir Kocatürk'ün de dikkat çektiği gibi, Mevlânâ'nın mülemma şeklinde söylenmiş şiirlerinde bulunan bazı mısraları vardır ki, ifade, ruh, ritim ve duygu yönünden, kendisinden önce bir benzeri görülmediği gibi, ondan sonra da yaklaşık bir asır yani Nesîmî'ye kadar benzerlerine rastlanmamaktadır. Özellikle,

Mâhest nemî-dânem hurşî̀ ruhet yâ ne

$B$ ayruluk odina nice cigerüm yane

matlalı mülemmaındaki Türkçe mısralar, kendi eserindeki İran şiirinin yüksek örneklerinden olan diğer mısralardan aşağı kalmayacak gerçek şiir edası taşımaktadır. Bunlardan:

Mecnûn bigi vâveylî oldum gene dîvâne

Fitnelü elâ gözler çün uyhudan uyane

misraları, zaman itibariyle olduğu gibi ruh itibariyle de, XVI. asırda Bâkî’nin temsil ettiği Türk Klasik şiirinin sanki ilk pırıltılarındandır (1970: 101). 
Mevlânâ'nın Türkçe şiirlerinden biri şu şekildedir (Mansuroğlu 1988: 214-15):

Eger geydür karmindas yoksa yavuz

Uzun yolda saña budur kulavuz

Çopanı berk dut kurtlar öküşdür

İsit binden kara kuzum kara kuz

Eger Tat sen eger Rûm sen eger Türk

Zebân-i bî-zebânân-râ biyâmû̀ $z^{10}$

Mevlânâ'nın Farsça-Türkçe mülemma bir gazelinin bazı beyitleri ise şöyledir (Cengiz 1985: 8-9):

Dânî ki min zi-'âlem yalguz seni sever min

Eger der berem neyâyî ender-gamet öler min

Men yâr-i bâ-vefâyem ber-men cefâ kulur sen

Ger to zi-men ne-porsî min hod seni sorar min

Rûzî nişeste hâhem yalguz sinün katunda

Hem min çakır içermin hem min teyiş biler min

Mâhî çü Şems-i Tebrîz gaybet numûd u goftâ

Ez-men diger ne-porsîd min söyledüm yazar min ${ }^{11}$

Mevlânâ gerek yaşadığı kültürel ortam gerekse içirisinde bulunduğu hâlet-i rûhiye ve vecd gereği eserlerini Farsça söylemiştir. Çünkü gönlünde bulunan o kabına sığmaz aşk coşkunluğunu ancak gelişmiş ve işlenmiş bir dil olan Farsça ile terennüm edebilirdi. Nitekim o Doğu Türkçesini biliyordu. Oğuz Türkçesini ise

\footnotetext{
${ }^{10}$ 1. Eğer, kardeş, iyi de, kötü de olsa, uzun yolda sana kılavuz budur. 2. Çobanı sıkı tut, kurtlar çoktur; işit benden kara esmerim, kara esmer. 3. Eğer Acemsen, Eğer Rumsan (ve) eğer Türksen (de), dilsizlerin dilini öğren (Mansuroğlu 1988: 214-15).

${ }^{11}$ 1. Bilirsin ki ben (bu) âlemde yalnız seni severim, eğer yanıma gelmezsen senin gamınla ölürüm. 2. Ben vefalı âşı̆̆ım (sen ise) bana cefa ediyorsun. Şayet sen beni (arayıp) sormazsan, ben kendim seni (arayıp) sorarım. 3. Bir gün senin yanında tek başıma oturmak isterim. Hem ben şarap içerim; hem de şarkı-türkü bilirim. 4. Tebrizli Şems gibi bir ay kayboldu ve dedi: Beni artık sormayın; ben söyledim, ben yazarım.
} 
Anadolu'da öğrenmişti. Oysa Oğuz Türkçesi, 'edebî dil' hüviyetini henüz o dönemde kazanamamıştı. Ancak yukarıda zikrettiğimiz gibi, içlerinde bulunduğu ve belli bir noktada muhatabı olan Türk halkına karşı da bigane kalmayıp ya mülemma şeklinde ya da beyte yayılmış şekilde Türkçe şiirler söylemekten de kendini alamamıştır. Edebî açıdan önemli olmayan bu şiirlerin, Johanson'un da belirttiği gibi, "yerel" bir konuşma biçiminin bir yazı dili olarak gelişmesine katkı sağladığı da yadsınamaz bir gerçektir (Demir 2007: 307).

Mevlânâ'nın bu manzum eserlerinin dışında Fîhi Mâ Fih, Mecâlis-i $S e b^{\prime} a$ ve Mektûbât isimli Farsça mensur eserleri de bulunmaktadır.

\section{Sultan Veled}

$\mathrm{Bu}$ dönemin önemli şâirlerinden olan Sultan Veled, Mevlânâ Celâleddîn-i Rûmî́nin büyük oğlu olup 623/1226 yılında bugün Karaman olarak bilinen Larende'de doğmuştur. İlk öğrenimini babasından alan Sultan Veled, erken yaşlarda babası ile birlikte dönemin ileri gelen âlimlerinin de bulunduğu çeşitli toplantılara katılmış ve katıldığı bu toplantılardan istifade etmiştir. Sadık bir mürit gibi babasına ve Şems-i Tebrîzî'ye hizmet etmiş; ilk kayboluşunda Şam'a giderek (1246) Şems-i Tebrîzî̀yi geri getirmiştir. Şems-i Tebrîzî'nin ölümünden sonra (1247) aynı saygıyı babasının halifeleri Selâhaddîn-i Zerkûb'a ve Hüsameddîn Çelebi'ye de göstermiş, babasının ölümü üzerine (1273) onun yerine geçmesi istenmişse de kabul etmemiş, bilakis Çelebi'ye tabi olmuştur. Hüsameddin Çelebi ölünce (1284) 1srarlara karşı koyamamış, postnişinliği kabul etmiş, ancak gerçek halifenin Kerimüddîn Bektemür olduğunu belirtmekten geri kalmadığı gibi, Bektemür'ün ölümüne kadar da (1291) ona gereken saygıyı göstermiştir. Sultân Veled post-nişin olduktan sonra babasının yolunu örgütlemeye çalışmıştır. Mevlevilik onun zamanında örgütlü bir tarikat haline gelmiş, gerek yapıtları, gerekse dört bir yana gönderdiği dervişleri ve halifeleriyle mevleviliğin yayılmasını sağlamıştır. Sultân Veled, 86 yaşında olduğu halde 712/1312 tarihinde vefat etmiştir.

Şiirlerinde Anadolu halkını aydınlatmak ve Mevlânâ'nın görüşlerini yayıp açıklamak ile büyüklüğünü telkin maksadını güden Sultan Veled, arada Türkçe şiirler söylemişse de eserlerinin büyük bir çoğunluğunu 
Farsça yazmıştır. Türkçe şiirleri Anadolu Türkçesinin eski örneklerinden sayılır. Tasavvuf esaslarını öğretme mahiyetinde olan Türkçe şiirlerinde aruz veznini ve daha ziyade mesnevî nazım şeklini kullanmıştır. Sultan Veled'in bu Türkçe şiirleri Gibb'in söylediği gibi Osmanlı Devleti'nin tesis edildiği sıralarda Batı Asya Türkçesine örnek teşkil etmesi bak1mindan ilginçtir. Bu şiirlerde kullanılan Türkçe kelimelerin ekseriyeti bugün unutulmuş, bir kısmı muhtemelen Osmanlı Türkçesinde hiç kullanılmamış, geri kalanı da belki hâlâ bazı ağızlarda varlığını sürdürmektedir. Didaktik mahiyette olup sade ve yumuşak bir üslûba sahip olan bu şiirlerde, özellikle amacından dolayı edebî bir zerafet yoktur. Ancak Türk tarzı ölçüye uygun olup kafiyeler oldukça isabetli oluşturulmuştur (Gibb 1999: 106).

Sultan Veled'in şiirlerindeki Türkçe, Mevlânâ'nınkiler gibi dağınık misra, beyit ve mülemmalardan ibaret kalmayıp sayısı 14'ü bulan gazelin başından sonuna kadar yer alabilecek bir duruma gelmiştir. Sultan Veled bununla da yetinmeyerek İbtidâ-nâme'sinin 76 beytiyle, Rebâbnâme'sinin 162 beyitlik bir bölümünü de Anadolu Türkçesiyle meydana getirmiştir. Gerek 10.000 beyitlik İbtidâ-nâme'sinde gerekse 8.124 beyitlik Rebâb-nâme'sinde Türkçeye hakim olamadığını bildiren sözlerinde onun aruzlu ifadede nasıl zorlandığı, bundan dolayı her ikisinde ara yerde yaptığı bu Türkçe çıkışlardan sonra söyleyeceklerini daha rahat anlatabilmek için tekrar Farsçaya döndüğü dikkat çekmektedir (Akün 1994: 393).

Sultan Veled'in özellikle Türkçe gazellerinde, Türk halk edebiyatında oldukça fazla kullanılan ve yer alan aliterasyonun varlığı dikkat çekmektedir. Şâir, bu usülü kullanmakla kendi şiirlerini hiç şüphesiz Türk halk şiirine yaklaştırmış, böylece halkın kendi şiirlerini kolayca benimsemelerine zemin hazırlamıştır. $\mathrm{Bu}$ da hiç şüphesiz Sultan Veled'in ortaçă̆ Anadolu'sunda meşhur olmasına vesile olmuştur (Fomkin 1994: 137-41). Sultan Veled'in Türkçe şiirlerinin esasını, Fomkin'in tespit ettiği gibi eski çağlardan gelen Türk şiir geleneği ile onun kendi estetik tasavvurları oluşturmuştur (bak. Fomkin 1994).

Sultan Veled'in söylemiş olduğu bu Türkçe şiirler, daha sonra geleceklerin bir nevi öncülüğünü yapmıştır (Akün 1994: 393). Nitekim aşa- 
ğıdaki beyitlerde yer alan ve klasik şâirlerin ortak kullanımı olan mazmunlar ve kavramlar sanki bunun delili gibidir:

Senün yüzün güneşdür yoksa aydur

Cânum aldı gözün daki ne eydür

Temâşâ çün berü gel kim göresin

Nite gözüm yaşı ırmak u çaydur

Ne okdur bu ne ok kim degdi senden

Benüm boyum sünüydi şimdi yaydur

Kaşlarun yâdur gözün oklar atar

Gönglüm ol oklarıçun oldı âmâç

Ol ne kaşdur ol ne gözdür cân alur

Ol ne boydur ol ne yüzdür ol ne saç

Sultan Veled'in Dîvân'ı ve mesnevîlerinde yer alan Türkçe manzumeleri (Sultan Veled 1341; Mansuroğlu 1958) ile Arapça şiirleri (Değirmençay 1997) yayımlanmıştır.

Sultan Veled'in tamamı Farsça olan eserleri şunlardır:

Sultân Veled'in Dîvân (Uzluk 1941)'1, kaside, gazel, kit'a, terci-bend, terkib-bend, musammat ve rubaîlerden oluşmaktadır. Rubaîler (Uzluk 1941: 559-616; Değirmençay 1996a) ise ayrı bir cüz halinde bulunmaktadır. Dîvân'da, Farsça 826 gazel, 32 kaside, 9 kıt'a, 10 terci-bend ve terkibbend, 23 musammat, 454 rubaî yanında Türkçe ve Arapça şiirler ile Rumca beyitler de vardır. Bunlar, 62 beyitte 8 Arapça manzume ve 3 rubaînin yanında, Farsça bir gazel içinde 3 beyit, ayrıca bir de FarsçaArapça mülemma şiir; 123 beyitte, 14 Türkçe manzume ve Farsça-Türkçe 13 beyitlik mülemma bir gazel; 21 Rumca beyit ile Farsça-Türkçe, FarsçaArapça ve Farsça-Rumca bir arada mülemma şiirlerdir (Değirmençay 1996: 52).

Dîvân'daki gazellerin çoğu, Mevlânâ'nın gazellerine nazire olarak yazılmıştır. Büyük bir edebî değeri olmayan bu eser, devrinin muhtelif devlet ricali için yazılmış olan ve çok defa beyitlerinin ilk harflerinin sıralanmasından, hakkında yazılmış olduğu şahsın adı çıkan manzumeleri sebebiyle tarih tetkikleri bakımından mühimdir (Yazıcı 1997: 30). 
Övgü ve mersiye mahiyetinde olanlar müstesna, bütün gazeller tasavvufî ve didaktik bir mahiyettedir. Bu gazellerin ve rubaîlerin en büyük özellikleri ifadenin hepsinde açık ve sâde oluşudur.

Sultân Veled'in ilk mesnevîsi olan İbtidâ-nâme (Sultan Veled 1315, 1976), Mevlânâ'nın hayatı ve Mevlânâ âşıklarının ilk inançlarını gösteren en eski ve doğru kaynak olması bakımından oldukça önemlidir. 1291 tarihinde yazılan mesnevîde 76 Türkçe, 180 Arapça ve 23 Rumca beyit de bulunmaktadir.

Sultan Veled, mesnevîsinin başında Mevlânâ'nın, Mesnevî́sinde geçmiş erenlerin kıssalarını zikrettiğini, onların kerametlerini ve makamlarını açıkladığını; onların kıssalarını anlatmaktan maksadının kendi kerametlerini ve makamların belirtmek olduğunu; kendisiyle dost ve gönüldaş olan Seyyid Burhaneddîn Muhakkık-1 Tirmizî, Tebrizli Şemseddin Muhammed, Konyalı Şeyh Selahaddin Feridun, Konyalı Çelebi Hüsameddin'in hâlleri ile kendi hâllerini, anlattığı hikâyelerle zikrettiğini belirttikten sonra, bazı kimselerin durumun doğruluğunu anlayacak, söylenen maksadı kavrayacak anlayış ve seziş kabiliyeti bulunmadığ1 için Mesnevî́de bildirilen kendisi ve kendisiyle gönülleri bir olan musahiplerinin ahvalinin okuyanlara ve dinleyenlere malum olsun, şüpheleri ortadan kalksın diye etraflıca anlattığını belirtir (Sultan Veled 1976: 1-2).

Rebâb-nâme (bak. Değirmençay 1996) 1301'de nesir ve nazım olarak kaleme almıştır. 8124 beyit olan mesnevîde 162 Türkçe, 36 Arapça ve 22 tane de Rumca beyit vardır. Sultan Veled, Rebâb-nâme'de, ögüülerden, Hakk'ın sırlarından yani Kur'ân ayetlerinden ve tarikatın gereği olan hususlardan bahsetmiştir. Bu bahisler içerisinde birçok âyet ve hadis iktibaslarında bulunulmuş ve mânâları geniş açıklamalarla ifade edilmiştir. Türkçe ve Arapça beyitlerde de aynı hususlar söylenmiş olup nispeten Türkçe beyitlerde, Arapça beyitlere oranla biraz daha fazla konu işlenmiş; ayrıca Mevlânâ'nın övgüsüne de yer verilmiştir.

Sultan Veled'in üçüncü ve son mesnevîsi İntihâânâme'dir. Eser, baştan sona Farsça olup diğer eserlerinde olduğu gibi Türkçe, Arapça ve Rumca beyitler yoktur (Değirmençay 1996: 54-55). İntihâ-nâme'de, tarikatın gereği olan şeylerle, vaaz ve nasihatlerin anlatılması yanında, Mevlevîlikle ilgili olarak Mevlânâ'nın Şems'e bağlanmadan önceki du- 
rumu, yaşantısı ve diğer özellikleri ile Şems'e bağlanması ve Şems'in, daha önce hiç sema yapmamış olan Mevlânâ'yı semaa başlatması; semaın, bütün müritler tarafından yapılması ve sema ile ilgili birtakım kısa anlatımlar da vardır (Değirmençay 1996a: 24).

Sultan Veled'in Maârif isminde Farsça mensur ve tasavvufî bir eseri dahi vardir.

\section{Nâsırî}

Bu dönem şâirlerinden olan Nâsırî́nin de bazı Türkçe şiirleriyle karşılaşmaktayız. Sivaslı olup Sultan Veled dervişlerinden Rükneddin el-Urmevî el-Konevî́nin oğlu olan Nâsırî, tarikat hakkında manzum bir kitap olmadığını görmüş ve Fütüvvetnâme (Gölpınarlı 1952: 181-203) isimli mesnevîsini 679/1280 tarihinde Farsça olarak yazmıştır. Aruzun "fâilâtün fâilâtün fâilün" kalıbıyla kaleme alınan ve 882 beyit olan mesnevîsini, Ahi Muhammed'e ithaf etmiştir (Ateş 1945: 118). Nâsırî́nin manzum mensur karışık olarak kaleme aldığı İşrâkât adında bir eseri daha vardır. Burada yer alan bazı hikâyeler Anadolu'da geçtiği için o dönem Anadolu'suna dair bazı bilgiler vermektedir. Ayrıca şâirin, Mesnevî ve Garîb-nâme'de de geçen "üzüm hikâyesi"ni anlatırken Türkçe iki beyte, başka bir latifesinde ise bir misraa yer vermesi, onun Farsçanın yanında Türkçe şiirler de söylediğini göstermektedir (Köprülü 1943: 446).

\section{Yûnus Emre}

Yaşadığ1 dönem konusunda farklı görüsşler olan, XIII. asrın ortaları ile XIV. asrın başlarında yaşadığı tahmin edilen, ilk Türkçe Dîvânı tertip eden, Risâletü'n-Nushiyye adında bir mesnevî kaleme alan Yûnus Emre'nin Türk edebiyatında müstesna bir yeri vardır. Türkçeyi çok iyi bir şekilde kullanan Yunus Emre, Oğuz Türkçesine dayalı Anadolu Türkçesinin müstakil bir yazı dili olarak kuruluşunda önemli bir rol oynamıştır (Korkmaz 1995: 363). Halkın konuşma dilini en canlı bir şekilde kullanmış, Türkçenin bir edebiyat ve kültür dili olmasında son derece önemli hizmette bulunmuştur (Timurtaş 1997: 236).

Yunus'un eserlerinde kullandığı dil sade, canlı bir konuşma diline yaslanmakla birlikte $\mathrm{O}$, halk tarafından anlaşılan Arapça ve Farsça keli- 
meleri kullanmaktan da çekinmemiştir. Bu onun şöhretinin geniş halk kitlelerine yayılmasını sağlamıştır.

Yunus Emre'nin Divan'ında (Tatçı 1990; Timurtaş 1989) yer alan gazellerinin konusu, hemen hemen tamamen din ve tasavvuf etrafinda odaklanmaktadır. O, Orta Asya'da Ahmed-i Yesevî ve dervişlerinin hikmetleriyle başlayan çı̆̆ırı, Anadolu'da devam ettirmiştir. Ancak bu devam, taklidî mahiyette olmamıştır. Çünkü Yunus hikmet geleneğini kendi kabiliyetiyle yoğurarak en üst düzeye çıkaran ve kendisinden sonra bir Yunus mektebinin oluşmasını sağlayan orijinal bir şâirdir (Tatçı 1990: I/71-72). Yunus, Orta Asya Türk tasavvuf geleneği ile tasavvuf felsefesini birleştirmiş yani Ahmed-i Yesevî ile İbnü'l-Arabî'nin düşüncelerini kendisinde bir araya getirmiş bir şahsiyettir (Yakıt 2002: 17). Bir şiirinde Mevlânâ Hüdâ-vendgâr bize nazar kılalı / Onun görklü nazarı gönlümüz aynası [oldu] diyerek Mevlânâ'nın manevî nazarı altında olduğunu belirten Yunus Emre, bazı yazarlara göre "Mesnevî̀yi ve Dîvân-ı Kebîr'i okumuş, onlardan bir çok mazmûnları, kendince tasarruf etmiş, Mevlânâ'nın tesiri altında kalmış, hatta onun insanî görüşünü Türkçede dile getirmiş bir şâirdir." Bazılarına göre de "Daha önce İbn Arabî ve Mevlânâ'da vahdet-i vücûd ve buna bağll olarak diğer tasavoufî mefhumlar, en geniş ve apaçı ifadesini bulmuştu. Fakat Türkçede ilk defa Yunus bu mefhumları 'üryan' kılıyordu." Yine onun Türk edebiyatındaki yeri ve tesirleri üzerinde geniş bir çalışma yapan Köprülü'nün ifadesiyle "O, Muhyiddin-i Arabî ve şakirtleriyle Celaleddin-i Rumînin yaydı̆̆ı geniş ve serbest telakkîleri tamamıyla kendine maletmiş, rûhen mutasavorf, büyük ve çok samimî ve sanatkâr bir şahsiyetti" (Kılıç 2007: 79-80). Yunus Emre'nin "Çıkdum erik dalına anda yidüm üzümi / Bostan ıssı kakıyup dir ne yirsün kozumı" matlaıyla başlayan şiiri, diğer şiirlerinin aksine tamamen sembolik olarak kaleme alınmıştır. Seyr ü sülûka giren dervişlerin karşılaştıkları güçlüklerin sembolik olarak anlatıldığı bu şiire, bazı mutasavvıflar tarafından şerhler yazılmıştır (Pekolcay vd. 1991; Yakıt 2002; Tatc1 2005).

Yunus Emre'nin 707/1307 tarihinde kaleme aldığı Risâletü'n-nushiye (Tatçı 1990; Günay vd. 2004) isimli mesnevîsi, aruzun "fâilâtün fâilâtün fâilün" kalıbıyla yazılan manzum bir girişle başlar. Kısa bir mensur bölümden sonra, mefâîlün mefâîlün feûlün vezniyle yazılan mesnevînin asıl bölümleri gelmektedir. 600 beyitten oluşan mesnevînin giriş man- 
zumesinde Hz. "Âdem'in yaratılışı" ve "Anâsır-1 Erbaa (toprak, su, hava, ateş)" açıklandıktan sonra, mensur kısımda akıl, iman ve ilim makamları ele alınmıştır. Daha sonra "ruh ve akıl", "kibir ve kanaat", "buşu ve gazap", "sabır", "buhl ve haset" ile "gıybet ve bühtan" konuları sırasıyla şerh edilmiştir. Risâletü'n-nushiye'de tasavvufî ahlâk, ya da seyr ü sülûk denilen manevî yolculuk, insanın iç mücadelesi, kendini bilme ve bulma gayreti, bir toplum düzeninden hareketle daha doğrusu Anadolu Selçuklu Türk askerî teşkilatından ve sair sosyal hayatından mehazlar alınarak anlatılmıştır. Ele alınan mücerret dünya anlayışı, müşahhas örneklerle, hikâye diliyle ve nasihatçi bir anlayışla işlenmiştir (Tatçı 1990: III/1-18). Eserin diğer bir özelliği de İslâmiyetle birlikte Türk ruhunda meydana gelen değişikliği yansıtmasıdır. Nitekim eserde, dışa dönük, savaşçı, maddî kuvvete dayalı alp tipi'nin yerini; içe dönük, manevî olanın peşine giden veli tipi almıştır. Yunus bu eserinde adeta eski Türk akıncısını atından indirerek elinden kılıcını ve okunu almış ve onu kendi içinde sefere davet etmiştir (Günay vd. 2004: 92). Risâletü'nnushiyye, her ne kadar muhteva ve kurgu yönünden başarılı olsa da, nazım tekniği; yani işlenişi bakımından zayıf bir eserdir. Eserin türünün ilk örneklerinden biri olması ve Yunus'un mizacına uymamasından dolayı Yunus, mesnevîsinde ele aldığı konu itibariyle ön plana çıkmıştır. Nitekim Yunus Emre, mesnevîsinden ziyade divanındaki gazel ve ilahîleriyle şöhret bulmuş ve bir Yunus mektebinin doğmasına sebep olmuştur (Günay vd. 2004: 97-98).

\section{Dehhânî}

Bu dönemde yazmış olduğu Türkçe şiirlerle dikkati çeken şâirlerden biri de Dehhânî'dir. Dehhânî́nin hayatı hakkında bilgilerimiz çok sınırlıdır. Bugün için elimizde bulunan tek kasidesinden bildiğimiz, Horasan'dan Anadolu'ya geldiği ve sultandan tekrar oraya dönmek istediğidir. Dehhânî'yi ilim âlemine tanıtan M. Fuad Köprülü'nün tespitlerine göre şâir, III. Alâaddîn Keykubâd devrinde (1298-1302) Anadolu'ya gelmiş ve bu sultana intisap etmiştir. Onun sarayında bulunan Dehhânî, eğlence ve işret meclislerine de katılmıştır. Ayrıca bu sultanın isteği üzerine yirmi bin beyitlik Farsça bir Şeh-nâme kaleme almıştır (Köprülüzâde Mehmed Fuad 1926; Köprülü 1986: 271, 337). Köprülü'den sonra Mecdut Mansuroğlu (1947: 4-5) ve Vasfi Mahir Kocatürk (1970: 170) de 
Dehhânî́nin III. Alâaddîn Keykubâd zamanında yaşadığını belirtmişlerdir. Devriyle ilgili bazı hususiyetleri bünyesinde barındıran söz konusu kasidesinde yer alan bazı telmihleri, Hikmet İlaydın farklı şekilde yorumlayarak onun I. Alâaddîn Keykubâd zamanında (1220-1237) yaşamış olabileceğini ileri sürmüştür (1974). Çetin Derdiyok da "Tematik Bir Bakış"la değerlendirdiği kasidesinde bu sultanın büyük ihtimalle I. Alâaddîn Keykubad olduğu sonucuna varmıştır (1994). Ömer Faruk Akün ise, bir manzumesindeki ipuçlarından hareket ederek onun 1361 tarihinde daha hayatta olduğu ve Anadolu'dan henüz ayrılmadığına dikkat çekmiştir (1994: 393). Günay Kut ise, Karaman Beyi Alâaddîn Ali (ö. 1398) zamanında yaşadığını belirtmektedir (2004: 354). Ancak Dehhânî'nin bilinen tek kasidesi, Mecmû'atü'n-nezâ'ir'e göre Ahmedî'nin şiirine (Canpolat 1982: 26-28), Câmi'u'n-nezâ'ir'e göre ise Şeyyâd Hamza'nın şiirine (vr. 434b) yazılan nazireler arasında gösterilmektedir. Bu da, nazire derleyicilerinin bu konuda yeterli dikkat göstermediklerini, dolayısıyla Dehhânî'nin XIV. asırda yaşadığına dair sonuçlara ihtiyatla yaklaşılması gerektiğini göstermektedir. Dehhânî'nin döneminin bazı hususiyetlerini bünyesinde barındıran kasidesindeki görüşler ve dönemin sultanı hakkında söylediği düşüncüler ise, onun Sultan I. Alâaddîn Keykubâd döneminde yaşadığını düşündürmektedir. Çünkü Horasan yöresinden Anadolu'ya olan sanatkar ve alim akımının, bu sultan döneminde oluşan huzur ve istikrardan dolayı yoğunlaştığı bilinmektedir (Kartal 2007: 473).

XV. asırda Ömer b. Mezîd'in Mecmû'atü'n-nezâ'ir'i (Canpolat 1982: 26-28, 32-33, 42, 54-55, 133-34) ile XVI. asırda Eğridirli Hac1 Kemâl'in Câmi'u'n-nezấir'i gibi önemli nazire mecmualarında şiirlerinin bulunması, Şeyhoğlu Mustafâ'nın Kenzü'l-küberâ'sında kendisinden bir şiir seçilmesi (Yavuz 1991: 144) ve Hatîboğlu'nun Hacı Bektaş-1 Velî́nin makalelerini tercüme ettiği Bahrü'l-hakâyık isimli eserinde adının bazı ünlü Türk şâirlerle anılması (Ertaylan 1960: 111 [metin]), Dehhânî'nin hem şöhretinin hem de etkisinin sonraki asırlarda devam ettiğini göstermektedir.

Fuad Köprülü, Dehhânî̀yi Anadolu'da "lâ-dinî klasik şiirin başlang1c1" olarak gösterir. Döneminde hemen bütün şâirlerin dinî-tasavvufî konulara yönelmesine karşılık Dehhânî́nin şiirleri bahar, gül, işret mec- 
lisleri gibi dünya zevklerini; hasret, arzu, heves, içli şikâyetler hâlinde dünyevî aşkın çeşitli tezahürlerini, hayatın geçiciliğini, bundan dolayı içinde bulunulan zamanı hakkıyla yaşamak gerektiğini yer yer şuh bir eda ile aksettirmiştir. Bunda Horasan'dan Anadolu'ya gelmeden önce büyük bir ihtimalle yine sarayda bulunması ve saray kültürünü yakinen bilmesi de etkili olmuştur. Çünkü o dönemlerde Orta Asya coğrafyasında hüküm süren Türk hanedanlarının gerek saraylarında gerekse saray etrafında vücut bulan edebiyata bakıldığı zaman, muhteva yönünden bu tarzda olduğu dikkat çekmektedir (Kartal 2007: 473).

Daha çok maddî hayatı dillendiren ve şekil mükemmeliyetini temsil eden din dışı klasik şiirimizin en başında yer alan Dehhâni'nin şiirleri, dil bakımından, Mevlânâ ve Sultan Veled'inkilere nazaran daha mütekâmildir. Renkli ve oldukça ilhamlı bir ruha sahip olan şâir, şiirlerini şekil güzelliği ile de süsleyerek mısralarında üstün bir ahenk oluşturmayı başarmıştır. Şiirleri arasında XIV. ve XV. asır klasik şiir edasını müjdeleyen güzel beyitler bulunmaktadır. Klasik İran şiirinde kalıplaşan ve klasik edebiyatımızda da kullanılan temsilî kelime ve mazmunları Türk şiirine ilk girdirenlerden biri olarak dikkat çekmektedir. Onunla birlikte, Türk edebiyatında muayyen bir estetik anlayışı, fikir ve sanat malzemesi, telmih sahaları ve şekil örnekleri olan klasik şiir başlamış olmaktadır. Dehhânî, maddî duygulu ve şekilci bir sanatkâr sıfatıyla, kendisinden sonra gelen XIV. asır şâirlerine, özellikle de Ahmedî’ye tabii bir tekamülle bağlanmaktadır. XV. asra kadar büyük şâirler arasında sayılan Dehhânî, bilhassa Ahmed Paşa'dan sonra, hem şiir dilinin hem de zevkin tekâmülüyle gölgede kalmış ve unutulmuştur (Kocatürk 1970: 109).

Dehhânî'nin bugüne kadar ele geçen şiirleri bir kaside ile altı gazelden ibaret olup toplam 79 beyittir. Biri özel kitaplığındaki bir mecmuada, diğeri Eğridirli Hacı Kemal'in Câmi'u'n-nezâ'ir adlı nazireler mecmuasında bulunan iki gazeliyle kasidesinin bazı parçaları ilk defa Fuad Köprülü tarafından yayımlanmış (Köprülüzâde Mehmed Fuad 1926), bunlara daha sonra Ömer bin Mezîd'in Mecmû'atü'n-nezấ'ir'inde bulunan dört gazel daha ilâve edilmiştir (Köprülüzâde Mehmed Fuad 1928). Mecdut Mansuroğlu, İstanbul Üniversitesi Kütüphanesi'ndeki bir nazireler mecmuasında yer alan üç gazeli, son beyitlerindeki "dehânı" keli- 
mesinin "Dehhânî" mahlasının vezin gereği değiştirilmiş şekli olabileceği düşüncesiyle Dehhânî'nin şiirleri arasına katmıştır (1942: 101-4). Ancak daha sonra bunun isabetsizliği Köprülü tarafından ortaya konmasına (1943: 396 [dipnot 1]) rağmen, Mecdut Mansuroğlu bu üç gazeli Dehhânî́nin diğer şiirleriyle birlikte ayrıca neşretmiştir (1947). Bu üç gazelden birinin Hikmet İlaydın'ın "tahmin" kayd-1 ihtiyatıyla ifade ettiği, M. Fatih Köksal'ın ise doğruluğunu teyid ettiği gibi XV. asır şâirlerinden Resmî'ye, diğer ikisinin ise XVI. asır âlim ve şâirlerinden Kemalpaşazâde'ye ait olduğu tespit edilmiştir (İlaydın 1978; Köksal 2005). Hoca Dehhânî̀ye ait olduğu bilinen bütün şiirler bazı filolojik düzeltmeler, bir indeks-sözlük ve orijinal nüshasının fotokopisiyle birlikte Hikmet İlaydın tarafından yayımlanmıştır (1978). Günay Kut, Dehhânî'nin bu yedi şiirine bir şiir daha ilâve etmiştir (Kut 1988).

Dehhânî'nin, Firdevsî̀nin Şeh-nâme'si biçiminde bir şeh-nâme yazması için Sultan Alâaddîn Keykubâd'dan emir aldığ XIV. asır Anadolu şâirlerinden Yarcânî'nin Karaman Oğulları Şâh-nâmesi'nde kayıtlıdır. Dehhânî, bu emir üzerine 20.000 beyitlik Farsça bir Şelçuklu Şâh-nâme'si yazmıştır. Fakat ne yazık ki bu eser bugün ortada yoktur.

\section{KAYNAKÇA}

Ahmet Eflâkî (1989), Âriflerin Menkıbeleri I-II, (Çev.: Tahsin Yazıcı), İstanbul: MEB Yay.

Akkaya, Şükrü (1954), Kitâb-ı Melik Dânişmend Gazi: Eine Türkische Historischer Heldenroman aus der Mitte des 13. Jahrhunderts, Ankara.

Akün, Ömer Faruk (1994), “Divan Edebiyatı,, mad., DİA, 9: 389-427.

Alî Şîr Nevâî (1323), Mecâlisü'n-nefâis, Der-Tezkire-i Şu'arâ-i Karn-i Nohum Hicrî, Te'lîf: Mîr Nizâmuddîn Alî Şîr Nevâ'î, (Be-Sa'y u İhtimâm-i Alî Asgar Hikmet), Tehrân.

Alp, Faruk (1997), Dîvân-ı Keb̂̂r Nüshaları [Tavsif - Mukayese - İndeks], Konya: Selçuk Üniversitesi, Yüksek Lisans Tezi.

Alpay, Selahattin (1986), Fütûhât-ı Mekkiyye, İstanbul: Şakir Hoca Kitabevi. Anbarcığlu, Meliha Ülker (1990), Mevlânâ, Fîhi Mâfih, İstanbul: MEB Yay. Anbarcıoğlu, Meliha (1991), Sultan Veled, Mâ̂rif, İstanbul: MEB Yay. Arat, Reşid Rahmeti (1979), Kutadgu Bilig I, Tıpkıçekimle Yapılmış İkinci Baskı, Ankara: TDK Yay. 
Arat, Reşid Rahmeti (1988) Yusuf Has Hâcib Kutadgu Bilig, (Çeviri), Ankara: TTK Yay.

Ateş, Ahmed (1945), “Hicrî VI-VIII. (XII-XIV.) Asırlarda Anadolu'da Farsça Eserler", Türkiyat Mecmuası, VII-VIII, Cüz: II: 94-135.

Ateş, Ahmed (1952), "Konya Kütüphanelerinde Bulunan Yazmalar", Türk Tarih Kurumu Belleten, 61: 49-130.

Ateş, Ahmed (1959), "Anadolu'nun Unutulmuş Bir Şâiri: Sayf al-Dîn Muhammed al-Fargânî", Belleten, XXIII: 415-25.

Ateş, Ahmed (1968), İstanbul Kütüphanelerinde Farsça Manzum Eserler I [Üniversite ve Nuruosmaniye Kütüphaneleri], İstanbul: Millî Eğitim Basımevi.

Ateş, Ahmed (1997), "Muhyi-d-din Arabî" mad., İslâm Ansiklopedisi, 8: 53355.

Baykara, Tuncer (2006), “Türkiye Selçuklularında Şehir/Kent ve Şehirliler/Kentliler", Anadolu Selçukluları ve Beylikler Dönemi Uygarlı̆̆ı, c. I, Ankara: Kültür ve Turizm Bakanlığı, s. 275-291.

Bayram, Mikâil (1981), Anadolu'da Telif Edilen İlk Eser: Keşfu'l-akabe, İbnu'lKemal İlyas b. Ahmed, Konya.

Bayram, Mikâil (1993), Şeyh Evhadü'd-dîn Hâmid el-Kirmânî ve Evhadiyye Tarikatı, Konya.

Bayram, Mikâil (1994), Fatma Bacı ve Bacıyân-ı Rûm (Anadolu Bacıları Teşkilâtı), Konya.

Bayram, Mikâil (1996), Ahi Evren (Şeyh Nasîrü'd-din Mahmud Al-Hoyi) İmânın Boyutları (Metâli'iül-îmân), [Konya].

Bayram, Mikâil (2001), "Anadolu Selçukluları'nda Devlet Yapısının Şekillenmesi", Cogito, 21, s. 61-72.

Bayram, Mikâil (2001a), Tarihin Işığında Nasreddin Hoca ve Ahi Evren, İstanbul.

Bayram, Mikâil (2001b), Tarihin Işı̆̆ında Nasreddin Hoca ve Ahi Evren, İstanbul.

Bayram, Mikâil (2003), Türkiye Selçukluları Üzerine Araştırmalar, Konya: Kömen Yay.

Bayram, Mikâil (2004), Destursuz Bağdan Üzüm Yiyenler, Konya: Kömen Yay.

Bayram, Mikâil (2005), Şeyh Evhadü'd-dîn Hâmid el-Kirmânî ve Menâkıb-nâmesi, İstanbul: Kardelen Yay.

Buluç, Sadettin (1955), "Eski Bir Türk Dili Yadigârı Behcetü'l-hadâ'ık fîMev'izeti'l-halâ'ik", TDED, 6: 119-31. 
Buluç, Sadettin (1956), "Behcetü'l-hadâ'ık fî-Mev'ızeti'l-halâ'ik'den Örnekler", TDED, 7/ 1-2: 16-37.

Buluç, Sadettin (1988), “Behcetü'l-hadâ'ık fî-Mev'izeti'l-halâ'ik'ten Derlenmiş Koşuklar", TDAY-Belleten 1963: 161-201.

Caferoğlu, A. (1972), "İlk Anadolu Vatan Kültürü Kurucuları", Türkiyat Mecmuası, XVII 1972: 1-12.

Can, Şefik (1990), Hz. Mevlânâ'ın Rubaileri I, İstanbul: KB Yay.

Can, Şefik (1991), Hz. Mevlânâ'ın Rubaileri II, İstanbul: KB Yay.

Can, Şefik (2003), Meolânâ, Hayatı-Şahsiyeti-Fikirleri, İstanbul: Ötüken.

Canpolat, Mustafa (1982), 'Ömer bin Mezîd Mecmû'atü'n-nezâ'ir, Ankara: TDK Yay.

Canpolat, Mustafa (1989), “Behcetü'l-hadâ' $k$ 'ın Dili Üzerine”, TDAY - Belleten 1967: 165-75.

Çelebioğlu, Âmil (1978), “XIII - XV (ilk yarısı). Yüzyıl Mesnevilerinde Mevlânâ Tesiri", Mevlânâ ve Yaşama Sevinci, (Hzr. Feyzi Halıcı), Ankara: 99-133.

Çiftçi, Hasan (2002), Klâsik Fars Edebiyatında Hiciv ve Sosyal Eleştiri, Ankara: KB Yay.

Dâvud İbrâhimî (1995), "Enîsü’l-kulûb" mad., TDV İslâm Ansiklopedisi, 11: 242-43.

Değirmençay, Veyis (1996), Sultan Veled ve Rebabnâme, Atatürk Üniversitesi, Sosyal Bilimler Enstitüsü, Doğu Dilleri ve Edebiyatları Anabilim Dalı, Erzurum [Basılmamış Doktora Tezi].

Değirmençay, Veyis (1996a), Sultan Veled Rubailer, Erzurum: AÜFEF Yay.

Değirmençay, Veyis (1997), Sultan Veled'in Arapça Şiirleri, Erzurum: AÜFEF Yay.

Değirmençay, Veyis (1997a), "İntihânâme Mesnevisinde Mevlânâ ve Mevlevîlikle İlgili Anlatımlar", Yedi İklim, 11/84: 53-8.

Demir, Nurettin (2007), "Batı Türk Yazı Dilinin Oluşumu", Türk Edebiyatı Tarihi, c. 1, İstanbul: Kültür ve Turizm Bakanlığı Yay.: 302-11

Derin, Adnan (1987), Tuhfe-i Mübârizî [Metin-Gramer Notları-Sözlük], Ankara: Gazi Üniversitesi, Yüksek Lisans Tezi.

Develi, Hayati (2006), Osmanlı'nın Dili, İstanbul: 3F Yayınevi.

Deyhîm, Muhammed (1367) Tezkire-i Şu'arâ-yi Âzerbaycan -Târîh-i Zindegî ve Âsâr-, Du Cild, Tebrîz. 
Düzen, İbrahim (1978), Muhammed b. Gazi al-Malatyavî ve Eseri Ravzat alUkul, II Cilt, Erzurum [Basılmamış Doçentlik Tezi].

Ertaylan, İsmail Hikmet (1949), “h. VII. (m. XIII) Asra Ait Çok Değerli Bir Türk Dili Yâdigârı: Behcetü'l-hadâ'ık fî Mev'zzeti'l-halâ'ik", TDED, III: 275-7.

Ertaylan, İsmail Hikmet (1960), Hatiboğlu, Bahrü'l-hakâyık, İstanbul: İ̈EF Yay.

Erzi, Adnan (1963), Gunyetü'l-kâtib ve Münyetü't-tâlib, Ankara.

Erzi, Adnan (1963a), Rüsûmü'r-resâ'il ve Nücûmü'l-fezâ'il, Ankara.

Fahrüddin Irâkî (1988), Lemâat [Pariltılar], (çev.: Saffet Yetkin): MEGSB Yay. Fazlığlu, İhsan (2006), “Anadolu Selçukluları ve Beylikler Dönemi Türk Felsefe-Bilim Tarihine Önsöz", Anadolu Selçukluları ve Beylikler Dönemi Uygarlı̆̆ı, c. I, Ankara: Kültür ve Turizm Bakanlığı, s. 413-428.

Fomkin, , M. S. (1994), “Sultan Veled (1226-1312)'in Şiir Sanatı ve Türk Şiir Geleneği", TDAY-Belleten 1991, Ankara: 137-48.

Furûzanfer, Bediu'z-zaman (1347), Menâkıbnâme-i Şeyh Evhadüddîn-i Kirmân̂ิ, Tehrân.

Furûzanfer, Bediu'z-zaman (1352), Bahâeddîn Veled, Ma'ârif I-II, Tehrân.

Furûzanfer, Bediu'z-zaman (1369), Kitâb-i Fîhi Mâfîh ez-Guftâri Mevlânâ Celâle'd-dîn Muhammed Meşhûr bâ-Mevlevî, Çâp-i Şeşom, Tehrân.

Furûzanfer, B. (1990), Mevlânâ Celaleddin, (Çeviren: Feridun Nafiz Uzluk), İstanbul: MEB Yay.

Gençosman, M. Nuri (1988), Mevlânâ'nın Rubaileri I-II [Tam Metin], İstanbul: MEGSB Yay.

Gölpınarlı, Abdülbaki (1945), Mevlânâ, Seçme Rubailer, İstanbul: MEB Yay.

Gölpınarlı, Abdülbaki (1952), “İslâm ve Türk İllerinde Fütüvvet Teşkilatı ve Kaynakları", İ.Ü. İktisat Fakültesi Mecmuası, XI: 1-354.

Gölpınarlı, Abdülbâki (1959), Mevlânâ Celâleddin, Fîhi Mâ Fîh, İstanbul: Remzi Kitabevi.

Gölpınarlı, Abdülbâki (1963), Mevlânâ Celaleddin Rûmî Mektuplar, İstanbul: İnk1lap ve Aka Kitabevleri.

Gölpınarlı, Abdulbâki (1963a), Mevlevî Âdâb ve Erkânı, İstanbul: İnkılâp ve Aka.

Gölpınarlı, Abdülbâki (1964), Rubâiler, İstanbul: Remzi Kitabevi.

Gölpınarlı, Abdülbâki (1965), Mecâlis-i Seb’a [Yedi Meclis], Konya: Konya Turizm Derneği Yay. 
Gölpınarlı, Abdülbâki (1976), Sultan Veled, İbtidâ-nâme, Ankara: Konya Turizm Derneği Yay.

Gölpınarlı, Abdülbâki (1979), Tarih Boyunca İslâm Mezhepleri ve Şî̂lik, İstanbul: Der Yay.

Gölpınarlı, Abdülbâki (1981-1983-1984), Mesnevî Tercemesi ve Şerhi, I.-II. Cilt, III.- IV. Cilt, V.-VI. Cilt: İstanbul: İnkılâp ve Aka.

Gölpınarlı, Abdülbâki (1983), Mevlânâ'dan Sonra Mevlevîlik, İstanbul: İnkılâp ve Aka.

Gölpınarlı, Abdülbaki (1985), M. Celâleddin Rumî, Fîhi Mâ-Fîh ve Mecâlis-i Seba'dan Seçmeler, Ankara: KTB Yay.

Gölpınarlı, Abdülbâki (1985a), Mevlânâ Celâleddin, İstanbul: İnkılâp Kitabevi.

Gölpınarlı, Abdülbâki (1992), Yunus Emre ve Tasavouf, 2. Baskı, İstanbul: İnklâp Kitabevi.

Gölpınarlı, Abdülbâki (1992a), Alevî-Bektaşî Nefesleri, 2. Baskı, İstanbul: İnkılâp Kitabevi.

Gülşehrî (1957), Mantıku’t-tayr [Tıpkı Basım], (Önsözü Yazan: Agâh Sırrı Levend), Ankara: TDK Yay.

Günay Umay, Osman Horata (2004), Risâletü'n-nushiyye, Ankara: Akçağ Yay.

Hâce Alî̀-i Hârezmî (1376), Yûsuf u Züleyhâ (Türkî), (Mukaddime: M. Kerîmî), Zengân.

Hacı Bektaş-1 Velî (1959), Hazret-i Hünkâr Hacı Bektaş-ı Velĩnnin Vasiyetnâmesi, Kitâbü'l-fevâ'id, (nşr. İ.Ö.), İstanbul.

Hacı Bektaş-1 Velî (1989), Şerh-i Besmele, (Hzr.: Rüştü Şardağ), Ankara.

Hacı Bektaş Velî (1996), Makâlât, (Prof. Dr. Esad Coşan'ın Tenkidli Basımından Sadeleştiren: Hüseyin Özbay), Ankara: KB Yay.

Hacı Bektaş Velî (2004), Makâlât-ı Gaybiyye ve Kelimât-ı Ayniyye, (Çev.: Davut Duman), Ankara.

Haşim, Muhammed Mîrzâ (1333), Kitâb-i Fîhi Mâ Fih, Tehrân.

İbn Arabî (1405), el-Fütûhatü'l-mekkiyye, (tas. Osman Yahya-İbrahim Medkûr), Cilt: I-XIV, Kahire.

İbn Bibi [El-Hüseyin b. Muhammed b. Ali el-Ca'feri er-Rugadi] (1996), El Evamirü'l-ala'iye fi'l-umuri'l-ala'iye [Selçuk-name], (Çev.: Mürsel Öztürk), II Cilt, Ankara: KB Yay.

İlaydın, Hikmet (1974), "Anadolu'da Klasik Türk Şiirinin Başlangıcı”, Türk Dili, XXX/ 274-279: 765-74. 
İlaydın, Hikmet (1978), "Dehhânî'nin Şiirleri", Ömer Asım Aksoy Armă̆anı, Ankara: TDK Yay.: 136-76.

İz, Fahir (1995), Eski Türk Edebiyatında Nazm, I-II, Ankara: Akçağ Yay. Johanson, Lars (1993), "Rûmî and the Birth of Turkish Poetry", Journal of Turkology, 1/1: 23-37.

Kanar, Mehmet (1999), Rubaîler, Evhadüddîn-i Kirmânî, İstanbul: İnsan Yay.

Kâni'-i Tûsî (1358), Kelîle ve Dimne-i Manzûm, (be-Tashîh: Magali Tudova), Bunyâd-i Ferheng-i Îrân.

Kartal, Ahmet (1999), Osmanl Medeniyetini Besleyen Kültür Merkezleri (XI. Astrdan XVI. Asrm Sonuna Kadar Türk Edebiyatı ve Fars Edebiyatınm Münasebetleri), Gazi Üniversitesi Sosyal Bilimler Enstitüsü, Ankara [Basılmamış Doktora Tezi].

Kartal, Ahmet (2000), "Ali Şîr Nevâî'nin Mecâlisü'n-nefâis İsimli Tezkiresi ve XVI. Asırda Yapılan Farsça İki Tercümesi", Bilig, 13: 21-65.

Kartal, Ahmet (2001), "Karahanlı, Gazneli ve Selçuklu Saraylarındaki Edebî Faaliyetler Üzerine Düşünceler", Bilig, 17: 55-70.

Kartal, Ahmet (2001a), "Türk Yazı Dilinin Gelişme Çağları", Türk YurduTürkçeye Saygı Özel Sayısı, 162-163: 221-49.

Kartal, Ahmet (2002), "Anadolu'da Farsça Şiir Söyleyen Şairler (XI-XVI. Asırlar)" Türkler, 7: 682-695.

Kartal, Ahmet (2006), "Anadolu Selçukluları ve Beylikler Döneminde Şiir ve Şâirler", Anadolu Selçukluları ve Beylikler Dönemi Uygarlı̆̆̆, c. I, Ankara: Kültür ve Turizm Bakanlığı, s. 493-519.

Kartal, Ahmet (2007), "Anadolu'da Türk Edebiyatının Öncüleri", Türk Edebiyatı Tarihi, c. 1, İstanbul: Kültür ve Turizm Bakanlığı Yay.: 465-80.

Kartal, Ahmet (2007a), "Tarihî, Sosyo-Kültürel Bağlam", Türk Edebiyatı Tarihi, c. 1, İstanbul: Kültür ve Turizm Bakanlığı Yay.: 439-64.

K1lıç, Erol (1996), "el-Fütûhatü'l-mekkiyye" mad., TDV İslâm Ansiklopedisi, 13: 251-58.

Kılıç, Mahmut Erol (2007), Sûfî ve Şiir, İstanbul: İnsan Yay.

Kırlangıç, Hicabi (2007), "Mevlânâ'nın Şiir Anlayışı", Mevlânâ, Ankara: Kültür ve Turizm Bakanlığı Yay.: 219-25.

Kocatürk, Vasfi Mahir (1970), Türk Edebiyatı Tarihi, Ankara.

Koman, Mahmud Mes'ud (1955), "Tuhfe-i Mübârizî [Lübâbü'n-nuhab tercümesi], İ.Ü. Tıp Fakültesi Mecmuası, 18/3. 
Konuk, A. Avni (1990), Fusûsü’l-hikem Tercümesi ve Şerhi, Cilt: I-III, (Hzr.: M. Tahralı-S. Eraydın), İstanbul.

Konuk, Ahmed Avni (1994), Mevlânâ Celâleddîn Rûmî, Fîhi Mâ Fîh, (Yayına Hazırlayan: Selçuk Eraydın), İstanbul: İz Yay.

Korkmaz, Zeynep (1995), Türk Dili Üzerine Araştırmalar, Birinci Cilt, Ankara: TDK Yay.

Köksal, Hasan (2003), Battal Gazi Destanı, Ankara: Akçağ Yay.

Köksal, M. Fatih (2005), "Yanıltıcı Mahlaslar veya İbn-i Kemâl'in Ettikleri", Türk Edebiyatı, Şubat/376.

Köprülü, M. Fuad (1943), “Anadolu Selçukluları Tarihi'nin Yerli Kaynaklar1", TTK Belleten, VII/27: 379-522.

Köprülü, M. Fuad (1986), Türk Edebiyatı Tarihi, 4. Basım, İstanbul: Ötüken.

Köprülü, M. Fuad (2003), Osmanlı İmparatorluğunun Kuruluşu, 3. Baskı, Ankara: Akçă̆ Yay.

Köprülü, M. Fuad (2003a), Türk Edebiyatında İlk Mutasavvıflar, 9. Bask1, Ankara: Akçağ Yay.

Köprülüzâde Mehmed Fuad (1926), "Selçukiler Devrinde Anadolu Ţâirleri: Hoca Dehhânî", Hayat, 1/1: 4-5.

Köprülüzâde Mehmed Fuad (1926a), "Selçukîler Devrinde Anadolu Şâirleri II: Ahmed Fakîh", Türk Yurdu, IV /26: 286-95.

Köprülüzâde Mehmed Fuad (1928), "Selçukiler Devri Edebiyatı Hakkında Bazı Notlar", Hayat, IV /102: 488.

Kunt, İbrahim (1996), Mesnevî Sözlükleri ve 'Abdullatîf b. 'Abdullâh'ın Letâifu'llugat'ı, Selçuk Üniversitesi, Sosyal Bilimler Enstitüsü, Doğu Dilleri ve Edebiyatları Anabilim Dalı, Fars Dili ve Edebiyatı Bilim Dalı, Konya [Basılmamış Yüksek Lisans Tezi].

Kut, Günay (1988), "Yazmalar Arasında II", Osmanlı Araştırmaları, VII-VIII: 181-95.

Kut, Günay (2004), "Erken Dönem Nazım (XIII-XIV. Yüzyıl)", Türk Dünyası Edebiyat Tarihi, Ankara: AKM Yay.: 304-564.

Mansuroğlu, Mecdut (1942), “Anadolu Metinleri XIII. Asır II: Dehani” Türkiyat Mecmuası, VII-VIII: 101-104.

Mansuroğlu, Mecdut (1947), Anadolu Türkçesi (XIII. Asır) Dehhani ve Manzumeleri, İstanbul: İ̈EF Türk Dili ve Edebiyatı Mezunları Cemiyeti Yay.

Mansuroğlu, Mecdut (1950), "Anadolu'da Türk Yazı Dilinin Başlama ve Gelişmesi", Türk Dili ve Edebiyatı Dergisi, 4, İstanbul, s. 215-229. 
Mansuroğlu, Mecdut (1958), Sultan Veled'in Türkçe Manzumeleri, İstanbul: İÜEF Yay.

Mansuroğlu, Mecdut (1988), "Mevlânâ Celâleddin Rumî'de Türkçe Beyit ve İbareler", TDAY-Belleten 1954: 207-20.

Mazıoğlu, Hasibe (1972), "Selçuklular Devrinde Anadolu'da Türk Edebiyatının Başlaması ve Türkçe Yazan Şairler", Malazgirt Armağanı, Ankara: TTK Yay.: 297-316.

Mélikoff, Irène (1960), La Geste de Melik Dânişmend: Etude Crituque du Dâniţmendnâme, Tome I: Introduction et Traduction, Paris; Tome II: Edition Critique, Paris.

Mercan, İsmail Hakkı (1989), Menâkıb-nâme-i Şeyh Evhadeddîn Kirmânî, Kayseri: Erciyes Üniversitesi, Yüksek Lisans Tezi.

Mevlânâ (1335), Mektûbât-i Mevlânâ Celâle'd-dîn-i Rûmî, Önsöz ve Ekler: Yûsuf Cemşîd Purgulâm Huseyn Emîn, Tehrân.

Mevlânâ, Mevlânâ Celâleddîn Muhammed-i Mevlevi-yi Rûmî (1345), Kulliyât-i Dîvân-i Şems-i Tebrîzî [be-

inzimâm: Seyri der-Dîvân-i Şems be-kalem-i Alî Deştî - Şerh-i Hâl-i Mevlevî bekalem-i Bedîuzzamân Furûzanfer], Çâp-i sevvum, Tehrân.

Mevlânâ (1370), Mesnevi-yi Ma'nevî, Te'lîf: Celâleddîn Muhammed bin Muhammed bin el-Huseyn el-Belhî er-

Rûmî, (Hzr. Reynold A. Nicholson), Çâp-i Heftum, Si Cild, Tehrân.

Mevlânâ (1925-1940), Mesnevi-yi Ma'nevî, Te'lîf: Celâleddîn Muhammed bin Muhammed bin el-Huseyn el-Belhî sümme er-Rûmî, (Hzr. Reynold A. Nicholson), Heşt Cild, Leiden.

Mevlânâ (1937), Mevlânânın Mektupları, Mukaddime: Veled İzbudak, Önsöz: Nafiz Uzluk, Düzelten: Ahmed Remzi Akyürek, İstanbul.

Mevlânâ (1988), Mesnevî, (Çev.: Veled İzbudak, Gözden Geçiren: Abdülbaki Gölpınarlı), 6 cilt, İstanbul: MEB Yay.

Mevlânâ Celâleddin (1992), Dîvân-ı Kebîr, (Çev.: Abdülbaki Gölpınarlı), 7 Cilt, KB Yay.

Mevlânâ Celâleddîn-i Rûmî (1312), Rübâ'iyyât, İstanbul: Ahter Matbaası.

Mevlânâ Calâleddîn-i Rûmî (1993), MESNEVÎ (Faksimile Basım), Ankara: KB Yay.

Miftâh, İlhâme - Velî Vehhâb (1374), Nigâhî be-Revend-i Nufûz ve Gosteriş-i Zebân ve Edeb-i Fârsî der- Turkiye, Tehrân. 
M. Şerefeddin (1934), "Mevlânâ'da Türkçe Kelimeler ve Türkçe Şiirler", Türkiyat Mecmuast, IV: 111-68.

Ocak, Ahmet Yaşar (1992), "Battâl Gazi (ö. 122/740 [?])", mad. TDV İslâm Ansiklopedisi, 5: 204-5

Ocak, Ahmet Yaşar (2006), "Türkiye Selçukluları ve İslâm (Genel Bakış)", Anadolu Selçukluları ve Beylikler Dönemi Uygarlı̆̆l, c. I, Ankara: Kültür ve Turizm Bakanlığı Yay.: 443-457.

Ocak, Ahmet Yaşar (2006a), "XIII.-XIV. Yüzy1llarda Anadolu Şehirlerinde Dini-Soayal Hayat (Selçuklulardan Osmanlılara Genel Bir Bakış)", Anadolu Selçukluları ve Beylikler Dönemi Uygarlı̆̆l, c. I, Ankara: Kültür ve Turizm Bakanlığı Yay.: 249-263.

Ocak, Ahmet Yaşar (2006b), "Selçuklular ve Beylikler Devrinde Tasavvuf", Anadolu Selçukluları ve Beylikler Dönemi Uygarlı̆̆ı, c. I, Ankara: Kültür ve Turizm Bakanlığı Yay.: 429-39.

Ocak, Ahmet Yaşar (2007), "Mevlana Önce Kendi Zaman ve Zemininin İnsanıdır Yahut Mevlana'yı Doğru Anlamak Üzerine", Mevlana, Ankara: Kültür ve Turizm Bakanlığı Yay.: 15-37.

Özaydın, Abdülkerim (1993), "Dânişmendliler" mad., TDV İslâm Ansiklopedisi, 8: 469-74.

Özaydın, Abdülkerim (1993a), "Dânişmend Gazi (ö. 477/1085[?])" mad., TDV İslâm Ansiklopedisi, 8:

Özel, Ahmet (1990), Hanefi Fıkıh Âlimleri, Ankara: Türkiye Diyanet Vakfı Yay.

Öztekin, Nezahat (1978), Mevlânâ'nın Mesnevi'sindeki Hikâyelerin XII XV. Yüzyıl Andolu Mesnevilerine Etkisi, İzmir.

Pekolcay, Necla-Emine Sevim (1991), Yunus Emre Şerhleri, Ankara: KB Yay.

Râvendî, Necmüddîn Ebûbekr Muhammed bin Alî (1333), Râhatu's-sudûr (be-Tashîh: Muhammed İkbâl), Tehrân [Ofset ez-Çâp-i 1921 Leiden].

Râvendî, Muhammed b. Ali b. Süleyman er-Râvendî (1999), Râhat-üs-sudûr ve Âyet-üs-sürûr [Gönüllerin Rahatı ve Sevinç Alâmeti], 2 cilt, (Muhammed İkbal'in 1921'de G.M.S., H'de bastırdığı Farsça metinden Türkçeye çeviren AHMED ATEŞ), 2. Baskı, Ankara: TTK Yay.

Ritter, H. (1997), “Celâleddîn Rûmî” mad., İslâm Ansiklopedisi, 3: 53-59.

Riyâhî, Muhammed Emîn (1352), Mukaddime ber-Mirsâdü'l-ibâd-i Necm-i Râzî, Bungah-i Tercume ve Neşr-i Kitâb, Tehrân. 
Riyâhî, Muhammed Emîn (1369), Zebân u Edeb-i Fârisî der-Kalem-rov-i Osmânî, Çâp-i Evvel, Tehrân.

Riyâhî, Muhammed Emîn (1995), Osmanlı Topraklarında Fars Dili ve Edebiyatı, (Türkçesi: Mehmet Kanar), İstanbul: İnsan Yay.

Sadeddin Nüzhet - Mehmed Ferîd (1926), Konya Vilâyeti Halkiyyât ve Harsiyyâtı, Konya: Vilâyet Matbaası.

Safâ, Zebîhullah (2002), İran Edebiyatı Tarihi, (Çev.: Hasan Almaz), Cilt I, Ankara: Nüsha Yay.

Semerkandî, Ahmed Nizâmî Arûzi-yi Semerkandî (1368), Çehâr Makâle, (beSa'y u İhtimâm u Tashîh-i Allâme Muhammed Kazvînî), Tehrân.

Seyf-i Fergânî (1364), Dîvân-ı Seyf-i Fergânî, (nşr. Zebîhullah Safâ), Çâp-i Devvom, Tehrân.

Seyyid Burhânüddîn Muhakkık-i Tirmizî (1972), Máârif, (Çev.: Abdülbaki Gölpınarlı), Ankara.

Seyyid Burhânüddîn Muhakkık-i Tirmizî (1995), Ma'ârif, (Terc.: Ali Rıza Karabulut), Ankara.

Sipehsâlâr, Feridûn b. Ahmed-i Sipehsâlâr (1325), Zindegîn-nâme-i Mevlânâ Celâleddîn-i Mevlevî, (nşr.: Sa'îd-i Nefîsî), Tehrân.

Sipehsâlâr (1331), Menâkıb-ı Hazret-i Mevlânâ Celâlüddîn-i Rûmî, (terc.: Avni Konuk), İstanbul.

Sipehsâlâr (1977), Mevlânâ ve Etrafindakiler, (Çev.: Tahsin Yazıcı), İstanbul.

Subhânî, Tevfîk H. (1371), Mektûbât, Tehrân.

Sultan Veled, Behâe'd-dîn Mevlânâ Celâle'd-dîn Muhammed bin Huseyn-i Belhî (1315), Veled-nâme [Mesnevi-yi Veledî], (Bâ-Tashîh u Mukaddimei Celâl-i Humâî), Tehrân.

Sultan Veled (1341), Dîvân-ı Türkî̀-i Sultân Veled, (Câmi'î ve Muhaşşîsi: Kastamonu Meb'ûsu Veled Çelebi, Musahhihi: Kilisli Muallim Rifat), İstanbul.

Sultan Veled (1976), İbtidâ-nâme, (nşr. Abdülbâki Gölpınarlı), Ankara: Konya Turizm Derneği Yay.

Sühreverdî (1988), Nur Heykelleri, (Çev.: Saffet Yetkin), İstanbul: MEGSB Yay.

Şems-i Tebrîzî (1369), Makâlât, (nşr.: Ahmed-i Hoş-nuvîs), Tehrân.

Şems-i Tebrîzî (1974-1975), Konuşmalar "Makâlât", 2 Cilt, (Çev.: M. Nuri Gençosman), İstanbul. 
Şentürk, Ahmet Atillâ-Ahmet Kartal (2007), Eski Türk Edebiyatı Tarihi, İstanbul: Dergâh Yay.

Şeyh Fahruddîn İbrâhîm-i Hemedânî (1373), Külliyât-i Dîvân [Kasâyid, Gazeliyyât, Terci'iyyât, Terkîbât, Mukatte'ât, Musellesât, 'Uşşâk-nâme yâa Deh-nâme, Rubâ'iyyât, Leme'ât ve İstilâhât-i 'İrfâni-yi 'İâkkî], (Mukaddime-i Sa'îd-i Nefîsî), Tehrân.

Tatçı, Mustafa (1990), Yunus Emre Divanı I [İnceleme], II [Tenkitli Metin], III [Risâletü'n-nushiyye - Tenkitli Metin], Ankara: KB Yay.

Tatc1, Mustafa (2005), Yûnus Emre Külliyâtı: V Yûnus Emre Şerhleri, İstanbul: MEB Yay.

Tekindağ, M. C. Şehabeddin (1971), “İzzet Koyunoğlu Kütüphânesinde Bulunan Türkçe Yazmalar Üzerinde Çalışmalar I", TM, XVI: 133-62.

Terbiyet, Muhammed Ali (1314), Dânişmendân-i Âzerbaycan, Çâp-i Evvel, Tehrân.

Tevfîk, H. Subhânî (1365), Mecâlis-i Seb’a, Tehrân.

Tezcan, Semih (1994), "Anadolu Türk Yazınının Başlangıç Bir Yazar ve Çarhnâme'nin Tarihlendirilmesi Üzerine", Türk Dilleri Araştırmalarl, 4: 7588.

Timurtaş, Faruk K. (1989), Yunus Emre Divânı, Ankara: KB Yay.

Timurtaş, Faruk K. (1990), Tarih İçinde Türk Edebiyatı, İkinci Baskı, İstanbul: Boğaziçi Yay.

Timurtaş, Faruk K. (1997), Makaleler [Dil ve Edebiyat Incelemeleri], (Hzr. Mustafa Özkan), Ankara: TDK Yay.

Turan, Osman (1988), Türkiye Selçukluları Hakkında Resmî Vesikalar (Metin, Tercüme ve Araştırmalar), İkinci Baskı, Ankara: Atatürk Kültür, Dil ve Tarih Kurumu Yay.

Turan, Osman (1993), “Keyhusrev I ( ? - 1211)" mad., İslâm Ansiklopedisi, 6: 613-20.

Turan, Osman (1993a), “Keykâvus I, İzzeddîn ( ? - 1220)” mad., İslâm Ansiklopedisi, IX: 631-42.

Turan, Osman (1993b), “Keykubad I ( ? - 1237)” mad., İslâm Ansiklopedisi, VI: 646-61.

Turan, Osman (1998), Selçuklular Târihi ve Türk-İslâm Medeniyeti, 7. Baskı, İstanbul: Boğaziçi Yay.

Turan, Osman (2002), Selçuklular Zamanında Türkiye-Siyasî Tarih Alp Arslan'dan Osman Gazi'ye (1071-1328)-, 7. Baskı, İstanbul: Boğaziçi Yay. 
Turan, Osman (2006), “Ortaçağ Türkiyesi'nde Türkler ve Yerliler", Anadolu Selçukluları ve Beylikler Dönemi Uygarlığı, c. I, Ankara: Kültür ve Turizm Bakanlığı, s. 467-471.

Uzluk, Feridun Nafiz (1941), Divanı Sultan Veled, Ankara: Uzluk Basımevi.

Uzluk, Feridun Nafiz (1952), Anadolu Selçukluları Devleti Tarihi III, Ankara.

Uzunçarşılı, İsmail Hakkı; (1948), “XII. ve XIII. Asırlarda Anadolu'daki Fikir hareketleri ile İctimaî Müesseselere Bir Bakış", III. Türk Tarih Kongresi, Ankara 15-20 Kasim 1943, Kongreye Sunulan Tebliğler, Ankara: TTK Yay.: 287-306.

Van Den Bergh, S. (1997), "Sühreverdî" mad., İslâm Ansiklopedisi, 11: 88-90.

Yakıt, İsmail (2002), Yunus Emre'de Sembolizm Çektım Erik Dalına, Ankara: KB Yay.

Yınanç, Refet (1982), "Amasya Halifet Gazi Medresesi ve Vakıfları", Vakıflar Dergisi, XV: 5-22.

Yınanç, Mükrimin H. (1997), "Dânişmendliler" mad., İslâm Ansikloedisi, 3: 468-79.

Yûsufî, Gulâmhuseyn (1351), Letâ'ifu'l-hime, Tehrân: Bunyâd-i Ferheng-i Îrân. 